Carlos Donizete Ferreira da Silva

\title{
ANÁLISE DA GESTÃO DO CAPITAL DE RELACIONAMENTO: UM ESTUDO DE CASO EXPLORATÓRIO NA FÁBRICA DE MOTORES SÃO CARLOS.
}

\author{
Dissertação apresentada à Escola de \\ Engenharia de São Carlos da \\ Universidade de São Paulo, como parte \\ dos requisitos para a obtenção do Título \\ de Mestre em Engenharia de Produção.
}

Orientador: Prof. Dr. Marcelo Seido Nagano

São Carlos 
Dedico esse trabalho especialmente a uma pessoa, também especial, Sandra, minha esposa, pelo incentivo, compreensão, ajuda e paciência que teve durante todo o tempo em que dividi a minha vida entre a família e o estudo. A você Sandra, muito obrigado. 


\section{AGRADECIMENTOS}

Em especial ao meu orientador, Prof. Dr. Marcelo Seido Nagano, por acreditar no meu potencial, pela dedicação, pelo seu voto de confiança, profissionalismo e, principalmente pela amizade que demonstrou durante esse tempo que trabalhamos juntos no desenvolvimento desse trabalho.

A minha mãe Sebastiana Maria da Silva, em primeiro lugar por ter me apoiado a dar continuidade nos meus estudos quando completei minha qualificação, e em segundo lugar pela sua grande compreensão, por minha ausência durante este longo período dedicado aos estudos.

A meu pai Osvaldo Ferreira da Silva que mesmo a distância sempre demonstrou apoio a meus objetivos.

A todos os amigos que conheci e que de alguma forma contribuíram com sugestões e experiências para a realização desse trabalho.

A todos meus parentes e amigos de infância que mesmo a distância torciam pela realização deste sonho.

Sou grato ainda a todos os funcionários e professores da pós-graduação do Departamento de Engenharia de Produção da EESC-USP, pelo apoio e atenção dispensada. 


\section{RESUMO}

SILVA, C. D. F. (2006). Análise da gestão do capital de relacionamento: Um estudo de caso exploratório na Fábrica de Motores São Carlos. Dissertação (Mestrado) - Escola de Engenharia de São Carlos, Universidade de São Paulo, São Carlos, 2006.

Nos últimos anos, o Capital Intelectual vem assumindo importante posição de destaque junto as comunidades acadêmicas e empresarias, pois as formas mais modernas e eficazes de se mensurar os ativos intangíveis proporcionam para as organizações a gestão mais eficiente dos seus recursos. $\mathrm{Na}$ estrutura do Capital Intelectual existem ramificações de igual importância e representatividade, como o Capital de Relacionamento. Esta pesquisa tem como objetivo evidenciar a importância do gerenciamento do Capital de Relacionamento, mostrando como a concorrência proporcionada pela globalização levou as empresas a deixarem o tradicional sistema de produção em massa para buscarem novas alternativas na gestão dos seus recursos. Partindo desse cenário esta pesquisa utiliza-se como base os resultados obtidos na Fábrica de Motores São Carlos, abordando as características estruturais e os elementos que constituem o Capital de Relacionamento na empresa, retratando sua importância na formação de novas parcerias e modelos gerenciais a fim de obter vantagem competitiva sobre seus concorrentes.

Palavras-chave: Capital intelectual; Gestão do conhecimento; Capital de relacionamento. 


\section{ABSTRACT}

SILVA, C. D. F. (2006). Analysis of the management relationship capital: An exploratory case study in the São Carlos Motors Factory. Dissertation - Escola de Engenharia de São Carlos, Universidade de São Paulo, São Carlos, 2006.

At the last years the Intellectual Capital is taking over important position to the academic highlight communities and enterprises, because the most modern and effective forms to measure the intangible active, provide to the organizations the most efficient administration of their resources. In the structure of the Intellectual Capital, there is an equal importance and representatives ramifications, like the Relationship Capital. This research has as goal evidence, the Capital management importance of Relationship, showing as the competition provided by the globalization, has taken the companies let the traditional production system to seek new options in the administration of their resources. Starting by scenery, this research uses as base, the results obtained at the São Carlos Motors Factory, boarding the structural characteristics and the elements that constitute the Relationship Capital in the company, showing its importance in the new partnerships formation and management models in order to obtain competitive advantage about their competitors.

Keywords: Intellectual Capital; knowledge Management; Relationship Capital. 


\section{LISTA DE FIGURAS}

FIGURA 1 - Esquema do método de trabalho 5

FIGURA 2 - Processo de criação do conhecimento humano 12

FIGURA 3 - Evolução do conhecimento 13

FIGURA 4 - Quatro modos de conversão de conhecimento 18

FIGURA 5 - Estrutura do capital intelectual 35

FIGURA 6 - Navegador Skandia $\quad 39$

FIGURA 7 - Elementos de co-contratação $\quad 49$

FIGURA 8 - Macro e microoperações: consumidores e fornecedores 55

FIGURA 9 - Fábrica de Motores São Carlos $\quad 74$

FIGURA 10 - Estrutura organizacional da empresa $\quad 75$

FIGURA 11 - Fluxo de produção da planta São Carlos motores ZP4 - EA111 77

$\begin{array}{ll}\text { FIGURA } 12 \text { - Motores da planta São Carlos } & 79\end{array}$ 


\section{LISTA DE TABELAS}

TABELA 1 - Definições de capital intelectual 32

TABELA 2 - Principais elementos formadores do capital intelectual 34

TABELA 3 - Classificação das estruturas dos modelos que mensuram o capital intelectual 42

TABELA 4 - Níveis de relacionamento com clientes $\quad 61$

TABELA 5 - Porcentagem de cada questão para o primeiro turno 81

TABELA 6 - Porcentagem de cada questão para o segundo turno 83

TABELA 7 - Porcentagem de cada questão para o terceiro turno 84

TABELA 8 - Porcentagem de cada questão para os mensalistas 85

TABELA 9 - Porcentagem de cada questão no total de $\begin{array}{ll}\text { funcionários respondentes } & 87\end{array}$

TABELA 10 - Comparação: primeiro e segundo turno 89

TABELA 11 - Comparação: primeiro e terceiro turno 91

TABELA 12 - Comparação: primeiro turno e mensalista 92

TABELA 13 - Comparação: segundo e terceiro turno 94

TABELA 14 - Comparação: segundo turno e mensalista 96

TABELA 15 - Comparação: terceiro turno e mensalista 98

TABELA 16 - Porcentagem de cada questão para os fornecedores 116 


\section{LISTA DE GRÁFICOS}

GRÁFICO 1 - Conhecimento 101

GRÁFICO 2 - Comprometimento 103

GRÁFICO 3 - Relacionamento 105

GRÁFICO 4 - Custo 107

GRÁFICO 5 - Responsabilidade $\quad 109$

GRÁFICO 6 - Informação 111

$\begin{array}{ll}\text { GRÁFICO } 7 \text { - Qualidade } & 113\end{array}$

GRÁFICO 8 - Total funcionários $\quad 115$

$\begin{array}{ll}\text { GRÁFICO } 9 \text { - Total Fornecedores } & 118\end{array}$ 


\section{SUMÁRIO}

RESUMO

ABSTRACT

LISTA DE FIGURAS vi

LISTA DE TABELAS vii

LISTA DE GRÁFICOS viii

1. INTRODUÇÃO 1

1.1 Apresentação 1

1.2 Problema da pesquisa 2

1.3 Objetivos 3

1.3.1 Justificativa 3

1.3.2 Método de pesquisa 5

$\begin{array}{lll}1.4 & \text { Estrutura do trabalho } & 6\end{array}$

2. GESTÃO DO CONHECIMENTO 8

2.1 Introdução 8

2.2 Conhecimento - conceitos e definições 9

2.2.1 Definições filosóficas, econômicas e contemporâneas 10

2.3 A evolução do conhecimento 11

2.3.1 Primeira, segunda e terceira onda do conhecimento 14

2.4 Classificação do conhecimento organizacional 16

2.4.1 Conhecimento tático 16

2.4.2 Conhecimento explícito 16

2.4.3 A interação dos conhecimentos tácitos e explícitos 17

2.5 A criação do conhecimento organizacional 19

2.6 Aprendizagem organizacional 20

$\begin{array}{lll}2.7 & \text { A organização que aprende } & 22\end{array}$

2.8 Memória organizacional 24

2.9 Cultura organizacional 25

2.10 Mapeamento de competências e conhecimento 26

2.11 Gestão do conhecimento: a nova realidade 28 
3. CAPITAL INTELECTUAL 29

3.1 Introdução 29

3.2 Ativos intangíveis 30

3.3 Definições de capital intelectual 32

3.4 Elementos e estrutura do capital intelectual 33

3.4.1 Capital humano 35

3.4.2 Capital estrutural 36

3.5 Métodos de mensurar o capital intelectual 38

3.6 Gestão do capital intelectual 42

4. CAPITAL DE RELACIONAMENTO 45

4.1 Introdução 45

4.2 Capital de relacionamento 46

4.3 Tipos de relacionamento 48

4.4 Padrões de relacionamento 51

4.5 Relacionamento com clientes 52

4.6 Gestão do relacionamento dos clientes (CRM) 53

4.7 Relacionamento entre fornecedores e clientes internos 55

4.8 Relacionamento dos fornecedores com as montadoras 56

4.9 Marketing de relacionamento $\quad 59$

5. MÉTODO DE PESQUISA 62

5.1 Definições $\quad 62$

5.2 Tipo de pesquisa 63

$\begin{array}{lll}5.3 & \text { Protocolo de pesquisa } & 64\end{array}$

5.3.1 Visão geral do projeto de estudo de caso $\quad 64$

5.3.2 Pré-teste 65

$\begin{array}{lll}5.4 & \text { Coleta de dados } & 67\end{array}$

5.5 Hipóteses 71

$\begin{array}{lll}5.6 & \text { Estudo de Caso } & 71\end{array}$

5.6.1 Dados sobre a cidade de São Carlos (SP) 71

5.6.2 História da fundação da VW em São Carlos 72

5.6.3 Estrutura organizacional da VW em São Carlos 75 
6. APRESENTAÇÃO, ANÁLISE E DISCUSSÃO DOS DADOS 80

6.1 Análise dos dados 80

6.2 Grupo funcionários 81

6.2.1 Teste binomial $\quad 88$

6.2.2 Análise de correspondência 98

6.3 Grupo fornecedores 116

$\begin{array}{lll}\text { 6.3.1 Análise de correspondência } & 117\end{array}$

$\begin{array}{lll}6.4 & \text { Análise dos dados - entrevistas } & 119\end{array}$

7. CONSIDERAÇÕES FINAIS 128

$\begin{array}{lll}7.1 & \text { Trabalhos futuros } & 132\end{array}$

$\begin{array}{lll}7.2 & \text { Limitações do estudo } & 132\end{array}$

REFERÊNCIAS 134

APÊNDICE A 142

APÊNDICE B 143

$\begin{array}{ll}\text { APÊNDICE C } & 144\end{array}$ 


\section{CAPÍTULO 1 INTRODUÇÃO}

\subsection{APRESENTAÇÃO}

O papel de gerar toda a riqueza e poder da sociedade atual deixou de ser exclusividade dos fatores tradicionais de produção, capital, terra e trabalho. Tal afirmação, por si só, já serviria para justificar o fato de muitas empresas terem um valor de mercado extremamente superior ao seu valor patrimonial.

Isto ocorre devido ao fato do valor de produtos e serviços depender cada vez mais do percentual de inovação, tecnologia e conhecimento a eles incorporados, conhecimento este proveniente de seus funcionários sobre seus respectivos processos, e que por serem ativos intangíveis são de difícil gerenciamento.

Esta situação leva os gestores a travarem todos os dias uma batalha acirrada na busca da sobrevivência e continuidade de sua empresa, tornando-se fundamental, dentre outras coisas, a habilidade e capacidade de promover e assegurar a gestão dos ativos intangíveis da organização. Esta nova realidade passou a ser cada vez mais discutida e estudada por especialista, buscando respostas que auxiliem os gestores em sua rotina frenética e incessante de maximização de resultados.

$\mathrm{Na}$ vanguarda da indústria brasileira, as montadoras de veículos instaladas no país, constantemente buscam técnicas e mecanismos mais eficientes para seus respectivos sistemas produtivos. Sempre alerta a todos os movimentos que interagem em seu ambiente, tanto interno como externo, foi um dos primeiros setores a buscar soluções à crise iniciada com a abertura do mercado brasileiro no início dos anos 90.

Essas novas exigências impostas pelo mercado fizeram com que as montadoras, de um modo geral, priorizassem sua gestão do relacionamento e construção de alianças estratégicas, por ser inviável e caro a manutenção de todo o processo 
produtivo, ou seja, é mais vantajoso para as organizações compartilhar e dividir responsabilidades do que assumi-los sozinhos.

Destaca-se que esta mudança iniciou-se nos anos 90, onde, diversos setores no país experimentaram um processo de reestruturação produtiva. A indústria automobilística brasileira foi um dos segmentos mais atingidos, não apenas com as transformações tecnológicas, mas também com a introdução de novas alternativas de organização da produção e do trabalho.

Esses novos modelos organizacionais passaram a exigir das empresas elevada flexibilidade produtiva em um novo cenário de concorrência global, principalmente na condução de seus relacionamentos com fornecedores e funcionários, onde todos desempenham papéis importantes, ou seja, não são apenas meros coadjuvantes.

A esta nova realidade vivida pelas empresas deu-se o nome de gestão do capital de relacionamento, que retrata uma mudança de comportamento das organizações. Onde a manutenção de um relacionamento com os agentes que fazem parte de seus sistemas, juntamente com o estreitamento deste relacionamento tem se mostrado eficiente na condução de negócios, proporcionado mais confiança, comprometimento e segurança as partes envolvidas.

Destaca-se que não foram somente as novas configurações estruturais que motivaram as empresas a buscarem uma melhor gestão de seu capital de relacionamento, as relações com seus funcionários também passaram a ter um destaque especial, pois em mercados igualitários com disputas acirradas, o conhecimento compartilhado com os empregados tem se mostrado como grande diferencial.

Este novo cenário passa a ser decisivo e vital para que as empresas intensifiquem ações no sentido de alcançar sua produtividade e qualidade. Porém, as empresas necessitam caminhar na adoção de novas técnicas organizacionais buscando melhor gerenciamento do seu capital de relacionamento que é, de forma sucinta, a estrutura do conhecimento das organizações com as quais a empresa faz negócios com parceiros estratégicos, fornecedores e clientes.

\subsection{PROBLEMA DE PESQUISA}

Partindo desse cenário, o presente trabalho pretende evidenciar que para uma empresa criar vantagem competitiva e sobreviver em um mercado de economia 
globalizada é preciso considerar o capital de relacionamento como sendo um importante orientador estratégico. Assim, este trabalho baseia-se na análise e descrição da seguinte questão: Como uma empresa, conceituada e com ótimos índices de qualidade e produtividade, evidencia e gerencia seu capital de relacionamento?

\subsection{OBJETIVOS}

O objetivo principal desta pesquisa é analisar como uma empresa fabricante de motores conceituada e com ótimos indicadores de qualidade, situada na região central do Estado de São Paulo, gerencia seu capital de relacionamento, e ainda buscar respostas a alguns objetivos secundários, como:

- Analisar as características do relacionamento entre a empresa, seus fornecedores e funcionários;

- Analisar se o relacionamento com os fornecedores se converte em alianças estratégicas para a empresa;

- Analisar a qualidade deste relacionamento sob os aspectos de confiabilidade e comprometimento que a empresa mantém com seus fornecedores e colaboradores;

- Analisar a adaptação da empresa frente a esta nova realidade;

- Revisar e contribuir com a literatura sobre a gestão do capital de relacionamento.

Os objetivos propostos serão abordados e discutidos ms capítulos 2, 3 e 4, uma vez que servirão de guias e orientadores na condução e análise final do trabalho.

\subsubsection{JUSTIFICATIVA}

No Brasil novas formas de organização da produção, como o consórcio modular e, a mais comum, o condomínio industrial, foram aplicadas, principalmente, nas novas fábricas da Volkswagen em Resende - RJ, da GM em Gravataí - RS e a da Ford Camaçari, na Bahia. 
Condomínio industrial, conforme Salermo (1998), é definido como sendo a localização de unidades produtivas dentro das cercas da fábrica da montadora e que a diferença entre este sistema e o consórcio modular está no maior grau de valor agregado diretamente pela montadora no condomínio industrial.

Lima (2004) destaca alguns conceitos aplicados no setor automotivo que marcam a trajetória das montadoras em seu processo evolutivo a partir dos anos noventa e que se constituem numa espécie de reconfiguração estratégica. Dentre os conceitos principais destacam-se: desverticalização produtiva e práticas do modelo japonês; produção modular; sedes de projeto e plataforma mundial.

Essas formas revolucionárias e inovadoras no setor se apresentam como resposta à necessidade de redução de custos fixos da produção, dos custos logísticos totais e de maior flexibilidade nas atividades de produção de veículos, representando a inserção dos fornecedores de autopeças no processo de montagem, os quais passam a ser responsáveis por submontagens assumindo a função sistêmica.

Estas mudanças redefinem os focos das montadoras que começaram a priorizar seu negócio essencial ou core business, o advento da modulariedade ou produção modular e o volume de itens utilizados na produção de um veículo - cerca de 10 mil itens, são fatores que entre outros estimulam as montadoras a transferir cada vez mais a produção e a submontagem de módulos e conjuntos a fornecedores diretos que, em certos casos, compartilham o mesmo terreno da montadora, viabilizando a entrega de módulos e conjuntos submontados diretamente na linha de montagem final de veículo.

Esta nova situação tem instigado estes grupos a mudarem significativamente seu relacionamento, levando em muitos casos a criação de alianças e parcerias estratégicas. Uns dos motivos que justificam o estreitamento das relações entre montadoras e fornecedores é o fato de estimar-se que os componentes e peças sejam responsáveis por $60 \%$ a $75 \%$ do valor agregado e do custo final de um veículo (POSTHUMA, 1997).

Outros motivos que justificam o estudo proposto é a própria oportunidade do tema, sua importância para a competitivid ade das empresas, a busca em se preencher a lacuna que se apresenta na literatura acadêmica com relação a gestão do capital de relacionamento e sua importância para a empresa.

Destaca-se que este trabalho baseia-se na constatação de que o capital de relacionamento está assumindo novo papel, o de maior representatividade e importância estratégica nas montadoras. 


\subsubsection{MÉTODO DE PESQUISA}

Uma vez caracterizado o problema e determinado o objetivo do estudo, fica então definido qual a metodologia de trabalho, que parte do levantamento bibliográfico sobre o capital de relacionamento, a apresentação dos resultados obtidos no posterior estudo de caso, realizado na Volkswagen do Brasil - Fábrica de Motores de São Carlos, conforme observado através da Figura 1.

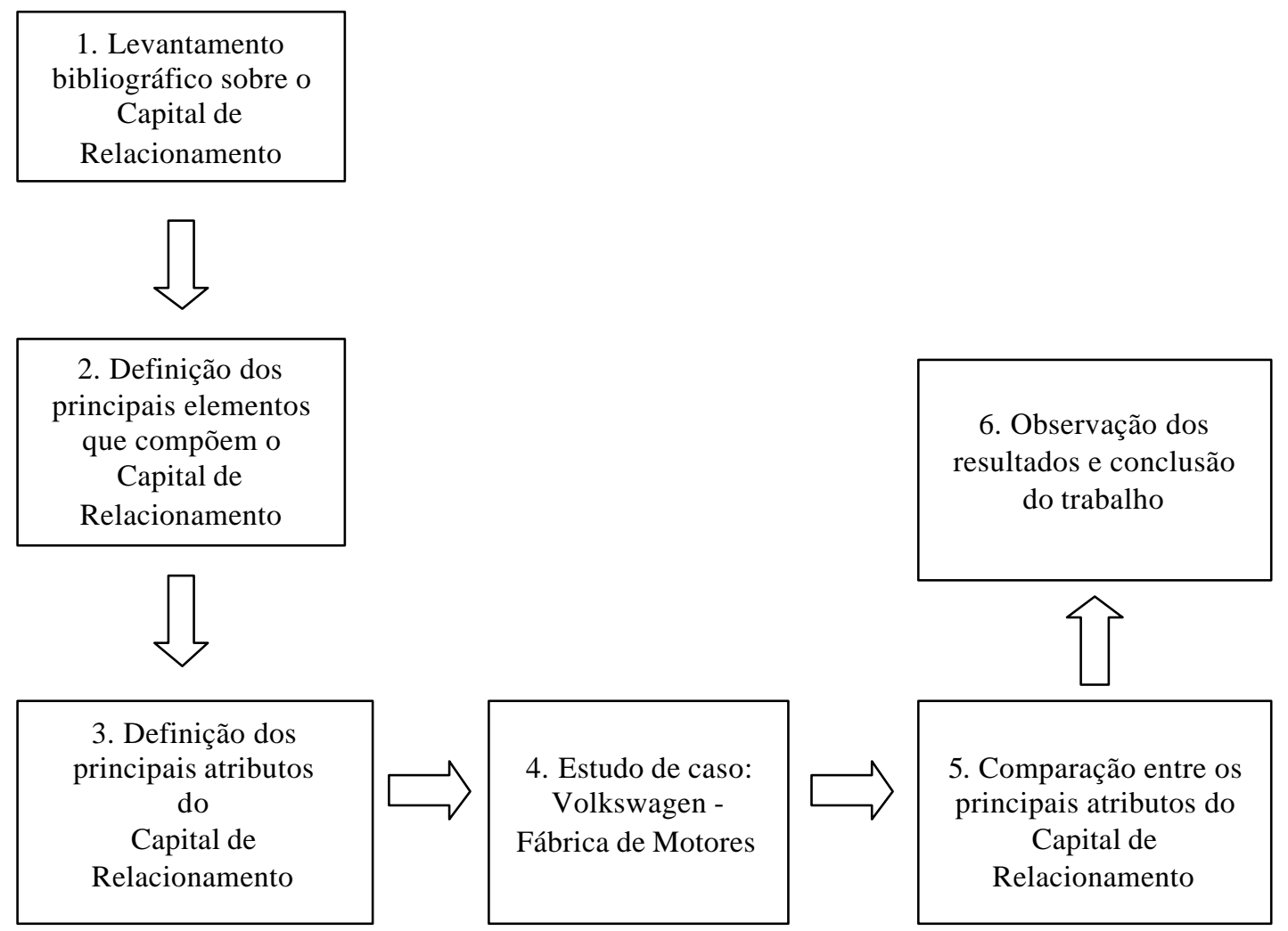

Figura 1: Esquema do método de trabalho

Para apresentar o capital de relacionamento, o primeiro passo é fazer o levantamento, através de uma pesquisa bibliográfica, dos elementos que compõem este capital, apresentando também os principais tipos de relacionamentos encontrados nas empresas.

O próximo passo é aplicar um questionário aos fornecedores, funcionários e alguns executivos da empresa objetivando confrontar as visões destes sobre os principais atributos identificados durante a realização do trabalho.

Posteriormente é feita uma comparação entre os resultados obtidos e uma análise do estudo de caso, procurando reconhecer as principais dificuldades encontradas 
na realização da pesquisa, juntamente com possíveis sugestões de melhorias. Por fim, é realizada as considerações finais do trabalho.

\subsection{ESTRUTURA DO TRABALHO}

Este trabalho está estruturado em 7 capítulos. Abaixo descrevem-se os capítulos, seus títulos e assuntos a serem abordados.

Capítulo 1 - Introdução. Descreveu a situação-problema, estabelecendo o problema central a ser enfocado, delimitando-o e estabelecendo seus principais objetivos. Identificou a importância e relevância deste trabalho. Apontou as justificativas para a realização do estudo proposto, bem como as contribuições por ele esperadas.

Capítulo 2 - Gestão do conhecimento. É a base inicial na condução deste trabalho, ou seja, o propulsor para a familiarização com o assunto, conhecimento ou intelecto, sendo este a matriz principal do próximo capítulo, o capital intelectual. Dentro deste realiza-se uma revisão bibliográfica sobre o tema, abordando inicialmente as diferentes interpretações, conceitos e definições, cujo objetivo é evidenciar a importância deste para alcançar vantagem competitiva em mercados globalizados. Em seguida comenta-se a evolução do conhecimento na humanidade, sua importância na nova economia e os tipos e características sob a ótica de diversos autores.

Capítulo 3 - Capital intelectual. Este capítulo apresenta uma revisão bibliográfica das definições, conceitos, estrutura, métodos de mensuração e elementos formadores que compõem o capital intelectual. Neste capítulo, destaca-se também definições sobre ativos intangíveis que compõem as empresas.

Capítulo 4 - Capital de Relacionamento. Neste capítulo realiza-se uma revisão bibliográfica sobre o tema principal em discussão, abordando suas definições, tipos de relacionamento e seus principais padrões. Destaca-se também a gestão do relacionamento com os clientes, também conhecida como CRM, e fornecedores.

Capítulo 5 - Método de pesquisa. Descreve o método de pesquisa utilizada no desenvolvimento deste trabalho, abordando o referencial teórico, o método no que tange seu objetivo, delineamento e instrumentos de coleta, baseado em um estudo exploratório da Fábrica de Motores São Carlos. 
Capítulo 6 - Apresentação, análises e discussão dos dados. Neste capítulo descreve-se a pesquisa realizada, os setores da empresa e os dados primários e secundários coletados.

Capítulo 7 - Considerações finais. Análises, contribuições para o tema, futuras pesquisas, limitações. 


\section{CAPÍtulO 2}

\section{GESTÃO DO CONHECIMENTO}

"O conhecimento deveria ser visto como algo inacabado, como um referente de possibilidades suscetíveis de serem construídas ou reconstruídas pelos grupos humanos".

(DAZA, 2003).

\subsection{INTRODUÇÃO}

Para as empresas aprenderem e renovarem constantemente seu conhecimento, a utilização de alguns conceitos tornou-se praticamente obrigatórios, como mudanças de estratégias e comportamentos, com destaque para o significativo estreitamento das relações com fornecedores, funcionários e clientes aproveitando o conhecimento e experiências destes.

Neste capitulo se discutirá a importância do conhecimento para as organizações, destacando-se suas definições, evolução, características e a importância de criar e gerenciar este ativo, tendo como respaldo o estudo de vários especialistas que têm se ocupado em estudar este gerenciamento na intenção de evidenciar seus principais benefícios.

Destaca-se que a gestão do conhecimento assume um papel importante na condução deste trabalho, pois da sua essência é que deriva o capital intelectual, que por sua vez serve como propulsor para o objeto principal deste estudo, o capital de relacionamento, ambos destacados e discutidos nos próximos capítulos.

Segundo Kruglianskas e Terra (2003), nos últimos anos o interesse pela gestão do conhecimento emergiu como um dos temas mais importantes na bibliografia sobre gestão empresarial. Hoje existem vários cursos de pós-graduação tratando do tema, e muitas empresas, inclusive no Brasil, começam a criar cargos do tipo "gerente de gestão 
de conhecimento", outras empresas como as de software já possuem vários aplicativos desenvolvidos especificamente para a gestão de conhecimento.

Por ser um conceito relativamente recente, pode-se afirmar que ainda está em construção. Diversos pontos de vista surgiram e foram apresentados em livros, artigos ou seminários por autores das mais variadas nacionalidades, tendências e formação acadêmica. O tema em si já foi tratado em áreas distintas como Administração, Engenharia de Produção, Psicologia, Ciência da Computação e Educação (PERROTTI, 2004).

Pimentel e Albino (2003) destacam que esta nova realidade transformou sensivelmente a maneira das organizações se relacionarem com o ambiente, onde a busca frenética por informações fez com que cada vez mais a empresa conheça o seu concorrente e seu dinamismo estratégico esteja cada vez mais presente. O diferencial de cada empresa pode estar contido em seu interior, ou seja, na sua força de trabalho e no conhecimento contido nas mentes de seus funcionários.

Este dinamismo acarretou profundas mudanças no perfil profissional exigido pelas empresas, onde os novos modelos de gestão demandam novas habilidades da força operária, incluindo participação, responsabilidade e cooperação dos trabalhadores, resultando em uma nova forma de organização do trabalho que vem sendo adotada pela indústria. Tais exigências propiciam um crescimento vertiginoso da demanda da sociedade por educação e formação profissional, uma vez que as empresas buscam profissionais de formação mais genérica e um conjunto de competências relacionadas às capacidades individuais, além das qualidades pessoais.

Perrotti (2004) destaca que a gestão do conhecimento é uma forma de tornar o ambiente favorável para que a organização identifique suas competências, encontre os conhecimentos que já possui, aprenda o que precisa, compartilhe e use estes conhecimentos na velocidade necessária ao desenvolvimento dos seus negócios.

Segundo Terra (2001) a compreensão do que venha a ser gestão do conhecimento implica na coordenação sistêmica de esforços em vários planos: organizacional e individual; estratégico e operacional; normas formais e informais.

\subsection{CONHECIMENTO - CONCEITOS E DEFINIÇÕES}


Áreas distintas têm suas próprias definições sobre o tema em questão. Destacando a importância de se definir o que seja ou represente o conhecimento, entende-se ser coerente apresentar os conceitos e definições filosóficas, econômicas e contemporâneas, facilitando assim sua interpretação, ressaltando que as definições a serem utilizadas dependerão do contexto em que o tema é empregado.

\subsubsection{DEFINIÇÕES FILOSÓFICAS, ECONÔMICAS E CONTEMPORÂNEAS}

O processo de busca para responder a pergunta "o que é conhecimento", representa a história da filosofia desde o período grego (NONAKA e TAKEUCHI, 1997).

Conforme Sveiby (1998), esta questão tem ocupado a mente dos filósofos ao longo do tempo sem que se tenha chegado a qualquer consenso, não havendo nenhuma definição da palavra aceita de modo geral. O termo epistemologia, teoria do conhecimento, provém da palavra grega episteme, que significa verdade absolutamente certa. Mas em português a palavra possui vários significados, como competência, habilidade, prática, etc.

Segundo Cotrim (1989), embora o problema do conhecimento tenha preocupado os filósofos desde a antiguidade, somente a partir da época moderna a teoria do conhecimento adquiriu grande importância, passando a ser tratada como uma das disciplinas centrais da filosofia.

O mesmo autor define a teoria do conhecimento como uma reflexão filosófica sobre o conhecimento, tendo como objetivo investigar suas origens, suas possibilidades, seus fundamentos, sua extensão e seu valor.

Outra aérea que também apresenta seus próprios conceitos e definições a respeito do que seja ou represente o conhecimento é a área econômica.

O conhecimento sempre foi a principal fonte de crescimento econômico em longo prazo, desde a revolução agrícola até os dias atuais. Sendo que na era atual a diferença está no impacto proporcionado pelo intensivo uso da tecnologia da informação (DAVENPORT e PRUSAK, 1999).

Os mesmos autores destacam que neste contexto, o fluxo de informações e o conhecimento gerado em sua decorrência são as principais características das atuais sociedades industrializadas. Contudo, o conhecimento gerado neste cenário, que tende a 
globalização, passou a ser alicerçado em novos padrões que alteraram as relações de produção e os processos de trabalho.

Drucker (1999) afirma que o conhecimento se tornou um recurso econômico fundamental e o mais dominante, sendo este, talvez, a única fonte de vantagem comparativa.

Sveiby (1998) destaca que a economia da era do conhecimento oferece recursos ilimitados porque a capacidade humana de gerar conhecimentos é infinita e, ao contrário dos recursos físicos, o conhecimento cresce quando é compartilhado.

Além das definições filosóficas e econômicas, os conceitos e definições contemporâneas também são importantes. Pimentel (2003) destaca que o conhecimento hoje ganhou importância em todos os aspectos do mundo moderno. E na era da globalização, embutido em produtos e serviços, pode fazer a diferença e destacar empresas no mercado.

Santos (2001) afirma que a era do conhecimento é igualmente a era de maior produtividade no trabalho, e quem não assimilar tal fato não poderá competir, o que equivale a dizer que não sobreviverá no início deste século XXI.

A economia vive um processo de reestruturação em escala global, onde a difusão das novas tecnologias e as novas práticas de organização e gestão das empresas estão transformando radicalmente as bases da concorrência nos mercados internacionais de produtos e serviços (MOURA, 1999).

\subsection{E EVOLUÇÃO DO CONHECIMENTO}

Segundo Cassará (2003) a história mostra que os grandes saltos do progresso da humanidade ocorreram, em primeiro lugar, pela ação do homem e, em segundo lugar, pela inovação. Não é difícil mencionar os avanços que ocorreram com a invenção da pólvora, pelos chineses, por volta do século XI, ou ainda, a invenção da bússola, no século XII, e mais recentemente com o advento do transistor, em 1947.

O mesmo autor considera, porém, surpreendente que somente no último quarto do século $\mathrm{XX}$, onde a ciência mais progrediu, permitindo ao homem a possibilidade de construir estações orbitais e de intervir diretamente no aprimoramento genético, é que está sendo dada maior ênfase a ciência das relações humanas, a conseqüente valorização 
do indivíduo e da gestão do conhecimento, pois percebeurse que o elemento humano é a vida e o componente principal do conhecimento em uma organização.

A história mostra a evolução do conhecimento humano como algo inacabado, ou seja, um produto em constante construção, visto por vários estudiosos como um dos fatores de maior peso no desenvolvimento econômico dos países, gerando riquezas para os que o detêm e muitas vezes submissão ou dependência para os que não o possuem. Da mesma forma que a evolução do conhecimento humano, o processo de criação do conhecimento humano também pode ser descrito como algo inacabado, ou seja, em constante transformação conforme mostra a Figura 2.

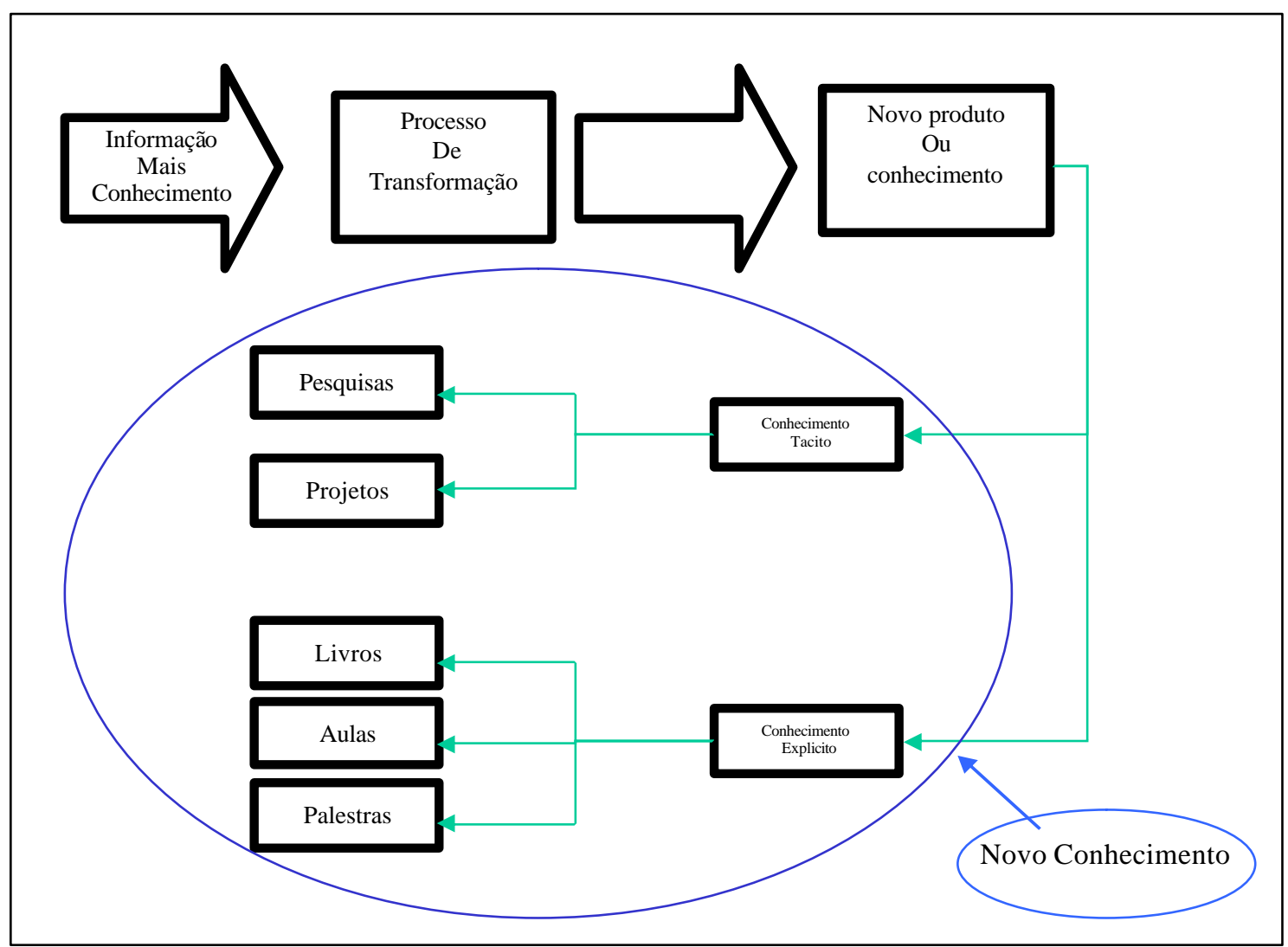

Figura 2 - Processo de criação do conhecimento humano. Fonte: Próprio autor.

O processo de transformação e criação do conhecimento humano molda-se com base em processos similares de transformação, constituídos em sua essência de entradas também conhecidas como Inputs, agentes de transformação e saídas conhecidas como Outputs.

Neste processo, os Inputs são constituídos da somatória de novas informações mais o conhecimento existente, onde posteriormente são transformados em novos 
conhecimentos através de sua interação com os agentes transformadores (homem e máquinas). O resultado deste processo é conhecido como Output, que dá início aos novos conhecimentos, que por sua vez podem ser separados em tácito e explicito, destacando que estes serão abordados nos próximos itens. É importante frisar que este proporciona a humanidade cada vez mais conhecimento.

Destaca-se também o aproveitamento pelas novas gerações dos conhecimentos já desenvolvidos por antigas gerações e culturas, evitando assim o desperdício de tempo e conhecimento em experimentos conhecidos, ou seja, utilizasse realmente todo o tempo disponível para experimentos novos ou pouco explorados.

Druker (1999) destaca que a sociedade atual é a do conhecimento, e que este é o recurso chave para os novos trabalhadores se tornarem o grupo dominante na força de trabalho desta sociedade que será a mais competitiva de todas, tanto para organizações, como para os indivíduos.

Para Toffler (1998), a era da chaminé foi superada, não havendo razões para falar de civilização industrial, mas de uma economia supersimbólica, que se baseia nos computadores, na troca de dados, de informação e conhecimento. Assim, o autor confere um mesmo estatuto teórico as três ondas: a primeira, entendida como revolução agrícola, a segunda como a revolução industrial e a atual como revolução da informática. A evolução do conhecimento é esquematicamente mostrada na Figura 3.

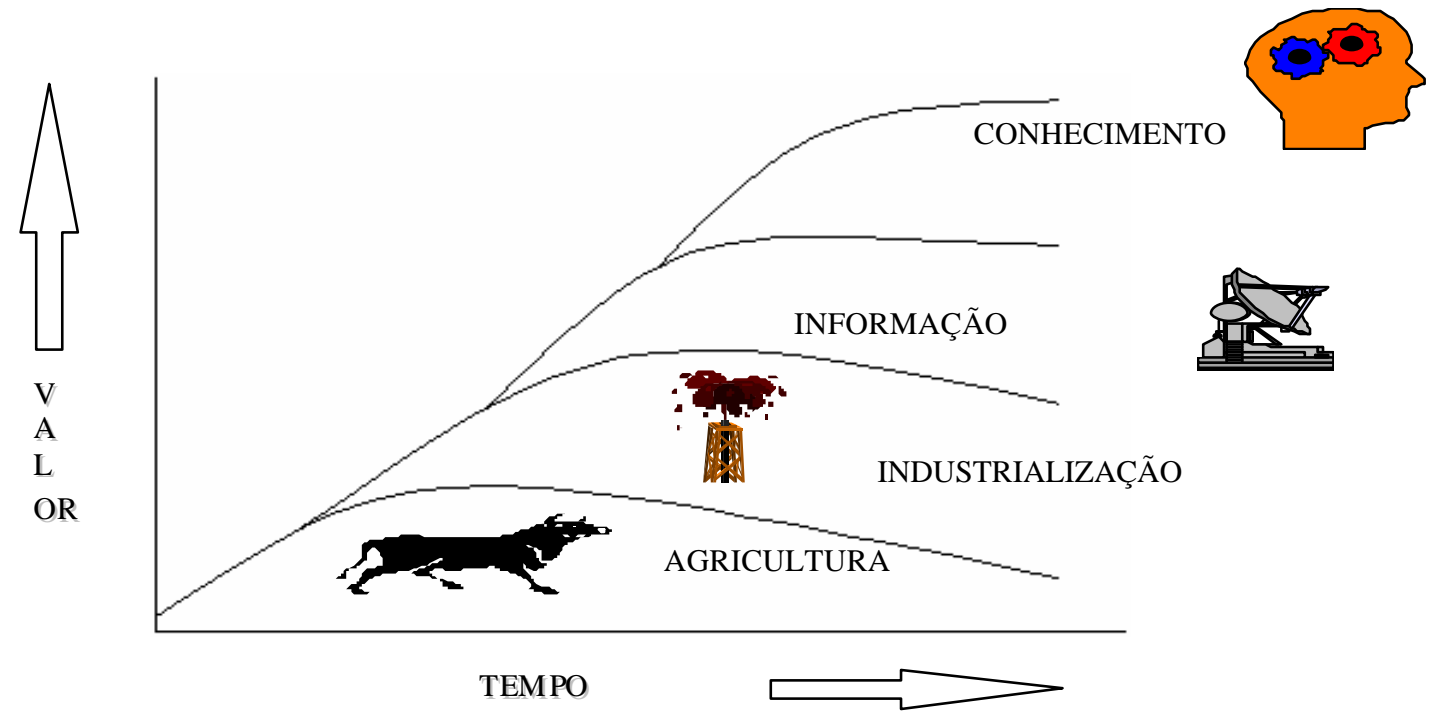

Figura 3 - Evolução do conhecimento.

Fonte: Próprio autor.

O conhecimento disponível hoje a humanidade passou por um longo período evolutivo, levando milhares de anos para sair da era da agricultura e chegar a era do 
conhecimento. Porém, o tempo de ultrapassagem de uma era para outra vem diminuindo significativamente, juntamente com o aumento do valor deste conhecimento para as pessoas e organizações.

\subsubsection{PRIMEIRA, SEGUNDA E TERCEIRA ONDA DO CONHECIMENTO}

Segundo Toffler (1998) a revolução agrícola, primeira onda, durou milhares de anos, iniciando-se por volta de 800 (a.C.) e estendendo-se até 1750 (d.C.), onde a partir deste momento começa a perder força, para a segunda onda que se aproximava da industrialização. Destaca-se neste período as inovações criadas pelo homem, como ferramentas, técnicas de cultivos utilizadas na agricultura.

Vital (1993) destaca que por volta de 900 (a.C.) os chineses já possuíam um bom conhecimento meteorológico, envolvendo o ciclo hidrológico, matemático, militar e astrológico, porém o autor destaca que mesmo com todo este conhecimento eles não chegaram a influenciar o ocidente.

Por milhares de anos as terras agrícolas vinham logo depois da organização social e do espírito empreendedor como bloco básico de construção na base da pirâmide de riqueza (THUROW, 2001). Porém, o autor destaca que depois da primeira revolução industrial, os recursos de energia substituíram as terras neste papel.

A segunda onda, caracterizada pela civilização industrial, dominou o planeta até 1955, onde o industrialismo foi, mais do que chaminés e linhas de montagens, um sistema rico e multiforme que locou os aspectos da vida humana (TOFFLER, 1998).

Seu período de influencia perdurou por aproximadamente trezentos anos, podendo-se comparar a revolução industrial a uma explosão que enviou ondas de concussão em cadeia através da terra, demolindo sociedades antigas e criando uma civilização inteiramente nova, criando a indústria de produção em massa, novos processos produtivos e novas máquinas.

A revolução industrial produziu a sociedade de massa com uma uniformidade social, política e cultural encorajada ou imposta. O industrialismo padronizou produtos, linguagens, rotinas, habitações e educação, e a definição destes critérios e regras conduziu as indústrias à eficácia, ou seja, as introduziu na era industrial (VITAL, 1993). 
Perrotti (2004) destaca que no processo de transição da era industrial para a era pós-industrial torna-se relevante que as organizações insiram como tema fundamental de sua visão cooperativa estratégica, a gestão do conhecimento.

Segundo Crawford (1998) a força propulsora para a transição de uma economia industrial para a era da informação é o aumento da produtividade causado por inovações em tecnologias, organização e administração.

Nos EUA, em 1995, ocorre o último ponto máximo histórico, a terceira onda ou era da informação. Pela primeira vez trabalhadores de colarinho branco e serviços gerais excederam em número os trabalhadores de macacão. Esta década marcourse pela introdução generalizada do computador, do jato comercial, da pílula anticoncepcional e muitas outras inovações de alto impacto na sociedade (TOFFLER, 1998).

Segundo McKenna (1999), a transformação tecnológica costuma ocorrer gradativamente. Os antibióticos levaram exatamente 30 anos para passar da pesquisa a realidade comercial. Hoje, as coisas estão muito diferentes, pois produtos desenvolvidos chegam aos mercados em menos de uma década.

$\mathrm{O}$ avanço na tecnologia e informação está fazendo com que produtos e companhias se modifiquem com uma rapidez nunca vista, estratégias empresariais que parecem promissoras num dia tornam-se obsoletas no outro (MCKENNA, 1999).

Nas ultimas décadas a sociedade contemporânea tem passado por inúmeras transformações, decorrentes do avanço da tecnologia e dos meios de comunicação que rompem fronteiras, aproximam pessoas, empresas, países e diferentes mercados. Esta nova era, a do conhecimento, traz mudanças profundas no estilo de vida e comportamento das pessoas, levando as empresas a repensarem seus valores, processos, estruturas e capacidades para atender à nova demanda (LAINO, 2004).

Conforme Druker (1999), esta nova era inicia-se após o colapso do marxismo e do comunismo no final dos anos oitenta, início dos anos noventa, encerrando duzentos e cinqüenta anos de domínio da crença da salvação da sociedade. Colocando como o novo recurso básico nas economias não mais o capital ou os recursos naturais, mas sim o conhecimento, sendo que a única vantagem possível nesta era é a capacidade para explorar o conhecimento universal disponível. Isto que será cada vez mais importante, tanto na economia nacional como na internacional, juntamente com o bom desempenho gerencial para tornar produtivo o conhecimento.

Para Fleury e Fleury (2001), numa economia baseada em conhecimento, o que mais adiciona valor são as atividades inteligentes onde o trabalho intelectual deve ser 
cada vez mais incentivado. Já as atividades rotineiras, manuais, passam a ser cada vez menos importante.

Drucker (1999) sugere também que um dos desafios mais importantes as organizações desta nova era é desenvolver sistemas para gerenciar a autotransformação. Estas têm de estar preparadas para abandonar o conhecimento que se torna obsoleto e aprender a criar um novo através de pontos como: melhoria contínua do todas as atividades; desenvolvimento de novas aplicações a partir de seus próprios sucessos e inovação contínua como um processo organizado.

\subsection{CLASSIFICAÇÃO DO CONHECIMENTO ORGANIZACIONAL}

As formas de conhecimentos existentes nas organizações dividem-se, basicamente, em dois grupos distintos, o conhecimento tácito e o conhecimento explícito, ambos amplamente utilizados por diversos autores.

\subsubsection{CONHECIMENTO TÁCITO}

O conhecimento tácito é identificado como conhecimento informal, ou seja, é um conhecimento pessoal enraizado na experiência individual e envolve crenças pessoais, perspectivas e valores (POLANYI, 1983).

Conforme Sveby (1998), o conhecimento humano é tácito, orientado para a ação, baseado em regras, individual e está em constante mutação. Em grande parte, este vem da prática principalmente das pessoas.

Segundo Polanyi (apud NONAKA e TAKEUCHI, 1997), o conhecimento tácito inclui elementos cognitivos e técnicos:

Elementos cognitivos: Centram-se nos elementos mentais onde os seres humanos criam modelos do mundo estabelecendo e manipulando analogia da mente.

Elementos técnicos: Incluem Know-How concreto, técnicas e habilidades.

Cavalcanti, Baldam e Valle (2002) analisam que o conhecimento tácito é subjetivo, está interiorizado dentro das pessoas, tornando-se difícil de ser explicado.

\subsubsection{CONHECIMENTO EXPLÍCITO}


Segundo Choo (apud PERROTI, 2004), conhecimento explícito é aquele que pode ser expresso formalmente com a utilização de um sistema de símbolos podendo ser facilmente codificado e difundido.

O conhecimento explícito envolve conhecimento dos fatores e é adquirido principalmente pela informação, quase sempre pela educação formal (SVEBY, 1998).

Cavalcanti, Baldam e Valle (2002), descrevem conhecimento explícito como sendo todo aquele que pode ser explicado oralmente ou por meios de documentos. E ainda que o conhecimento explícito pode estar documentado ou não:

Conhecimento explícito não documentado: É o conhecimento utilizado ao realizar-se uma atividade ou a construção de algo, onde as pessoas envolvidas no processo conhecem os procedimentos mesmo que estes não estejam devidamente documentados. Por exemplo, ao descrever-se perfeitamente a rota utilizada por uma pessoa de sua casa ao trabalho de forma que qualquer outro refaça o caminho, embora isto não esteja registrado em nenhum documento, resume a essência do conhecimento explícito não documentado.

Conhecimento explícito documentado: É imprescindível quando deseja-se fazer a gestão do conhecimento na organização. Onde o objetivo principal das empresas é explicar ao máximo o conhecimento, tornando mais fácil o aprendizado e a transmissão do mesmo, utiliza-se amplamente este procedimento nas organizações por meio de cartas de versatilidades e folhas de processos.

\subsubsection{A INTERAÇÃO DOS CONHECIMENTOS TÁCITOS E EXPLÍCITOS}

Segundo Sveiby (1998) uma empresa criadora de conhecimento é aquela capaz de mudar suas regras fundamentais pela interação entre os conhecimentos tácitos e explícitos.

Nonaka e Takeuchi (1997) chamam esta interação de conhecimentos em conversão de processos de conhecimento, que se dá por meio de quatro categorias: a socialização, exteriorização, interiorização e combinação (Figura 4). 
PARA

\begin{tabular}{l|c|c|}
\multicolumn{1}{l}{ Conhecimento tácito } & \multicolumn{1}{c}{ Conhecimento tácito } & \multicolumn{1}{c}{ Conhecimento explícito } \\
\cline { 2 - 3 } DE & Socialização & Exteriorização \\
\cline { 2 - 3 } Conhecimento explícito & Interiorização & Combinação \\
\cline { 2 - 3 } & & \\
&
\end{tabular}

Figura 4 - Quatro modos de conversão de conhecimento. Fonte: Nonaka e Takeuchi (1997), p. 69.

Socialização: É um processo de experiências, portanto, de criação de conhecimentos tácitos, como modelos e habilidades mentais compartilhados. Por exemplo, quando trabalham com seus mestres, os aprendizes aprendem a perícia profissional por meio da observação, da imitação e da prática, somente a linguagem não é suficiente.

Exteriorização: É um processo de articulação do conhecimento tácito em conceitos explícitos. Na linguagem falada, o conhecimento tácito assume a forma de metáforas, modelos, conceitos e equações que expressam, de forma reduzida e um tanto distorcida, o conhecimento tácito de um indivíduo.

Combinação: É um processo de sistematização de conceitos explícitos em sistema de conhecimento, ou seja, é a combinação de diferentes partes de conhecimento explícito em um novo conhecimento explícito por meio da análise, da categorização e da reconfiguração de informações. Esta forma de conversão de conhecimento ocorre nas universidades e em outras instituições de educação formal.

Interiorização: É a absorção do conhecimento explícito em conhecimento tácito e, está intimamente relacionada ao aprendizado pela prática. Esta é favorecida se o conhecimento for verbalizado em forma de histórias contadas oralmente ou se forem utilizados processos de documentação de sistemas. Simulações é outra forma de realizar este modo de conversão de conhecimento com o intuito de melhorar a criação.

Os quatro modos de conversão de conhecimento podem ser utilizados para beneficiar o processo de produção dos profissionais que trabalham nas organizações do conhecimento. 


\subsection{A CRIAÇÃO DO CONHECIMENTO ORGANIZACIONAL}

Rodrigues, Antunes e Dutra (2003) definem a criação do conhecimento organizacional como a capacidade que uma empresa tem de criar conhecimento, disseminá-los na organização e incorporá-los a produtos, serviços e sistemas. E ainda que o indivíduo interaja com a organização por meio do conhecimento e criação do mesmo. Os autores também destacam que as formas de interação do conhecimento e os níveis de criação apresentam-se como componentes principais de sua criação.

Segundo Nonaka e Takeuchi (1997), a função da empresa no processo de criação do conhecimento organizacional é fornecer o contexto apropriado para a facilitação das atividades em grupo e para criação e acúmulo de conhecimento em nível individual. Para o processo de criação desse conhecimento organizacional, destacam o modelo de integração de cinco fases: o compartilhamento do conhecimento tácito; criação de conceitos; justificativa dos conceitos; construção de um arquétipo e difusão interativa do conhecimento (cross-leveling knowlede):

Primeira fase: o compartilhamento do conhecimento tácito. Esta fase corresponde aproximadamente a socialização, pois, inicialmente, o conhecimento rico e inexplorado que habita os indivíduos precisa ser amplificado dentro da organização, criando mecanismos de interação entre eles através de diálogos pessoais.

Segunda fase: criação de conceitos. $\mathrm{Na}$ segunda fase, o conhecimento tácito compartilhado, por exemplo, por uma equipe auto organizada é convertido em conhecimento explícito na forma de um novo conceito, um processo semelhante a externalização.

Terceira fase: justificativa dos conceitos. $O$ conceito criado precisa ser justificado, e é nesta fase que a organização determina se vale realmente a pena perseguir o novo conceito.

Quarta fase: construção de um arquétipo. Recebido o sinal verde nesta fase, os conceitos são convertidos em um arquétipo, que pode assumir a forma de um protótipo no caso do desenvolvimento de um produto concreto ou em um mecanismo operacional no caso de inovações abstratas, por exemplo, um novo valor da empresa, um sistema gerencial inovador ou uma estrutura organizacional.

Quinta fase: difusão interativa do conhecimento (cross-leveling knowlede). Amplia-se o conhecimento criado, por exemplo, em uma divisão a outras pessoas da 
mesma divisão, a outras divisões ou até a componentes externos constituindo o que chamamos de difusão interativa do conhecimento. Esses componentes externos incluem clientes, empresas afiliadas, universidades e distribuidores.

E importante destacar que uma empresa criadora de conhecimento não opera em um sistema fechado, mas em um sistema aberto, no qual existe um intercâmbio constante de conhecimento com o ambiente externo.

\subsection{APRENDIZAGEM ORGANIZACIONAL}

Conforme Bitencourt (2004), aprendizagem organizacional pode ser considerada uma resposta as mudanças enfrentadas pelas empresas, em que se busca desenvolver a capacidade de aprender continuamente a partir das experiências organizacionais e a traduzir esses conhecimentos em práticas que contribuam para melhor desempenho tornando a empresa mais competitiva. Portanto, seus pressupostos são o desenvolvimento de estratégias e procedimentos a serem continuamente construídos para se atingirem melhores resultados, contando com a participação efetiva das pessoas no processo de aquisição e disseminação de conhecimento.

Segundo Fleury e Fleury (2004), o processo de aprendizagem em uma organização não só envolve a elaboração de novos mapas cognitivos que possibilitem compreender melhor o que está ocorrendo em seu ambiente externo e interno, como também a definição de novos comportamentos que comprovam a efetividade do aprendizado. Desta forma, os autores destacam alguns conceitos de aprendizagem organizacional elaborados por pesquisadores em diferentes épocas, atentando para as múltiplas facetas do processo:

- Aprendizagem organizacional é um processo de identificação e correção de erros (Argytis, apud FLEURY e FLEURY, 2004, p.116);

- Aprendizagem organizacional significa um processo de aperfeiçoar as ações pelo melhor conhecimento e compreensão (FIOL e LYLES, 1985, p. $803)$;

- Organizações que aprendem são organizações capacitadas em criar, adquirir e transferir conhecimento e modificar seus comportamentos para refletir esses novos conhecimentos e insight (GARVIN, 1993, p.80); 
- Uma organização está continuamente expandindo sua capacidade de criar o futuro (SENGE, 1990, p.14).

As definições mais comuns das organizações que aprendem, enfatizam sua capacidade de adaptação a taxas aceleradas de mudanças que ocorrem atualmente no mundo e, segundo Senge (1990) as organizações devem desenvolver cinco disciplinas fundamentais para o processo de inovação e aprendizagem:

Domínio pessoal: através do auto-conhecimento, as pessoas aprendem a clarificar e aprofundar seus próprios objetivos, a concentrar esforços e a ver a realidade de forma objetiva.

Modelos mentais: são idéias profundamente enraizadas, generalizadas e mesmo imagens que influenciam o modo como as pessoas vêem o mundo e suas atitudes.

Visões partilhadas: quando um objetivo é percebido como concreto e legítimo, as pessoas dedicam-se e aprendem não como obrigação, mas por vontade própria, construindo visões compartilhadas.

Aprendizagem em grupo: em grupos cujas habilidades coletivas são maiores que as habilidades individuais, desenvolve-se a capacidade para ação coordenada.

Pensamento sistêmico: constitui um modelo conceitual, composto de conhecimento e instrumentos desenvolvidos ao longo dos últimos 50 anos, que visam melhorar o processo de aprendizagem como um todo e apontar futuras direções parar o aperfeiçoamento.

Estas disciplinas buscam construir guias de ações que visam o desenvolvimento da aprendizagem organizacional, através do conhecimento e explicitação dos modelos mentais individuais, de grupo e construção de projetos coletivos.

Garvin (apud FLEURY e FLEURY, 1995) considera que existem cinco caminhos nos quais o aprendizado pode ocorrer: resolução sistêmica dos problemas, experimentação, experiências passadas, circulação de conhecimento e experiências realizadas por outros.

Terra (2003) destaca algumas características nas organizações de aprendizagem, citadas por diversos autores:

- Reconhecimento explícito do valor econômico do conhecimento; 
- Capacidade de desenvolver o Know-why, além do know-how;

- Capacidade de questionar valores, cultura e mudar o comportamento;

- Estímulo a experiência e aprendizado através da detecção e correção de erros;

- Habilidade em compartilhar insight, experiências e informações individuais;

- Habilidade criadora;

- Capacidade em articular conhecimento conceituais sobre uma experiência;

- Utilização da capacidade criativa de seus funcionários;

- Busca ativa de informações do ambiente onde se inserem;

- Sistemas de informação precisos e com formato que facilita o uso.

Segundo Alvessom e Willmott (apud RODRIGUES, CHILD e LUZ, 2004), aprendizagem pode ser uma arma poderosa da mudança desde que possa ser usada para estimular o desenvolvimento da orientação para o trabalho e identidades do trabalho que são congruentes com os objetivos dos administradores.

\subsection{A ORGANIZAÇÃO QUE APRENDE}

Rodrigues, Antunes e Dutra (2003) afirmam que a idéia de organização que aprende foi lançada por Senge em 1990 e tornou-se uma das paixões da administração. A proposta de diversos especialistas é que as organizações precisam aprender que o conhecimento organizacional é mais do que a soma do conhecimento dos indivíduos da empresa. O ponto central é a eficácia de como os indivíduos transferem o que sabem para a organização como um todo.

Segundo Santos (2003), as organizações que aprendem são aque las nas quais as pessoas estimulam continuamente sua capacidade para criar o futuro que realmente gostariam de ver surgir, e ainda que este é um conceito que envolve o coração e a mente dos funcionários em uma mudança contínua, harmoniosa e produtiva, projetada para alcançar os resultados almejados.

Santos (2001) destaca também alguns atributos em forma de questões para distinguir uma organização que aprende de outras, onde se a somatória de resposta indicar a variável sempre, melhor será o resultado para a empresa. Outras variáveis 
também utilizadas são: freqüentemente, às vezes, quase nunca, e nunca. Listam-se a seguir os itens do teste:

- A organização aprende com a experiência e não repete os erros;

- Quando alguém deixa a organização, seu conhecimento permanece;

- Concluída a tarefa, a equipe divulga a documentação ou o que foi aprendido;

- O conhecimento gerado em todas as áreas da empresa é pesquisado, legitimado e posto a disposição de toda a organização por meio de banco de dados, treinamento e outros meios de aprendizagem;

- A organização reconhece e recompensa o valor do conhecimento gerado e compartilhado por pessoas e equipes;

- A organização avalia de modo sistêmico suas necessidades futuras de conhecimento e desenvolve planos para atendê-las;

- A organização facilita a experiência como um meio de aprender;

- A organização estimula sua capacidade de gerar, adquirir e aplicar o conhecimento, aprendendo com os processos de aprendizagem de outras organizações.

Bartlett e Ghoshal (apud SANTOS, 2003) identificam três atributos essenciais da capacidade para assimilar o conceito de organização que aprende: muito tempo e esforço dedicados a atrair, desenvolver e manter seus melhores funcionários. "Gestão do conhecimento"; investimento em recursos substanciais na criação de ferramentas e processos necessários para dar apoio a fluxos horizontais de conhecimento, permitindo elevar o conhecimento individual e inserílo em um processo coletivo de intercâmbio de aprendizagem; desenvolvimento de forte sentimento de confiança, que passou a ser base de desenvolvimento da capacidade individual e de aprendizagem organizacional.

Segundo Bitencourt (2002), na organização que aprende, o papel dos lideres é radicalmente diferente do carismático tomador de decisão. Os lideres são projetistas, professores e capitães, esses papéis exigem novas habilidades: a capacidade de conhecer uma visão comum; trazer a tona e questionar os modelos mentais predominantes; estimular o raciocínio sistêmico. Em resumo, os lideres na organização que aprendem tem a responsabilidade de formar organizações nas quais as pessoas ampliem 
constantemente sua capacidade de moldar o futuro, ou seja, os lideres são responsáveis pelo aprendizado.

O mesmo autor destaca que um líder inserido num contexto de aprendizagem deve criar uma visão, dar exemplo, cultivar um ambiente de apoio, não ser tirano e ouvir o que não tem vontade de ouvir.

White e Grainer (apud BITENCOURT, 2002) complementam destacando as cinco habilidades da liderança em um ambiente de mudanças: aprendizado difícil, aprender com dificuldade (criatividade); energia (dinamismo organizacional); foco (obsessão); simplicidade (melhoria contínua) e percepção (autoconsciência - dominar a intuição).

É importante salientar que estas habilidades devem ser desenvolvidas por todas as pessoas da organização e não por uma elite. Em organizações que buscam o aprendizado coletivo, as diferenças individuais devem ser valorizadas pela equipe como uma forma de ampliar o foco de análise, permitindo aprimorar a percepção.

\subsection{MEMÓRIA ORGANIZACIONAL}

O interesse que as organizações demonstram por seu crescimento levoutas a buscar a administração de seu conhecimento e experiência por meio de novas formas de acesso e manutenção de sua parte intelectual. Uma possibilidade para que isto ocorra é promover sua memória organizacional, ou seja, realizar registros do conhecimento da organização (SOLTERO, 2003).

O mesmo autor define memória organizacional como sendo o conhecimento organizado com persistência, algo que pode ser constituído por dados e armazenado. A memória organizacional não é apenas um facilitador para o acúmulo e para a preservação, mas também para o compartilhamento do conhecimento, e como este é explícito e administrado leva ao aumento do intelecto organizacional, chegando a ser a base para a comunicação e para o entendimento.

O conhecimento é a principal vantagem de uma organização e a memória organizacional estende e amplia essa vantagem por meio da captura, organização, disseminação e reutilização do conhecimento criado por seus empregados. A construção da memória organizacional refere-se ao processo de armazenagem de informações com base na história organizacional, as quais podem ser recuperadas e 
auxiliar na tomada de decisões presentes. As informações são estocadas e as experiências passadas, tanto as bem-sucedidas como as mal-sucedidas devem ser de fácil recuperação e estar a disposição das pessoas (FLEURY e FLEURY, 2001).

\subsection{CULTURA ORGANIZACIONAL}

A abrangência da cultura organizacional é mais ampla do que se pode supor. Ela exprime a identidade da organização, resultante de um sistema de significações que atua como elo de todos os membros em torno de objetivos comuns.

Segundo Perrotti (2004) as organizações são as expressões de uma realidade cultural, e essa realidade cultural reflete os valores, as crenças, as idéias, os sentimentos e as vontades da comunidade institucional.

Fleury e Fleury (1995) afirmam que cultura organizacional é um conjunto de valores expressos em elementos simbólicos e em práticas organizacionais que, em sua capacidade de ordenar, atribui significações, constrói a identidade organizacional, tanto agem como elementos de comunicação e consenso, como expressam e instrumentalizam relações de dominação.

Para Shein (1986) a cultura é formada pelo conjunto de pressupostos básicos que um grupo inventou, descobriu ou desenvolveu ao aprender a lidar com os problemas de adaptação externa e integração interna e que funcionaram bem o suficiente para serem considerados válidos e ensinados a novos membros como a forma de perceber, pensar e sentir com relação a esses problemas.

Conforme Robbins (2002) a cultura cumpre várias funções no seio de uma organização: cumpre a função de definir os limites, ou seja, os comportamentos que diferenciam uns de outros; transmite um sentido de identidade a seus membros; facilita a criação de um comprometimento pessoal com algo mais amplo que os interesses egoístas do indivíduo e estimula a estabilidade do sistema social.

A cultura é o vínculo social que ajuda a manter a organização unida ao proporcionar normas adequadas do que devem fazer os empregados.

O processo de se construir uma cultura de aprendizagem é o grande desafio enfrentado pelas empresas, este desenvolvimento implica em valores básicos fundamentados na prática organizacional, apoiados principalmente nas pessoas como base deste processo (FLEURY e FLEURY, 1995). 
Robbins (2000) destaca que as dimensões da cultura organizacional ajudam a explicar as forças sutis que influenciam as ações dos empregados, reconhecendo que grandes unidades dentro de uma organização podem ter uma diferente cultura. Por esses motivos o autor aborda a importância de se estudar estas dimensões que influenciam a cultura das empresas:

Valores. Os valores são os fundamentos de qualquer cultura organizacional. A filosofia da organização é expressa através de valores, e estes dirigem o comportamento através do dia a dia.

Diversidade relativa. A existência de uma cultura organizacional presume algum nível de homogeneidade. No entanto, as organizações diferem em termos de quantos desvios podem ser tolerados.

Alocação de recursos e premiação. A alocação de dinheiro e outros recursos tem uma influencia crítica sobre a cultura. O investimento de recursos envia uma mensagem as pessoas sobre o que é valorizado na organização.

Nível de mudança. Uma organização dinâmica, que evolui rapidamente, tem uma cultura diferente daquela que é parada e estável. Os administradores de alto nível, pela energia ou letargia de seu passo, enviam mensagens sobre como a inovação é bem vinda ou não.

Força da cultura. A força de uma cultura, ou quanta influência ela exerce, é parcialmente um subproduto das outras dimensões. Uma cultura forte dirige os empregados em muitas ações cotidianas.

Para Robbins (2000) a cultura organizacional recebe muita atenção porque tem um impacto penetrante na eficácia organizacional e, uma das maneiras de se conhecer ou inferir sobre a cultura de uma organização é estudando sua estrutura, seus sistemas de informação e controle, sua missão, objetivos e história.

Segundo Terra (2001) uma das preocupações da alta administração deve ser o desenvolvimento de uma cultura organizacional voltada a inovação, a experimentação, ao aprendizado contínuo e o compromisso com resultados de longo prazo.

\subsection{MAPEAMENTO DE COMPETÊNCIAS E CONHECIMENTO}

Segundo Santiago Junior (2002), para tornar possível o processo de utilização do conhecimento da empresa, obviamente se faz necessário a localização das fontes 
deste conhecimento, o que é feito através do mapeamento das competências. Somente através deste é possível identificar os especialistas, pessoas com profundo conhecimento de um dado assunto, e localizar o acervo prescrito na empresa.

O mesmo autor considera que mais importante que importar experiências bem sucedidas externamente é localizar as ilhas de eficiência internas e promover a disseminação das boas práticas (estimular o benchmark interno). O mapeamento destas competências facilita a localização dos detentores de conhecimento, agilizando sua disseminação e a formação de times de trabalhos para novos projetos.

Conforme Hamel e Prahalad (1995), não é possível prestar atenção a tudo, deve haver alguma noção das atividades que realmente contribuem para a prosperidade da organização a longo prazo. O objetivo é concentrar atenção nas competências localizadas no centro do sucesso competitivo a longo prazo e não na periferia.

Segundo Davenport e Prusak (1998) um mapa de conhecimento, seja ele um mapa real, páginas amarelas do conhecimento ou um banco de dados sofisticado, indica o conhecimento, porém não o contêm, tratando-se de um guia e não um repositório. $O$ desenvolvimento de um mapa do conhecimento envolve localizar conhecimentos importantes dentro da empresa e depois publicar em algum tipo de lista ou quadro que mostre onde encontrá-los. Mapas de conhecimento apontam tipicamente para pessoas e também para documentos e banco de dados.

A principal finalidade e o mais evidente beneficio de um mapa do conhecimento é mostrar para as pessoas de dentro da empresa para onde ir quando necessitarem de conhecimento (PERROTTI, 2004).

No entanto, não se pode esquecer que conhecimento e talento não são sinônimos de formação acadêmica. Sendo assim, há grandes inconvenientes ao se ignorar o conhecimento vindo dos cargos hierárquicos mais baixos. O conhecimento pode estar em qualquer lugar na empresa, o que exige a sua procura em todos os lugares, independentemente da área e da capacitação explícita dos funcionários (SANTIAGO JUNIOR, 2002).

O mesmo autor destaca ainda que além deste mapeamento, é necessária uma gestão participativa das informações e dos conhecimentos que permita uma visualização e atualização imediata das competências da empresa, isto é, um balanço permanente do Know-how da empresa e incentivo no processo de auto-informação. É importante considerar a existência de uma área ou departamento que tenha uma atenção especial nesta gestão de competências e conhecimento, alinhado aos intentos estratégicos 
definidos pela organização como um todo. Esta área deve conter estreito contato com as áreas de gerenciamento de recursos humanos e de tecnologia da informação.

\subsection{GESTÃO DO CONHECIMENTO: A NOVA REALIDADE}

A definição de gestão do conhecimento ainda gera controvérsias entre os autores. Alguns, na intenção de dar a devida importância ao tema, colocam a gestão do conhecimento quase como um sinônimo da própria ciência da administração (PERROTI, 2004).

Segundo Rodrigues, Antunes e Dutra (2003) a gestão do conhecimento está emergindo como uma prática gerencial devido a investimentos maciços em tecnologia da informação, ampliação do contato com clientes, funcionários mais empreendedores, movimentos de downizing e reestruturação e demanda dos clientes.

Os mesmos autores concordam que uma integração das abordagens atualmente empregadas como gestão da qualidade total, do conhecimento, inteligência competitiva e capital intelectual, tendo como foco a inovação, poderão gerar, no futuro, alternativas a serem aplicadas na gestão de negócios e resultados das empresas.

A gestão do conhecimento é uma forma necessária de abordar a administração de empresas na era do conhecimento. Como citado por diversos autores neste capítulo, não é algo novo, mas intensificou-se a preocupação pelo ser humano e pelo que este sabe, já que a nova sociedade valoriza o conhecimento. Trata-se de uma realidade, pois diversos estudos mostram que, neste contexto, as empresas administradas sob uma ótica mais focada em aprendizagem e inovação tendem a ter mais sucesso que as demais.

O conhecimento e sua gestão não podem ser considerados como algo novo, pois as empresas sempre valorizaram o Know-how, a experiência e a capacidade de resolução de problemas de seus empregados. O que se observa como novo é a ênfase sobre este recurso, a descoberta de que as ações aleatórias antes adotadas não são mais suficientes para enfrentar o nível de concorrência atual (ORSI, 2003).

Terra (1999) destaca que as práticas gerenciais que foram relacionadas a uma efetiva gestão do conhecimento e, conseqüentemente, ao estímulo do aprendizado, a criatividade e a inovação no contexto organizacional, estão fortemente associadas a melhores desempenhos empresariais. 


\section{CAPÍtULLO 3}

\section{CAPITAL INTELECTUAL}

"A inteligência humana e os recursos intelectuais constituem presentemente os ativos mais valiosos de qualquer empresa”.

(SVEIBY, 1998).

\subsection{INTRODUÇÃO}

No capitulo anterior se observou a importância da gestão do conhecimento para as empresas, porém o conhecimento é algo mais amplo que abrange várias ramificações de estudos. Dentro deste contexto, o capital intelectual é uma ramificação amplamente discutida e atualmente vários pesquisadores se ocupam em estudá-lo com o objetivo de melhor aproveitar seus resultados.

Pela importância alcançada por este ativo intangível, neste capítulo pretendese apresentar a melhor, ou um conjunto, de suas melhores definições, evidenciar sua estrutura, os elementos que o compõe, juntamente com as melhores formas de se gerenciá-lo e evidenciá-lo às organizações.

Segundo Edvinsson e Malone (1998), os gestores hoje lutam fortemente para ajustar-se ao deslocamento do centro de gravidade da administração e da medição de ativos físicos e financeiros para o cultivo e a utilização do conhecimento como atos mais significativos na criação de valor.

Andrade e Tomaz (2003) consideram este conhecimento como o maior impulsionador de todo ativo intangível de uma empresa e, assim como na economia digital, os ativos intangíveis ganharam maior valor que os tangíveis. Gerir este conhecimento, assim como já se geriu os ativos tangíveis (capital, bens, equipamentos etc.), torna-se primordial para o alcance de uma posição sustentável no mercado. 
Os mesmos autores destacam que gestão do conhecimento é todo o esforço sistemático realizado pela organização para identificar, capturar, compartilhar, obter, criar, organizar, melhorar, reter e medir seu conhecimento. É uma estratégia que transforma ativos intangíveis (informação armazenada de seus membros em produtividade, valor e aumento de competitividade) e ensina corporações, de gerentes a empregados, a como produzir e otimizar habilidades como uma entidade coletiva.

Segundo Matheus (2003), na gestão voltada para criação de valor é necessário utilizar metodologias mais adequadas para sua mensuração, que pode ser feito de forma indireta através da mensuração do desempenho econômico-financeiro da organização que, por sua vez, pode ser realizada através da determinação do valor da empresa. Ressaltando-se também a necessidade dos gestores focarem cada vez mais suas atenções em elementos, estratégias, decisões e atitudes que venham criar valor à organização.

O mesmo autor destaca que, além da estrutura física e das máquinas pertencentes a empresa (ativos tangíveis), o que cria valor para as organizações são as decisões mais acertadas e coerentes relacionadas aos fatores ou elementos correspondentes aos ativos intangíveis da empresa como: a eficácia de seus sistemas gerenciais; a capacidade e a competência de seus funcionários; o bom relacionamento com clientes, fornecedores e também com os próprios funcionários; as soluções inovadoras; a informação mais precisa, confiável e mais rápida; a credibilidade e a confiança nos produtos e serviços oferecidos; o conhecimento sistematizado e disponível aos funcionários, dentre outros fatores.

Para Stewart (1998), Edvinsson e Malone (1998) os ativos intangíveis das empresas são seu capital intelectual e, creditam a este capital a responsabilidade pela geração da parcela de valor que não advém dos ativos tangíveis das empresas.

\subsection{ATIVOS INTANGÍVEIS}

Os ativos constituem toda a propriedade de uma empresa que pode ser expressa por um valor em dinheiro, e estes ativos se apresentam sobre quatro formas, as duas primeiras categorias são os ativos circulantes e permanentes, a terceira categoria os investimentos e por último, a quarta forma, representa os ativos intangíveis que não possuem existência física, mas, mesmo assim representam valor para a empresa (EDVINSSON e MALONE, 1998). 
Os mesmos autores destacam que os ativos intangíveis constituem os extremos da contabilidade, por um lado a categoria abrange todos os ativos corporativos que mesmo sendo transitórios, simplesmente não se enquadram nas três formas anteriores admiravelmente rígidas. Por outro lado, a existência de ativos intangíveis representa a admissão tácita pelo mundo da contabilidade que sua equivalência possui na realidade um fator interno limitante que se torna menos empírico e mais irracional a medida que se examina com maior atenção. Seu surgimento se deu em resposta a um crescente reconhecimento de que fatores extra contábeis podem ter uma importante participação no valor real de uma empresa.

Para Sveiby (1998), a diferença entre o valor de mercado de uma empresa de capital aberto e seu valor contábil líquido oficial é o valor dos ativos intangíveis, onde, na maioria das empresas, o valor dos ativos intangíveis é superior ao dos ativos tangíveis. A parte invisível do balanço patrimonial consiste em três grupos de ativos intangíveis:

Competência do funcionário: A competência do funcionário envolve a capacidade de agir em diversas situações para criar tanto ativos tangíveis como intangíveis. Porém, há quem não concorde que a competência do funcionário seja um ativo intangível, pois a competência individual não pode ser propriedade de ninguém ou de qualquer coisa a não ser da pessoa que a possui, no final das contas, os funcionários são membros voluntários de uma organização.

Todavia esta competência deve ser incluída no balanço patrimonial dos ativos intangíveis porque é impossível conceber uma organização sem pessoas. Além disso, as pessoas tendem a ser fiéis se forem tratadas de forma justa e tiverem a sensação de responsabilidade compartilhada.

Estrutura interna: Segundo Weick (apud SVEIBY, 1998), a estrutura interna inclui patentes, conceitos, modelos e sistemas administrativos e de computadores, estes criados pelos funcionários, em geral pertencem a organização ou, as vezes, podem ser adquiridos em outro lugar. Além disso, a cultura ou espírito organizacional também faz parte da estrutura interna. Juntas, a estrutura interna e as pessoas constituem o que normalmente denomina-se de organização, onde as pessoas criam a organização por meio da interação mútua, desenvolvendo assim o ambiente.

Estrutura externa: A estrutura externa inclui relações com clientes e fornecedores, bem como as marcas registradas e a reputação ou a imagem da empresa. Alguns destes podem ser considerados propriedade legal, mas os investimentos na 
estrutura externa não podem ser feitos com o mesmo grau de segurança dos realizados na estrutura interna. $\mathrm{O}$ valor destes ativos é determinado basicamente pelo grau de satisfatoriedade com que a empresa soluciona os problemas de seus clientes, de modo que, nesse caso, existe sempre um elemento de incerteza uma vez que as reputações e as relações podem mudar ao longo do tempo.

Destaca-se que embora os ativos intangíveis continuem sendo fundamentais na criação de valor para as organizações, eles vêm diminuído em detrimento de um crescente aumento na parcela de valor relativo ao capital intelectual, este que nos últimos anos passou a ser um fator determinante na busca da competitividade por grande parte das empresas. Desta forma, torna-se importante conhecê-lo mais profundamente, mas antes é imprescindível, primeiro, definir seu significado.

\subsection{DEFINIÇÕES DE CAPITAL INTELECTUAL}

A pala vra capital significa riquezas ou valores disponíveis, fundo de dinheiro ou patrimônio de uma empresa. Já, intelectual significa pessoa devotada as coisas do espírito, da inteligência (MICHAELIS, 1996). Porém, a junção dessas palavras transformou-se, em curto espaço de tempo, numa importante fonte de estudos para os meios empresarias e acadêmicos tornando-se alvo de vários trabalhos contemporâneos.

É importante destacar que atualmente muitos autores são citados como referência nesta área como Stewart (1998), Edvinsson e Malone (1998), fato este inimaginável até bem pouco tempo atrás. Contudo devido a complexidade do assunto este ainda carece de mais aprofundamento teórico, por isso a importância de se buscar o maior número de informações e definições sobre o verdadeiro significado de capital intelectual, a Tabela 1 apresenta algumas destas definições.

\section{Tabela 1 - Definições de capital intelectual}

\begin{tabular}{|l|l|}
\hline Autor & Definição \\
\hline Stewart (1998) & $\begin{array}{l}\text { E a capacidade organizacional de uma empresa em suprir ou } \\
\text { mesmo superar as exigências do mercado. }\end{array}$ \\
\hline Antunes (1999) & $\begin{array}{l}\text { O (CI) e o goodwill fazem parte do mesmo fenômeno, ambos } \\
\text { verificam os elementos formadores do goodwill, que são } \\
\text { comuns aos que formam o (CI), sendo que a diferença reside } \\
\text { no fato de o goodwill englobar os efeitos da sinergia existente } \\
\text { entre todos os ativos da empresa, e o (CI) propor apenas a } \\
\text { identificação de todos os ativos intangíveis da organização. }\end{array}$ \\
\hline
\end{tabular}




\section{Tabela 1 - Definições de capital intelectual}

\begin{tabular}{|l|l|}
\hline Autor & Definição \\
\hline Sullivan (1999) & $\begin{array}{l}\text { E constituído por pessoas, experiências da empresa, invenções, } \\
\text { tecnologia, conhecimento geral, programas de computador, } \\
\text { habilidades e criatividade. Tudo que possa se converter em } \\
\text { lucros. }\end{array}$ \\
\hline Michael e Koenig (2000) & $\begin{array}{l}\text { O conceito de (CI) é simples, formado em sua essência por } \\
\text { perícias e informações que a organização possua e que possa } \\
\text { ser usada para criar uma vantagem competitiva. }\end{array}$ \\
\hline $\begin{array}{l}\text { Bontis, Keow e Richardson } \\
\text { (2000). }\end{array}$ & $\begin{array}{l}\text { Descreve (CI) como o valor econômico de duas categorias de } \\
\text { ativos intangíveis de uma companhia: o capital estrutural e o } \\
\text { capital humano. }\end{array}$ \\
\hline Andrade e Tomaz (2003) & $\begin{array}{l}\text { CI) é a soma de todo o conhecimento de uma empresa, é o } \\
\text { que lhe proporciona vantagem competitiva, e ele deve ser } \\
\text { entendido como criado a partir do intercâmbio dos capitais } \\
\text { humano, estrutural e de relacionamento. }\end{array}$ \\
\hline Matheus (2003) & $\begin{array}{l}\text { O (CI) pode ser definido e entendido a partir de alguns pontos } \\
\text { de vista distintos. Sob a ótica da contabilidade, o capital } \\
\text { intelectual pode ser entendido como sendo o conjunto de todos } \\
\text { os ativos intangíveis da empresa e, conforme com alguns } \\
\text { autores, como ANTUNES, STEWART, EDVINSSON e } \\
\text { MALONE, o (CI) representa todo, ou praticamente todo, o } \\
\text { Goodwill da empresa. }\end{array}$ \\
\hline
\end{tabular}

Segundo Edvinsson (1992), o caráter básico do capital intelectual possui três conclusões fundamentais:

1. O capital intelectual constitui informação suplementar e não subordinada as informações financeiras;

2. O capital intelectual é um capital não-finaceiro, e representa a lacuna oculta entre valor de mercado e o valor contábil;

3. O capital intelectual é um passivo e não um ativo.

A terceira conclusão é de especial importância, pois significa que o capital intelectual é um passivo a ser encarado de maneira idêntica ao patrimônio líquido.

Edvinsson e Malone (1998) destacam o capital intelectual como sendo inevitável porque somente ele, entre os modelos para a mensuração do desempenho corporativo, perpetua a superfície e expõe o valor real das empresas. Procedendo dessa maneira, ele restaura tanto o bom senso como a equidade que devem prevalecer na economia.

\subsection{ELEMENTOS E ESTRUTURA DO CAPITAL INTELECTUAL}


Matheus (2003) estabelece em seu trabalho um conjunto dos principais elementos formadores do capital intelectual, considerando aqueles mais encontrados e destacados na literatura (Tabela 2).

Tabela 2 - Principais elementos formadores do capital intelectual

\begin{tabular}{|c|c|c|}
\hline Capital Humano & Capital Estrutural & Capital de Relacionamento \\
\hline \begin{tabular}{l}
\multicolumn{1}{c}{ Individual } \\
Capacidade intelectual; \\
Capacidade de trabalho em \\
equipe; \\
Competência; \\
Conhecimento; \\
Criatividade; \\
Eficácia; \\
Experiência; \\
Habilidade; \\
Liderança; \\
Motivação; \\
Pró-atividade; \\
Relacionamento interpessoal \\
(Capacidade de). \\
$\qquad$ Coletivo \\
Clima organizacional \\
agradável e confortável;
\end{tabular} & \begin{tabular}{l}
\multicolumn{1}{c}{ Capital organizacional } \\
Conhecimento sistematizado; \\
Filosofia administrativa \\
incentivadora e participativa; \\
Instrumentos gerenciais \\
eficazes; \\
Sistemas de informações \\
eficazes. \\
$\quad$ Capital de inovação \\
Capacidade de promover \\
desenvolvimento e inovações; \\
Direitos comerciais e \\
contratuais; \\
Propriedade e patentes. \\
Capital de processos \\
Estruturação dos processos, \\
procedimentos e técnicas; \\
Eficiência dos processos, \\
procedimentos e técnicas.
\end{tabular} & $\begin{array}{l}\text { Conhecimento da marca pelo } \\
\text { mercado; } \\
\text { Imagem da empresa perante o } \\
\text { mercado; } \\
\text { Relacionamento da empresa } \\
\text { com seus clientes; } \\
\text { Relacionamento da empresa } \\
\text { com seus fornecedores e } \\
\text { parceiros comerciais; }\end{array}$ \\
\hline
\end{tabular}

Fonte: Adaptado de MATHEUS, L.F. 2003, p.49.

O capital humano, estrutural e de relacionamento resumem os principais elementos que formam o capital intelectual e esses elementos compõem a estrutura representada abaixo (Figura 05), proposta por Edvinsson e Malone (1998): 


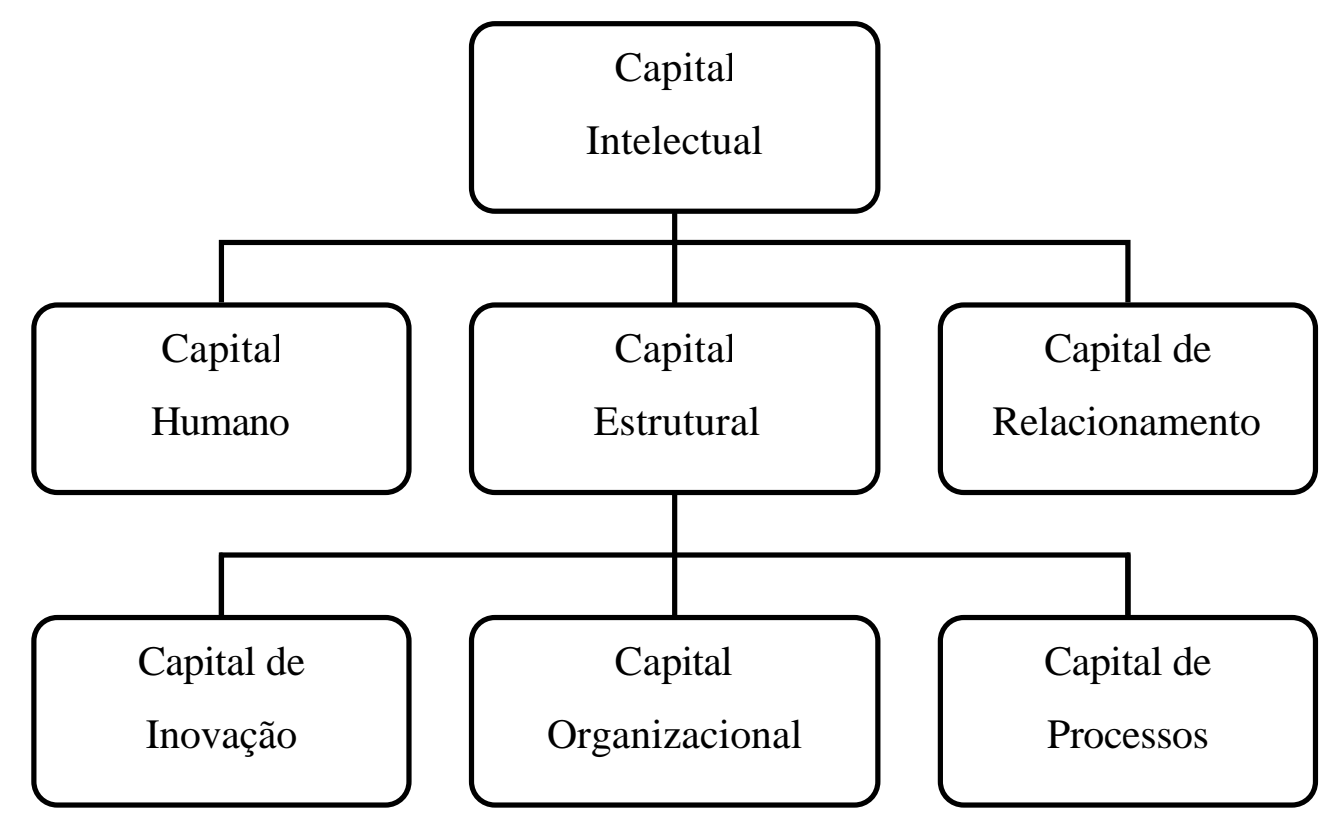

Figura 5 - Estrutura do capital intelectual.

Fonte: MATHEUS, L.F. 2003, p.45 (adaptado de Edvinsson e Malone, 1998).

A figura mostra a divisão do capital intelectual em: capital humano, capital estrutural (podendo ser subdivido em capital de inovação, capital organizacional e capital de processos) e capital de relacionamento. O capital humano relaciona-se com o conhecimento, experiência e competência dos funcionários. O capital estrutural corresponde a estrutura interna da empresa, sua capacidade de suportar e viabilizar a melhor execução dos processos e também a renovação e inovação dentro da empresa. $\mathrm{O}$ capital de relacionamento está relacionado com a qualidade dos relacionamentos da empresa com seus funcionários, fornecedores, parceiros comerciais e com seus clientes. Com Base nesta estruturação são apresentados a seguir os principais componentes formadores do capital intelectual.

\subsubsection{CAPITAL HUMANO}

Muitos autores avaliam o capital humano sob diversas óticas. Segundo Stewart (apud ANDRADE e TOMAZ, 1998), o capital humano é a capacidade que um indivíduo tem de agir em diversas situações e criar tanto ativos tangíveis como intangíveis. Este capital está muito ligado as competências individuais das pessoas.

Edvinsson e Malone (1998) afirmam que o capital humano diz respeito ao conhecimento, a experiência, o poder de inovação e a habilidade dos funcionários de 
uma companhia para realizar as tarefas do dia-a-dia. Inclui também os valores, a cultura e a filosofia da empresa, e ainda ressaltam que este capital não pode ser propriedade da empresa.

Este capital consiste nas habilidades e conhecimentos dos indivíduos dentro da organização, onde as empresas criam mecanismos de explicitá-los na busca de alcançar vantagens competitivas. Destaca-se também a importância de se conhecer, gerenciar e alinhá-lo as metas estratégicas da empresa (SULLIVAN, 1999).

Segundo Chen e Lin (2000), o conhecimento humano é que produz as riquezas e diferenças entre as empresas de hoje, e ainda que o capital humano cria mais valor que ativos tangíveis como máquinas e equipamentos.

Nerdrum (2001) destaca que o capital humano não representa somente a somatória de seus componentes, mas também as interações entre eles e a dinâmica desses elementos. Pois, as pessoas estão todos os dias vivendo novas situações, passando por treinamentos e aprendendo com outras pessoas, passando por novas experiências, adquirindo novos conhecimentos e aperfeiçoando suas habilidades e capacidades ou desenvolvendo outras.

\subsubsection{CAPITAL ESTRUTURAL}

Edvinsson e Malone (1998), afirmam que o capital estrutural é formado por equipamentos, patentes, marcas registradas e todo o resto da capacidade organizacional que apóia a produtividade, em poucas palavras tudo o que permanece na empresa quando os funcionários vão para a casa, e ainda que ao contrário do capital humano o capital estrutural pode ser possuído e, portanto, negociado.

Segundo Stewart (apud ANDRADE e TOMAZ, 1998), capital estrutural é a retenção do conhecimento para que ele se torne propriedade da empresa, este capital inclui conceitos, modelos e sistemas administrativos, bem como cultura ou espírito organizacional, estratégias, valores, competências essenciais, etc.

Sullivan (1999) destaca que o capital estrutural inclui ativos financeiros como, edifícios, maquinário e a infra-estrutura da empresa. Outros ativos empresariais complementares também são utilizados em idéias inovadoras de novos produtos e serviços. 
O capital estrutural compreende tudo aquilo que torna possível o desenvolvimento, a alavancagem e a aplicação do capital humano dentro da empresa, ou seja, ele pode ser entendido como toda a infra-estrutura que apóia o capital humano (EDVINSSON e MALONE, 1998).

Stewart (1998), afirma que o capital estrutural deve servir a dois objetivos: acumular estoques de conhecimento que sustentem o trabalho de seus funcionários e acelerar o fluxo de informação dentro da empresa.

Dentro do capital estrutural existe uma ampla extensão de elementos, por isso a necessidade de compreendê-los e dividi-los em três partes: capital organizacional, capital de inovação e capital de processos (EDVINSSON e MALONE, 1998).

Capital organizacional: abrange o investimento da empresa em sistemas, instrumentos e filosofia operacional que agilizam o fluxo de conhecimento pela organização, bem como em direção a áreas externas, como aquelas voltadas para os canais de suprimentos e distribuição.

É importante destacar que este capital compreende tudo aquilo que de fato estruture e suporte o desenvolvimento e aplicação do capital humano dentro da empresa.

Capital de inovação: refere-se a capacidade de renovação e aos resultados da inovação sob forma de direitos comerciais amparados por lei, propriedade intelectual e outros ativos e talentos intangíveis utilizados para criar e colocar rapidamente no mercado os produtos e serviços.

O capital de inovação está diretamente relacionado a tudo que propicie e garanta a capacidade de criação e renovação dentro da empresa, e que a área de pesquisa e desenvolvimento, bastante conhecida das empresas, propicia grande parte da inovação e renovação dentro da organização.

Capital de processos: É constituído por processos, técnicas e programas direcionados aos empregados, que aumentam e ampliam a eficiência da produção ou prestação de serviços. É o tipo de conhecimento prático empregado na criação contínua do valor.

Destaca-se que a formação, composição e principalmente o entendimento da estrutura formadora do capital intelectual são de extrema importância às organizações, pois um melhor aproveitamento destes recursos possibilita maior vantagem competitiva para as empresas. Porém o objetivo deste estudo é buscar compreender mais profundamente um dos elementos que constituem esta estrutura, o capital do relacionamento (Capítulo 4), este que nos últimos anos tem ocupado cada vez mais 
espaço nos meios acadêmicos e empresariais principalmente por sua significativa importância estratégica quanto a gestão de custos, qualidade e do relacionamento com fornecedores e funcionários.

\subsection{MÉTODOS DE MENSURAR O CAPITAL INTELECTUAL}

Vários autores enfatizam os benefícios proporcionados pelo capital intelectual às organizações, porém definir os mecanismos e técnicas utilizadas na medição destes benefícios é importante, pois somente com dados plausíveis sobre sua eficiência e seu respectivo retorno para as empresas é que os gestores podem dimensionar seus verdadeiros ativos organizacionais.

Segundo Petty e Guthrie (2000), para que os gestores possam gerir eficazmente o capital intelectual da empresa e maximizar seu potencial de criação de valor, torna-se fundamental não somente sua identificação e estrutura, mas também sua mensuração.

Roos (apud PETTY e GUTHRIE, 2000) destaca a importância de se mensurar o capital intelectual já que este freqüentemente diz mais sobre a capacidade de ganhos futuros da companhia do que quaisquer outras medidas convencionais de desempenho utilizadas.

A seguir serão discutidos alguns dos principais métodos utilizados pelas empresas na mensuração de seu capital intelectual.

Navegador da Skandia: considerado o primeiro modelo desenvolvido para mensuração do capital intelectual da empresa, foi desenvolvido a partir de 1985 e divulgado somente em 1994 pelo grupo Skandia, maior prestador de serviços financeiros e de seguros da Escandinávia. O desenvolvimento deste modelo foi orientado pelos então diretores da empresa (BONTIS, 2000).

Os diretores da Skandia julgavam que o resultado financeiro consistia na materialização dos esforços e realizações suportadas ou mesmo promovidas pelo capital intelectual da empresa. Porém as formas de avaliação da empresa baseavam-se somente nos resultados financeiros. Logo, era necessário desenvolver um modelo que mensurasse o capital intelectual da empresa, por ser este o principal responsável pelo desempenho financeiro da organização. Também, era necessário que este modelo 
elaborasse um relatório dinâmico que representasse fielmente as variações do capital intelectual.

Segundo Kennedy (1998), o modelo Skandia considera não só os valores nãofinanceiros do capital intelectual como também os valores financeiros, ou resultados financeiros, da empresa (Figura 6).

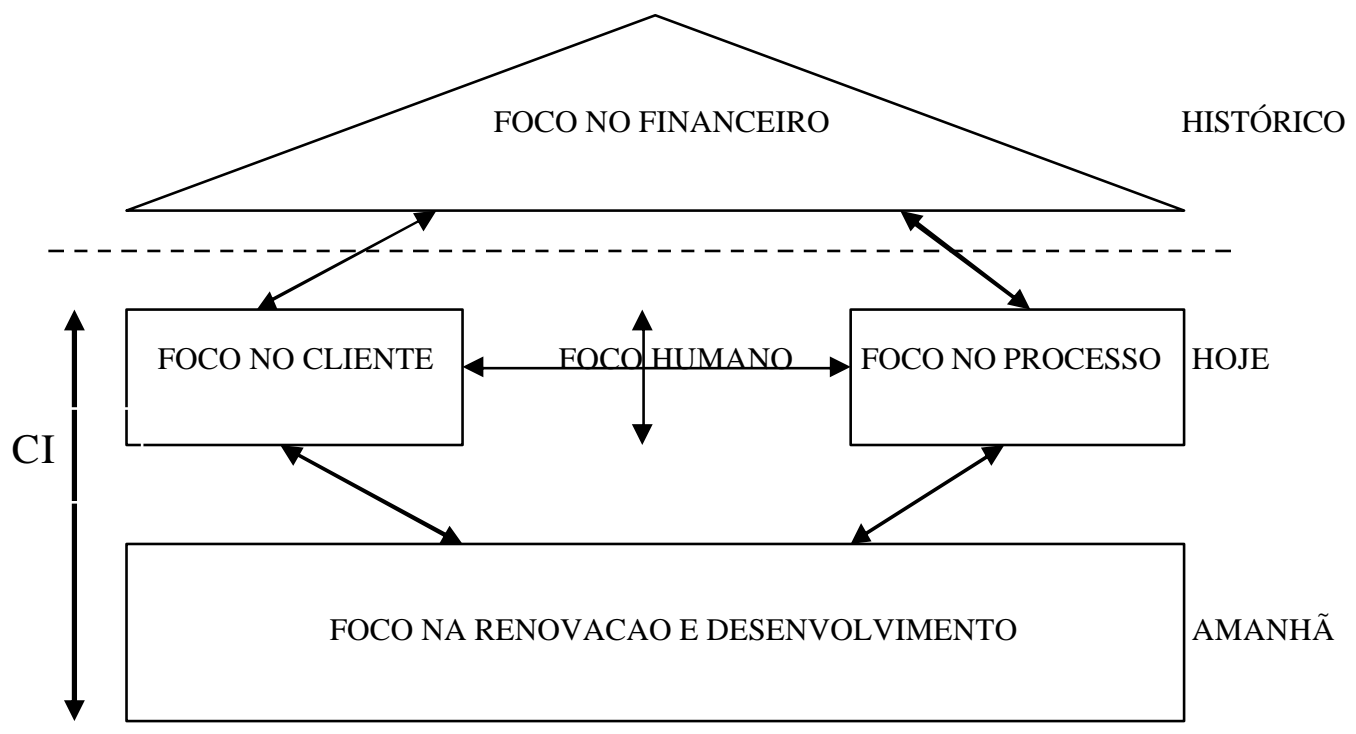

AMBIENTE OPERACIONAL

Figura 6 - Navegador skandia.

Fonte: KENNEDY, F. 1998, p.7.

Edvinsson e Malone (1998) destacam em primeiro lugar o formato do navegador, pois este não é composto por categorias de capital, mas por cinco áreas de foco, no cliente, no processo, na renovação e desenvolvimento e foco humano. Em outras palavras, essas são as áreas nas quais uma empresa focaliza sua atenção, e desses focos provém o valor de seu capital intelectual em ambientes competitivos. Os autores também descrevem cada uma das partes que compõem o modelo:

Foco financeiro: O triângulo acima do retângulo é o foco financeiro, e inclui o balanço patrimonial da empresa. Constitui o passado da empresa, uma medida exata de onde ela estava em um momento específico, os indicadores deste foco são na maioria das vezes bem conhecidos. A noção de foco, porém, permite que se agreguem novos indicadores, especialmente aqueles que denotem desempenho, rapidez e qualidade.

Foco no cliente e processo: A medida que se percorre as paredes da casa do capital intelectual, visualiza-se o presente e as atividades da empresa focalizadas nele. Estas são o foco no cliente e o foco no processo, o primeiro avaliando uma categoria 
distinta de capital intelectual e o segundo, uma parte da avaliação maior, correspondente ao capital estrutural.

Foco na renovação e desenvolvimento: $\mathrm{Na}$ base do retângulo do capital intelectual, os alicerces da casa estão voltados para o futuro, este é o foco na renovação e desenvolvimento da empresa, à outra parte do capital estrutural. Os índices nessa região medem não apenas a qualidade do preparo da empresa para o futuro, por meio de treinamentos dos empregados, desenvolvimento de novos produtos e ações semelhantes, mas a eficácia com que está abandonando o passado obsoleto pela renovação da linha de produtos, desistências de mercados decadentes e outras ações estratégicas.

Foco Humano: Encontra-se na parte central da casa, constitui o coração, a inteligência e a alma da organização. Além do mais, como única força ativa na organização, alcança todas as outras regiões do capital intelectual. Esta é a parte da empresa que retorna a seus lares todas as noites, consistindo da competência e a capacidade dos colaboradores.

Segundo Edvinsson e Malone (1998), essa estrutura do navegador permite aos administradores guiarem suas empresas, navegando por meios das áreas focadas no mesmo. Porém, para se obter bons resultados um Navegador de capital intelectual deve realizar com eficiência três tarefas:

1. Perscrutar as mensurações. Um instrumento organizador deve-se organizar para realizar suas funções;

2. Olhar para o alto, em direção a medidas mais abrangentes de valor;

3. Olhar para fora, em direção ao usuário. Isso pode parecer igualmente evidente por si só, mas a abrangência e a inclusão são muito mais fáceis na teoria do que na prática.

Não se pode presumir euforicamente que qualquer novo modelo de mensuração irá, desde o início, captar todas as informações úteis que se deseja, pois poderá levar anos até que o modelo de capital intelectual e os instrumentos necessários à sua apresentação sejam aperfeiçoados. Além do Modelo Navegador, existem outros métodos para se mensurar o capital intelectual:

Índice de CI: o índice de capital intelectual nada mais é do que uma lista com vários índices que procuram relacionar a variação do desempenho da empresa com as variações ou mudanças nos componentes de seu capital intelectual. Portanto, esse 
modelo fornece uma mensuração da relação do capital intelectual com o desempenho da empresa e não uma quantificação propriamente dita. No entanto a definição dos índices a serem utilizados, assim como seu peso, indicador e até mesmo seu julgamento, varia de empresa para empresa, de acordo com as necessidades e prioridade de cada uma (MATHEUS, 2003).

Para Bontis, Keow e Richardson (2000), este modelo apresenta-se na verdade mais como uma proposta para abordar a mensuração do capital intelectual do que como modelo de mensuração propriamente dito, pois na elaboração dos índices considera-se caso a caso, ou seja, as particularidades das empresas e suas respectivas estratégias.

Modelo Bontis: desenvolvido por Bontis (2000), estabelece um questionário contendo 63 questões para as quais as empresas deveriam responder de acordo com o nível de concordância, variando desde 1 (discordo fortemente) até 5 (concordo fortemente). É importante ressaltar que este modelo foi utilizado em um estudo realizado em 107 empresas da Malásia e que a partir das respostas do questionário, onde se buscava identificar os elementos do capital intelectual presentes na empresa e sua importância para a mesma, os pesquisadores procuraram estabelecer uma relação que comprovasse as seguintes suposições feitas por eles:

- O capital humano está positivamente correlacionado com o capital de clientes;

- O capital humano está positivamente correlacionado com o capital estrutural;

- O capital de clientes está positivamente correlacionado com o capital estrutural;

- O capital estrutural está positivamente correlacionado com o desempenho financeiro da empresa.

Desta forma nota-se que o método visa estabelecer a relação entre o capital intelectual da empresa e o seu desempenho financeiro, sem buscar, mais uma vez, quantificar este capital intelectual.

Modelo Balanced scorecard: Desenvolvido por Kaplan e Norton (1995), se baseia no questionamento das medidas estruturadas em indicadores financeiros, para propor um modelo de mensuração de desempenho de empresas estruturada também nos 
indicadores não-finaceiros. Estes formados basicamente em métricas relacionadas a satisfação do cliente, renovação e desenvolvimento, produtividade e capacitação interna. A partir destas métricas não-financeiras, relacionadas ao capital intelectual, pode-se estabelecer relações com métricas financeiras que busquem indicar a influência do capital intelectual no desempenho financeiro da empresa.

Brennan e Connell (apud PETTY e GUTHRIE, 2000), destacam que as limitações dos modelos financeiros existentes para se mensurar o capital intelectual das empresas motivaram vários pesquisadores a buscarem incessantemente solucionar este problema. Autores como Sveiby, Edvinsson, Malone, Kaplan e Norton, contribuíram muito neste sentido, pois seus estudos propiciaram um melhor entendimento dos recursos envolvidos na mensuração do capital intelectual, conforme Tabela 3.

Tabela 3 - Classificação das estruturas dos modelos que mensuram o capital intelectual

\begin{tabular}{|l|l|l|}
\hline Desenvolvido por & Estrutura & Classificação \\
\hline Sveiby (1997; 1998) & Monitorar recurso intangível & $\begin{array}{l}\text { Estrutura interna } \\
\text { Estrutura externa } \\
\text { Competência das pessoas }\end{array}$ \\
\hline Kaplan e Norton (1992) & Balanced scorecard & $\begin{array}{l}\text { Perspectiva interna dos } \\
\text { processos } \\
\text { Perspectiva do cliente } \\
\text { Perspectivas de aprendizagem } \\
\text { e crescimento } \\
\text { Perspectiva financeira }\end{array}$ \\
\hline Edvinsson e Malone (1997) & $\begin{array}{l}\text { Skandia Valor Esquema } \\
\text { Classificação de recursos }\end{array}$ & $\begin{array}{l}\text { Relação de competência } \\
\text { Capital humano } \\
\text { Capital estrutural }\end{array}$ \\
\hline
\end{tabular}

Fonte: PETTY e GUTHRIE, 2000, p.5.

É importante destacar que apesar destes modelos serem constituídos em sua essência dos mesmos elementos que compõem o capital intelectual, capital humano, capital de clientes e capital estrutural, suas classificações são abordadas de formas bem distintas uma das outras.

\subsection{GESTÃO DO CAPITAL INTELECTUAL}


Rodrigues, Antunes e Dutra (2003) concordam ser necessário administrar o capital intelectual das empresas, deve-se encontrá-lo, armazená-lo, vendê-lo, e compartilhá-lo, e que conseguir realizar esta seqüência se constitui no maior desafio vivido por indivíduos e empresas atualmente.

Sveiby (1998) aborda a gestão do capital intelectual por meio da competência, das estruturas interna e externa e com o enfoque de avaliação dos ativos intangíveis. Considera também que a principal atividade na organização do conhecimento é a transferência deste conhecimento.

Segundo Edvinsson e Malone (1998), o modelo do Navegador Skandia torna bem claro que o capital intelectual é mais do que a simples gestão do conhecimento ou propriedade intelectual. A gestão do capital intelectual é, na realidade, a alavancagem da combinação entre o capital humano e capital estrutural. A partir daí pode-se inferir que a gestão eficaz do capital intelectual é o resultado de um processo de quatro etapas:

1. Compreender aqueles componentes do navegador que demonstrem ter capacidade para a criação e obtenção de valor;

2. Alavancar esse valor pela interação e a troca de idéias a respeito das capacidades ociosas;

3. Focalizar no fluxo e no intercâmbio das habilidades de uma organização, por meio da criação de um comitê de conhecimento, em que os tomadores de decisões podem escolher o que precisam para serem mais produtivos;

4. Capitalizar esse processo divulgando, codificando, reciclando e intercambiando seus componentes.

As vantagens desse processo são amplas e profundas, incluem uma curva de aprendizagem mais acentuada, com menor tempo de aplicação e maior valor agregado. Isto torna evidente a necessidade de gerenciar tais recursos, pois com estas informações a empresa pode redefinir suas estratégias, analisar seus pontos fortes e fracos.

Estes fatores e elementos contribuem para a criação de valor dentro da organização, logo torna-se imprescindível que os gestores das empresas identifiquem e gerenciem tais recursos em sua busca incessante de retorno financeiro.

Neste capitulo buscou-se, além de definir, estruturar, descrever métodos utilizados na mensuração e discutir a necessidade de gerenciar o capital intelectual, 
descrever também a significativa importância do capital intelectual para as empresas como elemento fundamental na criação de valor e vantagens competitiva.

É indiscutível a significativa importância do capital intelectual nos últimos anos para os meios acadêmicos e industriais, por esse motivo buscourse uma maneira de contribuir neste sentido. Contudo, referente as ramificações do conhecimento citada anteriormente, o próximo capítulo tratará de uma outra ramificação, também pouco estudada, muito importante e potencialmente significativa no retorno as organizações, o capital de relacionamento, descrevendo seu significado, detalhando os elementos que o constituem e suas características. 


\section{CAPÍTULO 4}

\section{CAPITAL DE RELACIONAMENTO}

"A credibilidade de uma companhia em um mercado em geral depende das relações por ela formadas”.

(MCKENNA, 1999).

\subsection{INTRODUÇÃO}

Para sobreviver em mercados dinâmicos as empresas necessitam desenvolver novas formas de relacionamento, precisam estabelecer estratégias que possibilitem sobreviver as mudanças turbulentas do ambiente.

Segundo McKenna (1999), as companhias hoje não podem concentrar-se somente em promoções e publicidade, elas devem compreender a estrutura de seus mercados e criar as condições para o desenvolvimento de relações estratégicas. Várias razões justificam a necessidade das organizações aprofundar e também formar relações com seus fornecedores, distribuidores, investidores e clientes:

- Para competir nos mercados de hoje, as companhias precisam de um conjunto diverso de tecnologias, já que dificilmente teriam condições de desenvolver sozinha todas as tecnologias necessárias;

- Os custo de desenvolvimento de novas tecnologias estão elevando-se rapidamente e para sua sobrevivência as organizações precisam compartilhar custos;

- As tecnologias estão se modificando com mais rapidez do que nunca; 
- Companhias de pequeno porte precisam adquirir perícia em administração, força em distribuição e obter capital para que fiquem em condições de competir, e as relações estratégicas podem fazer isto;

- Relações estratégicas menos tangíveis, porém de igual importância, podem aumentar a credibilidade das companhias envolvidas. Escolhendo o sócio estratégico certo, uma empresa pode ganhar credibilidade por associação.

Embora as relações estratégicas pareçam cada dia mais atrativas, existem vários desafios em sua gestão. Um do mais comuns encontrados por gestores está relacionado a construção e participação dos sócios envolvidos, decorrentes principalmente de uma comunicação insatisfatória. Por esse motivo ao se estabelecer um novo relacionamento, todas as partes envolvidas precisam ser explícitas com relação a seus objetivos e expectativas.

Segundo McKenna (1999) a gestão destas relações tornaram-se mais importantes que preços baixo, promoções ostentosas ou mesmo tecnologia avançada, pois mudanças no mercado podem alterar rapidamente os preços e as tecnologias, já as relações próximas, porém, podem durar a vida inteira.

É importante destacar-se também que a busca por vantagens competitivas tem conduzido empresas e gestores a um novo modelo de relacionamento, com atenção especial destes aos agentes ambientais que interagem de forma direta ou indireta em seus negócios. Porém, não basta apenas estar mais atendo ao seu ambiente, é imprescindível primeiramente conhecer o significado e as características dos elementos ambientais que interagem dentro deste capital e, para melhor entender sua importância a seguir se discutirá a definição do capital de relacionamento e seus tipos.

\subsection{CAPITAL DE RELACIONAMENTO}

Segundo Stewart (apud ANDRADE e TOMAZ, 1998), capital de relacionamento é a estrutura de conhecimento das organizações com as quais a empresa faz negócios, seus parceiros estratégico, fornecedores e clientes, ou seja, é o conhecimento que deve ser utilizado para que a entrega do produto seja feita de forma completa. Quanto melhor esse relacionamento, maior a probabilidade do comprador 
dividir seus planos com o vendedor, ou seja, maior a probabilidade de uma empresa aprender com seus clientes, fornecedores e outras empresas.

Os mesmos autores destacam que o conhecimento compartilhado é a forma máxima do capital de relacionamento e que esta estrutura de conhecimento gera um ativo intangível, que é o valor desse relacionamento refletido no valor de marca, da imagem da empresa.

Conforme Edvinsson e Malone (1998), o capital de relacionamento, também definido por ambos como capital de clientes, sugerem que o relacionamento de uma empresa com seus clientes é distinto das relações mantidas com os empregados e parceiros estratégicos, e que esse relacionamento é de importância fundamental para o valor da empresa.

Para Cavalcanti, Baldam e Valle (2002), o capital do relacionamento é aquele que valoriza e incentiva uma empresa a estabelecer alianças estratégicas com clientes, fornecedores, sindicatos, governo, instituições financeiras, competidores, meios de comunicação e grupos de interesse para ampliar sua presença no mercado.

Parte da literatura restringe este capital ao relacionamento das empresas com seus clientes. Porém, os autores definem capital de relacionamento como a rede de relacionamentos de uma organização com seus clientes, fornecedores e parceiros, sendo que esses relacionamentos podem ser individuais ou institucionais. Tanto um quanto outro possuem valor e precisam ser gerenciados, por isso as empresas devem determinar os relacionamentos-chave para o sucesso de seu negócio. O passo seguinte é construir uma estratégia de relacionamento com cada um deles de forma clara e direta.

O capital de relacionamento pode agregar valor ao seu negócio de várias maneiras. Primeiramente, o retorno financeiro é foco principal da maioria das empresas, depois o retorno de imagem onde este possibilita a abertura de novas portas à organização e por último, e não menos importante, o retorno na qualidade, pois clientes exigentes exigem produtos de melhor qualidade.

Segundo Bontis (2000) este capital inclui todos os ativos de conhecimento acumulados pelo empreendimento, juntamente com suas relações com outros agentes no mesmo ambiente. Este conceito na verdade surge do aprofundamento do capital de cliente, com o objetivo de analisar o conhecimento obtido por todos os tipos de relações com competidores, fornecedores, associações, governo ou outras organizações que interagem no ambiente organizacional. 
Conhecer as características, os conceitos e os elementos formadores desses relacionamentos são de extrema importância para as organizações. Contudo, destaca-se também a relevância em se analisar o tipo de relacionamento com que estas organizações estão trabalhando, pois este deve estar adequado as suas necessidades para uma maior eficiência gerencial e operacional.

\subsection{TIPOS DE RELACIONAMENTO}

Identificar as atividades de valor com maior relevância em uma organização irá auxiliar na definição e estabelecimento de elos de relacionamentos interno entre as atividades que podem resultar em diferenciais operacionais importantes, aprimorando seu desempenho ou mesmo sua competitividade conforme o caso. Estes elos, quando identificados e explorados adequadamente, trazem ganhos de custo ou diferenciais ao produto ou serviço no final da cadeia que ajudam a promover uma sustentabilidade consistente das organizações em longo prazo (SOUZA, 2004).

Tão importante quanto os elos internos, são os relacionamentos externos que desempenham função fundamental no processo de estabelecer relações que em alguns casos se desenvolvem como parcerias. Os elos externos são a materialização de uma necessidade que se impõe na era do conhecimento como fator determinante para a subsistência de todos os tipos de organizações, pois a complexidade inerente da atual sociedade conduz a uma intrincada rede de relacionamentos onde o impacto num dos elementos afeta o outro de forma quase imediata.

Segundo Slack (1997) o relacionamento entre os elos de uma cadeia de suprimentos deve ser examinado mais detalhadamente em termos dos fluxos entre as empresa envolvidas, e destaca ainda os diferentes tipos de relacionamentos existentes e mais encontrados nas organizações:

Hierarquia integrada. É uma empresa totalmente integrada verticalmente, que engloba todas as atividades da cadeia de suprimentos, desde a fonte de matériaprima até a distribuição ao cliente final, assim como todas as atividades de suporte a cada unidade produtiva.

Semi-hierarquia. Numa organização semi-hierarquica, as empresas na cadeia de suprimentos são de propriedade de uma mesma empresa, ou são parte de um mesmo grupo, mas operam como unidades de negócios separadas. 
Co-contratação. Termo usado para descrever alianças entre organizações que tem relacionamento de longo prazo, mas que por várias razões não se fundem, embora troquem alguns valores como tecnologia, pesquisas, informações, assim como bens e serviços. Um tipo de co-contratação que tem recebido atenção significativa é a chamada parceria.

Para Slack (1997) as organizações podem estabelecer parcerias por diferentes razões. Uma razão pode ser a de transferir uma atividade de uma organização para a parceira, porque ela pode ser realizada mais eficientemente pelos parceiros juntos ou por um parceiro sozinho.

Lamming (1993) destaca que a percepção ocidental de parceria é errônea, pois se baseia na lucratividade e na redução de custos, enquanto que a filosofia da parceria deveria estar baseada no aprimoramento da produtividade e da eficiência.

$\mathrm{Na}$ parceria o frnecedor é uma parte interessada na empresa do cliente. A parceria é um processo de longo prazo e não deve ser vista como um exercício momentâneo de redução de custos, mas, ao invés disso, como um investimento onde os retornos futuros são possíveis, mas somente no médio e longo prazo (KANTER, 1989).

Slack (1997) destaca também alguns dos elementos de troca na co-contratação, conforme Figura 7.

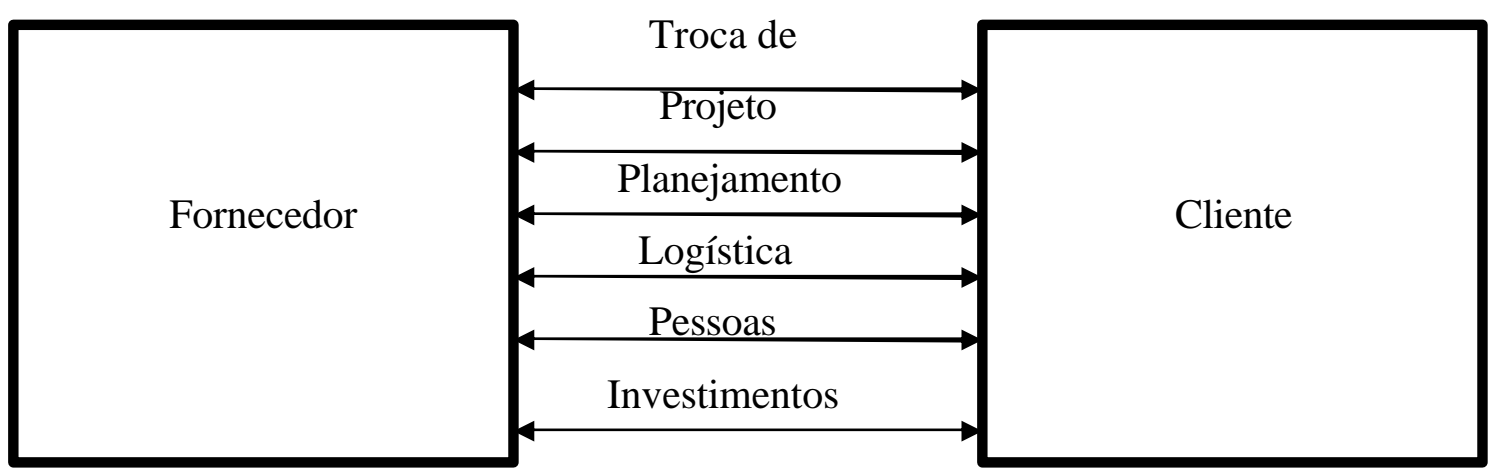

Figura 7 - Elementos da co-contratação.

Fonte: Slack (1997), p. 433.

Estes elementos são importantes na busca da construção de parcerias tendo como princípio os interesses envolvidos durante este processo para cada participante, como o compartilhamento dos riscos e recompensa, redução dos custos, o aprimoramento na entrega e na qualidade, juntamente com a ampliação de vantagem competitiva sustentada. 
Contratação coordenada. Para Kanter (1989), contratação coordenada envolve um contratante principal que emprega um conjunto de sub-contratados, como exemplo o autor sita uma construtora. $\mathrm{Na}$ relação de contratação coordenada o contratante normalmente fornece as especificações e instruções para a produção dos produtos e serviços que serão fornecidos.

Elos de receita coordenada. Esta categoria é utilizada principalmente para licenciamento e franqueamento e é uma forma de relacionamento que transfere propriedade para outra empresa, normalmente menor, mas mantendo ainda uma garantia de receita vinda do licenciamento ou franqueamento (SLACK, 1997). O mesmo autor ressalta que uma das coisas mais significativas que une as partes nesse tipo de relacionamento é o contrato, que normalmente especifica:

- Direito de propriedade sobre o produto ou serviço, que normalmente é mantido com o licenciador/franqueador;

- Região na qual o licenciado ou franqueado pode operar;

- Especificação do produto ou serviço;

- Especificação do processo a ser usado na produção;

- Processo de monitoramento do desempenho e qualquer ação que possa resultar de desempenho ruim.

Este tipo de relacionamento é comum em muitos serviços, especialmente naqueles em que o contato com o cliente é freqüente.

Comprometimento comercial de médio e longo prazo. Não é comum que empresas mantenham laços comercias por um longo prazo sem o estabelecimento de contratos formais. Porém, quando há este tipo de relacionamento comercial, pode-se estabelecer algum comprometimento que vai além de cada fornecimento. Um exemplo é o pedido programado onde o contratante se compromete a comprar um volume de produção em certo período de tempo por um determinado preço.

Comprometimento comercial de curto prazo. Em situações em que não há nenhum compromisso além de um determinado pedido, tudo o que é transferido entre as partes na transação são o pedido numa direção e os materiais e serviços em outra. Relacionamento de curto prazo são utilizados quando novas empresas são consideradas para um relacionamento mais duradouro. 
A natureza dos relacionamentos entre os diferentes elos numa cadeia de suprimentos pode ser vista como um contínuo, que vai desde a alta integração, num extremo, até os compromissos comercias temporários e de curto prazo no outro.

\subsection{PADRÔES DE RELACIONAMENTO}

Com base nos investimentos feitos em ativos específicos (tangíveis e intangíveis) tanto por fornecedores quanto por compradores, Bensaou (1999) destaca quatro padrões de relacionamento entre empresas:

Trocas no mercado: representa um grupo de relacionamentos nos quais nenhuma das partes tem desenvolvido ativos específicos para trabalhar com a outra. Este tipo de relacionamento é apropriado para produtos não sujeitos a inovações tecnológicas ou freqüentes mudanças de design. Produtores podem facilmente achar muitos fornecedores com capacidades de engenharia, produção e entrega de um mesmo tipo de produto.

Comprador cativo: consiste em relacionamentos assimétricos nos quais o comprador se mantém refém de um fornecedor que é livre para passar a vender para outro consumidor. Estes relacionamentos envolvem componentes complexos que requerem algum grau de customização, mas que são ainda baseados em tecnologia bem conhecida e estável. O mercado de suprimentos é altamente concentrado, com poucos fornecedores grandes e bem estabelecidos.

Fornecedor cativo: neste relacionamento também assimétrico, o fornecedor realiza altos investimentos para ganhar e manter negócios com o consumidor. Envolve produtos altamente complexos baseados em nova tecnologia, desenvolvida pelo próprio fornecedor, o qual deve realizar pesados investimentos em capital. No entanto, os compradores costumam mudar rapidamente de fornecedor conforme a tecnologia evolui e outros fornecedores comecem a oferecer melhorias na funcionalidade e desempenho do produto. Assim, apesar da propriedade tecnológica, o fornecedor tem poder de barganha limitado.

Parcerias estratégicas: neste caso, tanto o comprador quanto o fornecedor investem bastante no relacionamento. Os parceiros regularmente trocam informações por meio de relatórios, regras padronizadas, procedimentos, contatos face-a-face, dentre outros. Compradores trocam dados com fornecedores eletronicamente e engenheiros do 
fornecedor visitam a planta do comprador. O comprador realiza esforços para coordenar tarefas e engajar o fornecedor. O clima social é confiável e colaborativo.

Conforme Bensaou (1999), para que as firmas consigam gerenciar eficientemente suas cadeias de suprimentos, elas devem escolher um tipo de relacionamento apropriado para cada produto, mercado e condições de fornecimento. Além disso, faz-se necessário adaptar as práticas de gestão para o relacionamento particularmente escolhido.

\subsection{RELACIONAMENTO COM CLIENTES}

A globalização tem transformado os clientes em clientes globais, com desejos, necessidades e expectativas também globalizados. Hoje, os clientes estão por toda parte, procurando o que há de melhor em serviços e produtos.

Cobra (2001) afirmar que a globalização da economia trouxe para as empresas a oportunidade de ampliar sua base de negócios em dimensão internacional, mas, de outra parte, isso intensificou a concorrência em todos os mercados.

O mesmo autor destaca que cada serviço oferecido ao mercado deve combinar aspectos tangíveis, perfeitamente identificados e valorizados pelos consumidores, com aspectos intangíveis, que as pessoas não vêem, mas que contenham uma vasta quantidade de prêmios, visando agregar aos seus serviços um atendimento que encante os clientes levando-os, se possível, ao deslumbramento.

Ribeiro (2005) destaca que essa atuação global das empresas levam-nas a uma organização ramificada em todo o mundo, formando teia de pequenas empresas, altamente especializadas em seu negócio, sendo essa teia constituída através de parcerias, associações e terceirização. De certa forma, isso leva a maior proximidade com os clientes reais e potenciais que se encontram em qualquer parte do mundo.

Essas mudanças fazem com que a cultura empresarial seja adaptada quando o cliente vier em primeiro lugar nas prioridades do negócio, pois o cliente não está preocupado com estrutura administrativa, financeira ou plano estratégico, mas sim, com o valor que a empresa pode lhe oferecer. Assim, a partir do momento que a empresa passa a funcionar com o foco no cliente, ela consegue se conduzir para resultados e modelo cultural que promova essa transferência de valor e para um atendimento que seja cem por cento (HAMMER, 1997). 
Normalmente um cliente satisfeito mantém com a empresa um relacionamento saudável, de longa duração, onde ele e a empresa, de alguma forma, são o tempo todo beneficiados.

Hammer (1997) descreve com muita clareza o perfil do cliente satisfeito, atribuindo a ele os seguintes aspectos:

- permanece fiel por mais tempo;

- compra mais à medida que a empresa lança novos produtos ou aperfeiçoa produtos existentes;

- fala favoravelmente da empresa e de seus produtos;

- dá menos atenção a marcas e propagandas concorrentes e é menos sensível a preço;

- oferece idéias sobre produtos ou serviços à empresa;

- custa menos para ser atendido do que novos clientes, uma vez que as transações são rotinizadas.

A partir dessa ótica, as empresas necessariamente têm que buscar a capacitação que lhes garantirá conquistar dos clientes a sua preferência e, para tanto as empresas devem estar prontas a oferecer diferentes combinações de meios, lugares e

preços. É importante elucidar que os clientes normalmente não compram 'coisas', eles compram ferramentas para solucionar problemas ou atender necessidades. As empresas que conhecem bem os problemas de seus clientes são capazes de ajudá-los mais facilmente a encontrarem soluções do que aquelas que conhecem o equipamento apenas.

As organizações não devem se ver e atuar como produtoras de bens e serviços, mas como empreendedoras voltadas para a satisfação dos clientes. Afinal, os clientes são os maiores ativos da empresa, e hoje não se satisfazem somente com produtos de qualidade, mas estão se tornando cada vez mais exigentes quanto aos serviços prestados.

\subsection{GESTÃO DO RELACIONAMENTO DOS CLIENTES (CRM)}

Segundo Silva Filho e Monteiro Junior (2004), conscientemente ou não, as empresas dividem seus clientes em grupos de maior ou menor valor para seu negócio, e os dividem novamente com base em suas necessidades e desejos. Dessa forma, 
personaliza-se serviços e produtos para adequá-los às necessidades e ao valor de cada cliente. Esta nova tendência, conhecida por Customer Relationship Management (CRM), requer que as empresas mudem sua visão de marketing voltada para seus produtos ou serviços e voltem-se para o cliente, buscando através de interações conhecer suas necessidades e preferências.

Peppers e Rogers (1999) destacam que o CRM pode ser entendido como uma estratégia que permite à empresa ter uma visão única e integrada de seu cliente. Para isto, é necessário alinhar os objetivos do CRM com o planejamento da empresa.

Gestão do relacionamento com o cliente é um processo que gerencia as interações entre a empresa e seus clientes e que os principais usuários desses processos são os profissionais de database marketing, que estão sempre em busca de automatizar o processo de conhecimento sobre a interatividade com os clientes (BERSON, SMITH E THERDING, 1999).

Os mesmos autores ressaltam também que o objetivo da gestão do relacionamento com o cliente é a otimização da lucratividade e, reconhecer que o cumprimento desse objetivo começa com a compreensão de que nem todos os clientes tornam-se clientes da mesma maneira é um grande passo. Somente as empresas que compreendem essa premissa estarão próximas de atingirem a fidelidade de seus clientes.

Segundo Newll (2000) o segredo do relacionamento com o cliente é "ouvir e aprender", e não "falar e vender". Consiste em delegar poder aos clientes e encantá-los, para que acreditem que sua interação com a empresa está sendo controlada por eles.

Dugan (2000) argumenta que as ferramentas CRM cobrem uma gama de serviços que fornecem desde a capacidade de identificar os padrões de compra de clientes individualmente até a monitoria de pedidos. O CRM não é ferramenta gerencial nova, mas com a evolução recente da Internet sua dinâmica foi alterada radicalmente. $\mathrm{Na} W e b$, os consumidores esperam encontrar mais recursos, como rastreamento de pedidos, arquivos de auto-ajuda, um processo mais fluente para fazerem pedidos.

Esta proposta assegura muito mais do que uma simples premissa da operação de Marketing de qualquer empresa que utiliza ou venha utilizar essa ferramenta, esse aprendizado é necessário para que ela desenvolva meios de ampliar suas ofertas de valor ao mercado, pois, do ponto de vista estratégico, agregar valor às interações com os clientes é um fator de vantagem competitiva.

É importante destacar que a gestão do relacionamento com o cliente possui aspectos bastante globais, ou seja, podem ser aplicados a diversas indústrias sem 
nenhuma alteração em seu entendimento. Esta nova estratégia de administrar clientes busca otimizar seu valor em longo prazo.

Os métodos tradicionais de atrair clientes estão se tornando ineficazes, pois se o cliente tem uma necessidade, ele vai satisfazê-la, mais cedo ou mais tarde e qual a empresa que vai fornecer-lhe os produtos ou serviços para satisfazer essas necessidades, do ponto de vista do cliente, é uma mera casualidade. Por isso, saber identificar a ocorrência de eventos que determinam mudanças nas necessidades é fundamental para cada vez mais participar da vida de cada cliente.

\subsection{RELACIONAMENTO ENTRE FORNECEDORES E CLIENTES INTERNOS}

Segundo Slack (1997), as expressões consumidor interno e fornecedor interno podem ser usadas para descrever aqueles que recebem output e fornecem inputs a qualquer microoperação nas organizações. Para o autor, os consumidores e fornecedores internos na verdade não deixam de ser outras microoperações que podem modelar qualquer função de produção como uma rede de microoperações que estão engajadas em transformar matérias, informações ou consumidores (isto é, funcionários). Desta forma, cada microoperação acaba sendo, ao mesmo tempo, uma fornecedora interna de bens e serviços e uma consumidora interna de bens e serviços de outras microoperações, conforme Figura 8.

Microoperação

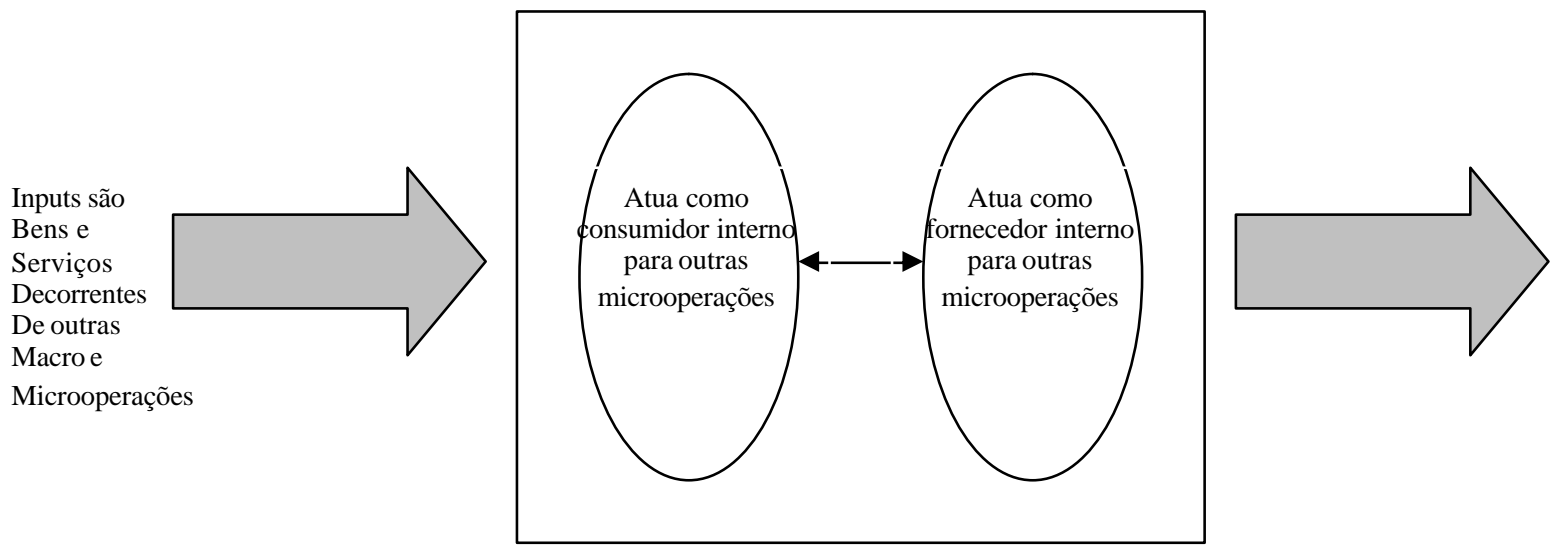

Figura 8 - Macro e microoperações: consumidores e fornecedores.

Fonte: Slack (1997), p.453. 
Entretanto não se pode tratar os consumidores e fornecedores internos exatamente da mesma forma que os consumidores e fornecedores externos, pois estes geralmente operam em mercados livres.

Segundo Kotler e Armstrong (1995), do ponto de vista empresarial, o conceito de fornecedores e clientes internos são elementos essenciais na busca de se alcançar as expectativas do cliente final, ou seja, constituem-se em uma peça fundamental na qualidade de produtos e serviços.

É importante destacar que este conceito é um lembrete útil para todas as parte de operação nas empresas que ao tratar seus clientes internos com o mesmo grau de cuidado dedicado aos consumidores externos, pode melhorar sua eficácia na operação global.

Em economias globalizadas este relacionamento não se limita somente dentro das organizações, a interação e interdependências se dá em todas as dimensões e, esta realidade tem criado condições favoráveis para um novo formato de parcerias. Este novo formato de relacionamento é discutido a seguir, baseando-se no setor automobilístico e, a justificativa pela escolha desse setor está no fato do mesmo se encontrar na vanguarda de novos métodos para alcançar a eficiência administrativa, em função da acirrada concorrência entre as montadoras de autos no Brasil.

\subsection{RELACIONAMENTO DOS FORNECEDORES COM AS MONTADORAS}

Segundo Zawislak (2001), em termos organizacionais a decisão estratégica de fazer ou comprar constitui um dilema que pode ser resumido, de certa forma, entre competir com ativos próprios ou compartilhando ativos. Dessa forma, sob o prisma dessa abordagem o foco da decisão estratégica é os custos de transação. Entretanto, muitas vezes, a decisão de uma empresa em produzir ou disponibilizar determinados insumos, componentes ou serviços necessários à realização de suas atividades produtivas transita em um sentido que ultrapassa simplesmente a preocupação com os custos de transação.

Aguiar (2002) afirma ser possível propor que a decisão de uma firma por externalizar sua produção define o resultado de uma análise estratégica voltada para a redefinição de suas competências distintivas. 
Essas duas abordagens conduzem a mudanças radicais no processo de organização das empresas, alterando as relações clientes - fornecedores, que agora, podem fundamentar-se em alianças estratégicas e integração interorganizacional.

Hamel e Prahalad (1995) concordam que estas mudanças são decorrentes da globalização da economia e vem exigindo que as organizações compartilhem investimentos e reduzam a pressão financeira, possibilitando uma forma de entrada rápida em numerosos mercados e o desenvolvimento de novas competências, sendo então importante conhecer como se configuram as relações cliente - fornecedor.

Segundo Salerno (2003), no caso da indústria automobilística mundial esta tem passado por um processo de importantes transformações que vai muito além da adição da filosofia e das práticas abarcadas pela "produção enxuta". Basicamente tais mudanças ocorrem em três grandes frentes: reestruturação interna da produção, através das adoções das práticas enxutas; configuração de novas relações de fornecimento, devido à formação dos blocos de comércio regionais e à introdução de novos arranjos organizacionais (modular, condomínio industrial, etc.); e mudanças nas atividades de projeto de produto, através das tecnologias CAD/CAM/CAE e da introdução do conceito de carro mundial.

No Brasil, tais alterações têm sido destacadas pela instalação de novas montadoras e pela modernização das já existentes (ALVES FILHO, 2002). No contexto da segunda frente de mudança citada acima, o autor também ressalta o impacto que estes investimentos têm trazido nos arranjos das cadeias de suprimentos e na alteração do relacionamento montadora - fornecedor.

Segundo Alves Filho (2000) as montadoras de automóveis ganharam poder em relação aos fornecedores de autopeças. Com esse poder acumulado e comandando os investimentos feitos, as montadoras puderam definir, em grande parte, as configurações das cadeias industriais no setor. Destaca ainda que as configurações das cadeias produtivas foram sendo definidas nas negociações das montadoras com seus fornecedores principais, especialmente nas ocasiões em que novas plantas estavam sendo instaladas.

Um dos alvos de mudanças nas estratégias das montadoras de veículos, de longe o elo mais forte de sua cadeia produtiva, são as relações entre essas empresas e seus fornecedores. Não sem razão, estima-se que os componentes e peças sejam responsáveis por $60 \%$ a $75 \%$ do valor agregado e do custo final de um veículo e, 
portanto, melhorias nesse sentido podem significar diminuições de custo para os fabricantes de veículos e componentes (POSTHUMA, 1997).

No contexto desta transformação pode-se observar também impactos significativos nas unidades montadoras de motores das empresas fabricantes de automóveis. Fenômenos como os motores de $1000 \mathrm{cc}$ e as joint-ventures para produção conjunta de motores também trouxeram implicações significativas para os relacionamentos na cadeia de suprimentos destas empresas.

Robles (2001) destaca a importância do setor automobilístico construir alianças estratégicas em sua cadeia de suprimentos priorizando a gestão de relacionamento entre fornecedores e clientes. Outros autores destacam casos aplicados em algumas destas indústrias, como a Ford Camaçari que levou grande parte de seus fornecedores a esta região e a Volkswagen Caminhões e Ônibus, operações América do Sul localizada em Resende - RJ, que utilizou o então inédito consórcio modular.

Segundo Roberti (2001), no consórcio modular o fornecedor instala-se dentro da planta da montadora, e realiza não só a entrega de seu subconjunto como também a montagem do produto final.

O mesmo autor destaca que o conceito de "fornecedores como parceiros" visava alcançar diminuição de custos variáveis e fixos, além de diminuição do investimento, já que tanto a operação de montagem quanto as instalações para a montagem seriam responsabilidade do "parceiro", que definiriam também aspectos como lay-out do processo de seu módulo, sua rede de fornecedores e logística. Segundo o projeto, à VW caberiam as áreas de engenharia de produto, controle de qualidade através do 'mestre', funcionário especializado da montadora que acompanha todas as etapas de montagem nos módulos e atesta a qualidade, distribuição, comercialização e logística do produto final.

Para a montadora, seria uma redefinição de seu core business, que passaria a englobar somente as atividades relativas a finanças, o projeto, o desenvolvimento e a certificação de produtos e as atividades de vendas e pós-vendas. Por esse motivo, somente as áreas ligadas a essas atividades continuariam sob sua responsabilidade.

Os resultados obtidos com este sistema (consórcio modular) se configuram em vantagens e desvantagens para a montadora e fornecedores (ROBERTI, 2001).

Vantagens montadora: investimentos nas plantas compartilhado com os fornecedores; melhoria do just in time e implantação do just in sequence levando a uma diminuição dos austos de armazenagem de componentes e subconjuntos; diminuição 
dos custos de transação; melhor assistência técnica; permanece o domínio na cadeia por parte da montadora, dada a forma como o consórcio modular é projetado.

Desvantagens montadora: dificuldade de mudança de fornecedor, pois existe uma parcela de investimento dedicado que torna mais complicada a troca; riscos próprios da opção pela "fonte única", como ocorrência de imprevistos que causem descontinuidade no fluxo produtivo.

Vantagens fornecedores: garantia de demanda por um tempo relativamente longo; aprofundamento da tecnologia e aquisição de novas competências; possibilidade de agregar valor ao seu produto através do fornecimento de subconjuntos e serviços montagem, assistência técnica; elevação das barreiras de entrada de novos concorrentes.

Desvantagens fornecedores: diminuição da flexibilidade uma vez que a possibilidade de utilizar as instalações do consórcio para atender outros clientes é nula; aumento dos riscos, já que o desempenho da empresa no consórcio depende exclusivamente do desempenho da montadora; possível dificuldade em manter o equilíbrio de demanda durante o processo; maiores barreiras de saída, devido ao investimento efetuados no consórcio.

Segundo Silva e Nagano (2005), a estratégia adotada pela empresa se mostrou muito positiva sobre vários aspectos, como a diminuição de seus custos e melhores índices de qualidade. E ainda que este capital consiste na gestão da qualidade do relacionamento da empresa com seus funcionários, fornecedores, parceiros estratégicos e clientes, ou seja, todos os elementos que de uma maneira ou outra possam interferir neste relacionamento.

É importante destacar que o fornecedor ajuda no desenvolvimento do projeto do produto, na análise e melhoria do processo produtivo de seu cliente, garante a qualidade, abre sua planilha de formação de custos e preços, e em contra-partida, recebe um contrato de fornecimento por um período normalmente igual ao da vida do produto.

\subsection{MARKETING DE RELACIONAMENTO}

No contexto empresarial, cliente fiel é aquele que está envolvido e presente, aquele que não muda de fornecedor e mantém consumo freqüente, optando por uma organização em particular sempre que necessita de um determinado produto ou similar. Para Bogmann (2002), a fidelização integra o processo de marketing de relacionamento 
que abrange o cliente interno, passando pela qualidade total do serviço e atua como fator importante para a conquista do cliente externo.

Rodriguez (2002), destaca que o marketing de relacionamento com os clientes é uma estratégia de negócio, voltada para o atendimento e antecipação às necessidades e aos desejos dos clientes atuais e potenciais, fazendo com que toda a empresa trabalhe orientada aos clientes.

Segundo Bogmann (2002), o marketing de relacionamento é essencial ao desenvolvimento da liderança no mercado, à rápida aceitação de novos produtos e serviços e à consecução da fidelidade do consumidor. Para o autor, a criação de relações sólidas e duradouras é tarefa árdua, de difícil manutenção e uma relação pessoal é a única forma de manter a fidelidade do cliente. Explica também que os princípios de marketing de relacionamento derivam dos princípios básicos de marketing, ou seja, análise das oportunidades de mercado; seleção dos consumidores alvo; desenvolvimento do mix de marketing e administração do esforço do marketing.

Já Kotler (1997) afirma que o marketing de relacionamento significa criar, manter sólidos relacionamentos com os clientes e outros públicos, ao invés de elaborar mixes de marketing que gerem venda e novos clientes, a melhor linha de defesa é a manutenção de clientes através do oferecimento de satisfação e valor, que resultam em forte lealdade.

A criação e a continuidade de um relacionamento depende dos benefícios que ele trouxer, segundo a percepção dos clientes. Em outras palavras, a continuidade do relacionamento dependerá da capacidade da empresa em elaborar estratégias que impeçam a descontinuidade do relacionamento (SHETH E PARVATIYAR, 2000).

Bogmann (2002) destaca que o marketing de relacionamento deve funcionar como um novo conceito, cujo resultado depende do comprometimento dos dirigentes da empresa e de todos os funcionários, e deve ser definido no planejamento estratégico da empresa. O planejamento estratégico é um processo que determina os objetivos básicos da organização, posteriormente adotando cursos de ação que os realizem e tem um impacto vital no destino da organização, porque fornece orientações em longo prazo para as pessoas que decidem sobre os destinos da empresa. Assim sendo, o planejamento estratégico do marketing deve ter como objetivo a fidelização dos clientes, prospecção de novos clientes, venda direta, dentre outros. 
Segundo Kotler e Armstrong (1995) ao tratar-se do tema Marketing de Relacionamento, não se pode deixar de abordar os tipos de relacionamentos que se constroem através das relações criadas entre a empresa e o cliente, conforme Tabela 4.

Tabela 4 - Níveis de relacionamento com clientes

\begin{tabular}{|l|l|}
\hline Básico & $\begin{array}{l}\text { O vendedor vende o produto, mas não faz qualquer acompanhamento } \\
\text { posterior }\end{array}$ \\
\hline Reativo & $\begin{array}{l}\text { O vendedor vende o produto e incentiva os clientes a ligarem sempre que } \\
\text { tiverem algum problema ou dúvida. }\end{array}$ \\
\hline Confiável & $\begin{array}{l}\text { Após a venda, o vendedor liga para verificar se o produto satisfez suas } \\
\text { expectativas ou se houve decepção; pede sugestões para melhorar o } \\
\text { produto, ajudando a empresa a aperfeiçoar continuamente suas ofertas. }\end{array}$ \\
\hline Pró-ativo & $\begin{array}{l}\text { O vendedor ou outras pessoas da empresa ligam para o cliente de tempos } \\
\text { em tempos com sugestões sobre o melhor uso do produto ou novos } \\
\text { produtos úteis. }\end{array}$ \\
\hline Parceria & $\begin{array}{l}\text { A empresa trabalha continuamente com o cliente para identificar meios de } \\
\text { oferecer melhor valor. }\end{array}$ \\
\hline
\end{tabular}

Fonte: Kotler e Armstrong (1995)

O relacionamento que floresce entre uma empresa e seus clientes é do tipo aberto e responde às necessidades evolutivas. À medida que os clientes se modificam, a empresa se modifica; à medida que a empresa modifica, modificam-se igualmente os hábitos de compra dos clientes. Esse relacionamento dinâmico, constantemente mutável e evolutivo, resulta em maiores negócios para a empresa e melhores produtos e serviços para os clientes (GRIFFIN, 1998).

Neste capítulo buscoutse evidenciar a importância do capital de relacionamento para as organizações, onde a busca em se gerenciar este ativo intangível de maneira mais eficiente pode levar as empresas a ganhos significativos.

É importante destacar que a construção dos capítulos 2, 3 e 4 serviram como pilares de sustentação ao objetivo principal desta pesquisa, que procura enfatizar a importância do capital de relacionamento para as organizações. Em continuidade ao trabalho, o capítulo a seguir se refere a metodologia de pesquisa, que abordada o aspecto principal na condução da pesquisa, detalhando todas as etapas e procedimentos utilizados na pesquisa de campo referentes ao estudo de caso proposto. 


\section{CAPÍTULO 5}

\section{METÓDO DE PESQUISA}

Este capítulo destina-se a apresentar o método do estudo empreendido no presente trabalho, abordando os objetivos da pesquisa, seu delineamento e a forma de coleta de dados, buscando justificar a escolha do método no estudo proposto.

É importante destacar que este trabalho fora dividido em duas partes, a primeira compreendendo um levantamento bibliográfico constituído pelo conjunto de pensamentos de vários autores sobre os assuntos relacionados aos temas centrais desta pesquisa: Gestão do conhecimento, Capital intelectual e Capital de relacionamento.

A segunda parte é relativa a pesquisa de campo, onde destaca-se a importância da revisão literária no desenvolvimento e conceituação das variáveis pertencentes ao tema proposto, que somadas ao protocolo de pesquisa formam o corpo principal para a coleta e análise dos resultados.

A seguir será discutido, apresentado e justificado o método para a condução da pesquisa.

\subsection{DEFINIÇÕES}

Lakatos e Marconi (2000) definem método como o conjunto de atividades sistêmicas e racionais que, com maior segurança e economia, permite alcançar o objetivo - conhecimentos válidos e verdadeiros - traçando o caminho a ser seguido, detectando erros e auxiliando as decisões do cientista.

Para Oliveira (2001), método é uma forma de pensar para chegar a natureza humana de um determinado problema, quer seja para estudá-lo ou explicá-lo.

Observando-se a necessidade e a importância de se determinar o método a ser utilizado para auxiliar o pesquisador na condução do trabalho, destaca-se então que a 
determinação da metodologia a ser adotada na solução do problema é fator fundamental para se obter sucesso de maneira produtiva e eficaz.

O presente trabalho pode ser descrito como um estudo de caso e, a justificativa para esta escolha se apresenta nos parágrafos que se seguem. Antes, porém, vale uma discussão sobre o método em questão.

Segundo Yin (1994), um estudo de caso é uma investigação empírica de um fenômeno contemporâneo dentro de seu contexto da vida real, especialmente quando os limites entre o fenômeno e o contexto não estão claramente definidos, bem como quando o número de variáveis de interesse é maior que o de pontos dados. O autor ressalta que a metodologia de estudo de caso é preferível quando o pesquisador tem pouco controle sobre os eventos e quando o foco se encontra em fenômenos contemporâneos inseridos em algum contexto da vida real.

Destaca também que a escolha do método deve-se basear na contemporaneidade do fenômeno, no tipo de pergunta da pesquisa feita, que possuem características de abordagem de termos "como" e "porque". Devido a estes questionamentos o método de estudo de caso é adequado ao presente estudo, pois além de se tratar de um fenômeno atual, sobre o qual se tem pouca possibilidade de controle, busca-se também respostas para essas perguntas.

\subsection{TIPO DE PESQUISA}

Esta pesquisa enquadra-se num estudo exploratório descritivo. Mattar (1994) define uma pesquisa descritiva como aquela que tenta determinar se um fenômeno existe ou não, seja pela explicação do fenômeno em si ou pela sua correlação com algo. É uma pesquisa exploratória como aquela que examina um fenômeno para defini-lo de modo mais completo ou diferenciá-lo de outro fenômeno. Ressalta ainda que os resultados deste tipo de pesquisa possam mudar ao longo do tempo e que isso pode ser um fato interessante a ser utilizado.

Devido à contemporaneidade do tema e por existir pouco conhecimento organizado sobre a gestão do capital de relacionamento, pode-se classificar esse trabalho como exploratório e descritivo, pois o mesmo irá relatar as características deste relacionamento, suas alianças estratégicas e as oportunidades que este oferece para a empresa, seus fornecedores e funcionários. 
Gil (1996) explica que uma pesquisa exploratória visa proporcionar maior familiaridade com o problema, buscando torná-lo explícito ou ainda construir hipóteses sobre o tema pesquisado. Sobre os objetivos de uma pesquisa descritiva, esta busca estabelece a relação que possa existir entre as variáveis e a natureza desta relação.

O estudo de caso desta pesquisa pode ser considerado exploratório, pois existe ainda pouca compreensão sobre o fenômeno estudado e trata-se de uma situação na qual não existem resultados claros e únicos.

\subsection{PROTOCOLO DE PESQUISA}

Segundo Yin (1994), o protocolo de pesquisa de um estudo de caso propõe maior confiabilidade à pesquisa, tornando-se desejável em todas as circunstâncias, e deve ser compostos dos seguintes tópicos:

Visão geral de estudo de caso. Tal visão envolve a definição dos objetivos, os pontos principais do estudo de caso e leituras relevantes sobre o tópico investigado.

Procedimentos de campo. Que relatam todos os processo e procedimentos necessários a realização da pesquisa, considerando o roteiro de estudo, fontes de informações, pessoas entrevistadas, entre outros quesitos.

Informações gerais. Sobre os procedimentos, assim como notas para lembrar detalhes importantes.

Questionário do estudo de casos. Questionário aplicado dentro do estudo, com a finalidade de buscar resposta aos objetivos do trabalho.

É importante destacar que todos estes tópicos serão discutidos mais detalhadamente durante a construção deste capítulo.

\subsubsection{VISÃo GERAL DO PROJETO DE ESTUDO DE CASO}

Destaca-se que estes pontos já foram trabalhados e discutidos durante a revisão, faltando apenas determinar e descrever as variáveis que efetivamente compõem o estudo. 
É importante destacar que as principais variáveis formadoras do capital de relacionamento encontradas durante a pesquisa e que farão parte dos questionários elaborados para confirmação ou não dos objetivos propostos no trabalho são:

Conhecimento: Como a empresa estimula a disseminação e compartilhamento do conhecimento dentro e fora da organização? Quais ferramentas ela utiliza para conseguir administrar este importante ativo intangível?

Comprometimento: Analisar se a empresa conta com a colaboração de funcionários e fornecedores em eventuais necessidades, como alerta a falhas no processo ou produto e aumento de horas rabalhadas, esclarecendo, assim, o nível de comprometimento entre as partes envolvidas.

Relacionamento: A empresa possui indicadores e ferramentas que destaquem o nível de satisfação entre ela e seus fornecedores e funcionários, e vice versa?

Custo: A empresa possui políticas de redução de custos e estes são determinantes no desenvolvimento de novas parcerias ou projetos?

Responsabilidade: Analisar se a empresa entrega e recebe seus produtos dentro dos prazos estabelecidos e ainda se a mesma disponibiliza segurança a seus funcionários e fornecedores.

Informação: Quais as ferramentas utilizadas para divulgar seus resultados e expectativas sobre seus funcionários e parceiros e ainda se esta informação é clara e entendida pelas partes?

Qualidade: Os indicadores de qualidade melhoraram nos últimos anos e, ainda, se existe uma política com relação a certificação dos produtos recebidos?

Destaca-se que o objetivo deste trabalho é confrontar as opiniões e visões a respeito do relacionamento entre a empresa, seus funcionários e fornecedores. A seguir encontra-se a elaboração e aplicação dos questionários utilizados na pesquisa de campo, tendo como base as variáveis apresentadas acima.

\subsubsection{PRÉ-TESTE}

Para Straub (1990), a validação do instrumento é fundamental na construção de instrumentos de mensuração de atitude, uma vez que instrumentos válidos permitem maior clareza na formalização e interpretação das questões de pesquisa e, sem ela as interpretações podem estar comprometidas. 
Hair et al. (2005) destaca que a criação de um questionário é somente uma fase de vários passos da pesquisa que se encontra relacionados. Contudo, é uma fase importante porque a coleta de dados através de questionário é utilizada para melhorar a tomada de decisão, porém o pesquisador deve ter clareza quanto ao que está sendo estudado e o que se espera do estudo, isso significa que o problema da pesquisa deve ser claramente definido.

Com base nestas observações buscou-se construir um questionário utilizandose as variáveis já abordadas, com o objetivo de validar-se o estudo de caso. Desta forma, dois questionários foram elaborados, um aplicado aos funcionários da empresa e outro aos seus fornecedores, porém na etapa de validação somente os funcionários participaram, já que as questões utilizadas em ambos são praticamente as mesmas. Destaca-se também a elaboração de um roteiro de entrevista estruturada aplicado aos executivos desta empresa.

Este trabalho resultou em um questionário contendo 20 questões fechadas e agrupadas que buscam identificar a compreensão das pessoas em relação a informação requerida. Os entrevistados foram orientados a identificar itens ambíguos, não claros e confusos. Solicitou-se, também, que os mesmos descrevessem brevemente, de forma verbal, como interpretaram cada item. Ao término de cada questionário foi disponibilizado um espaço para que as pessoas inserissem comentários e sugestões.

A escala utilizada foi de Likert, de 1 a 7 pontos, variando de discordo fortemente a concordo fortemente, com o objetivo de medir a satisfação dos funcionários com relação aos pontos focados. Durante o pré-teste foram entrevistados 10 funcionários com o perfil idêntico aos que fizeram parte da pesquisa final, minimizando desta maneira possíveis distorções, pois o grupo é heterogêneo, com diferentes visões e pensamentos. A aplicação deste teste ocorreu em 03 de fevereiro de 2006.

Os resultados obtidos com o pré-teste trouxeram algumas questões importantes na elaboração final deste trabalho.

- Observou-se a falta de alguns setores, como a manutenção;

- Foi sugerida a reformulação da questão que buscava verificar se a média salarial paga pela empresa era maior que a média paga na região. A sugestão foi que seria mais coerente relacionar esta questão a função exercida pelo funcionário, evitando distorções nos resultados; 
- Observoutse a necessidade de melhorar o layout do questionário, pois dois entrevistados não responderam a questão relativa a turno de trabalho, pelo fato de não ter sido notada;

- A empresa solicitou a retirada de uma questão por considerá-la comprometedora.

Findo o pré-teste, o questionário foi reformulado e aplicado, tanto aos funcionários quantos aos fornecedores, com algumas pequenas diferenças entre estes. Destaca-se também que as questões ficaram agrupadas em uma página mantendo o tamanho adequado para uma boa leitura.

\subsection{COLETA DE DADOS}

A unidade de análise é uma categoria importante a se definir no método de estudo de caso, e a unidade de análise deste trabalho é a Fábrica de Motores São Carlos, empresa do grupo Volkswagen do Brasil.

A população desta pesquisa compreende, portanto, seus fornecedores e funcionários. Todos os fornecedores foram convidados a participar da pesquisa e, quanto aos funcionários utilizou-se uma amostragem probabilística simples, que segundo Hair et al. (2005) minimiza assim a tendência de seleção, ou seja, todos tem a mesma possibilidade de participarem.

Determinada a unidade de análise e de amostra pode-se então detalhar as etapas de coleta de dados.

A fase de coleta de dados está dividida em etapas distintas, principalmente no que diz respeito as técnicas utilizadas, onde buscourse uma triangulação metodológica com a aplicação de técnicas qualitativas (entrevistas) combinadas com técnicas quantitativas (questionários e análise de informações no estudo de um mesmo fenômeno).

$\mathrm{Na}$ realização do estudo foram utilizados tanto dados primários como secundários correspondendo, basicamente, a aplicação de pesquisa de campo, conforme descrito a seguir: 
- Dados secundários: Segundo Gauri (apud ROBLES, 2001) estes dados têm o objetivo de obter informação sobre a empresa selecionada e sobre o ambiente de pesquisa para compor o estudo de caso. No presente trabalho os dados foram obtidos através de publicações e documentos da empresa (relatórios, circulares, jornais internos, intranet, manuais de políticas e práticas administrativas, etc.) e matérias publicadas na imprensa livre e, encontram-se no item Estudo de Caso, ao final deste capítulo;

- Dados primários: Referem-se ao levantamento dos indivíduos que se deseja pesquisar. Neste estudo, os dados primários foram obtidos através de contatos com a empresa, seus funcionários e fornecedores. Para Yin (1994), os dados primários podem originar-se de seis fontes: documentação, registro em arquivos, entrevistas, observação direta, observação participante e artefatos físicos.

Seguindo o modelo proposto por Yin (1994), as fontes utilizadas serão documentações, através de relatórios, contratos e manuais de procedimentos, e entrevistas, utilizando-se um roteiro de perguntas aplicadas em três grupos distintos:

Funcionários: $\mathrm{O}$ número de participantes escolhidos foi previamente discutido e estabelecido pela gerência da empresa, que considerou 44 o número suficiente de pessoas para a análise, representando $10 \%$ do total de funcionários.

Com o objetivo de manter a imparcialidade dos dados da pesquisa, o método de escolha dos 44 entrevistados deu-se através de sorteio realizado pelo pesquisador. Todos os funcionários ativos da empresa, descontados os afastados e os que se encontrava em férias no período, foram nominados e colocados em uma urna para a realização do sorteio. Respeitando uma amostragem de $10 \%$ para cada área ou turno pesquisado, chegou-se a seguinte separação:

- 18 funcionários do primeiro turno;

- 14 funcionários do segundo turno;

- 07 funcionários do terceiro turno;

- 05 funcionários mensalistas. 
Para os funcionários foi aplicado um questionário com 19 perguntas fechadas, agrupadas e objetivas (Apêndice A), onde se buscou identificar o grau de concordância entre os entrevistados, através das afirmações feitas no questionário, seguindo a escala de 1 (discordo fortemente) até 7 (concordo fortemente).

A utilização da escala de 1 até 7 para as resposta teve como propósito permitir uma variabilidade maior das respostas, o que, por sua vez, poderia refletir uma forma mais acurada e real da situação dos elementos investigados.

Todos os questionários foram distribuídos e recolhidos pelo próprio pesquisador com o objetivo de esclarecer quaisquer dúvidas ou receio dos entrevistados. Alguns entrevistados demonstraram que gostariam de manter o anonimato, fato este que se manteve como um dos princípios da pesquisa.

Destaca-se que a pesquisa durou exatamente quatro dias, sendo as entregas dos questionários realizadas entre os dias 15, 16 e 17 de fevereiro e o recolhimento entre os dias 17 e 18 do mesmo mês, havendo $100 \%$ de participação.

Fornecedores: Neste grupo, utilizourse um questionário com a mesma escala e similar ao dos funcionários, com 20 perguntas fechadas e agrupadas, distribuídos à todos os fornecedores de componentes e serviços da empresa (Apêndice B). Destaca-se a importância em se utilizar perguntas fechadas, pois estas permitem o tratamento estatístico das respostas, possibilitando chegar a resultados representativos do conjunto de fornecedores estudados.

O período de pesquisa neste grupo durou um mês, desde sua entrega no dia 15 de fevereiro até o recebimento final no dia 15 de março. O período de devolução dos questionários foi maior que dos funcionários pelo fato do pesquisador não possuir contato direto com os fornecedores. Inicialmente, o contato fora estabelecido por intermédio da empresa, o que contribuiu para que o grupo mostra-se maior interesse em participar da pesquisa.

Devido a distância e ao alto número de possíveis entrevistados neste gupo, não foi possível uma distribuição pessoal a cada fornecedor de produtos ou serviços, neste caso os questionários foram enviados através de e-mail, com uma carta de apresentação detalhando o objetivo acadêmico da pesquisa e principalmente o sigilo e anonimato sobre os participantes. É importante salientar que todos os contatos foram feitos com a autorização da empresa. 
Foram enviadas 110 mensagens eletrônicas, correspondendo a todos os fornecedores da empresa. Porém, somente 19 fornecedores responderam, equivalendo a pouco mais de $10 \%$ do montante, mas já o suficiente para a realização de um trabalho com caráter exploratório.

Executivos da Empresa: Neste grupo, diferentemente dos anteriores, não se utilizou a aplicação de questionário com perguntas fechadas e agrupadas, mas sim o método de comunicação, com utilização de um roteiro de perguntas semi-estruturadas e não-disfarçadas, aplicados aos executivos da empresa (Apêndice C).

A escolha destes profissionais teve como propósito buscar pessoas que tivessem um conhecimento amplo e profundo sobre toda a organização, principalmente no tocante as práticas administrativas e financeiras da empresa. Destaca-se que as entrevistas com os executivos não puderam ser gravadas, pois obedeceu-se as diretrizes da empresa, que não permite gravações de conversas e nem fotos dentro das instalações da fábrica.

O período de entrevista com os executivos ocorreu entre os dias 21 a 28 de fevereiro. O primeiro executivo a ser entrevistado foi o Gerente de Recursos Humanos, responsável pela gestão e relacionamento com os funcionários, a segunda entrevista foi com o Gerente de Qualidade, responsável pela gestão e relacionamento com os fornecedores.

As entrevistas com este grupo foram previamente agendadas, com data e horário estipulado. Antes de iniciar-se a entrevista houve uma apresentação prévia do entrevistador, com o objetivo de esclarecer dúvidas sobre o objetivo da pesquisa, a duração da entrevista e o compromisso de apresentar os resultados obtidos à empresa, no término do trabalho.

O tempo da entrevista, estabelecido entre o mínimo de 20 minutos e o máximo de uma hora, foi cumprido. A entrevista com o Gerente de recursos humanos durou 50 minutos e, a entrevista com Gerente de qualidade durou 34 minutos.

O entrevistador também salientou que as questões que surgissem dúvidas seriam deixadas para o final da entrevista.

Os entrevistados deste grupo solicitaram que antes da realização da entrevista lhes fossem entregue o roteiro de perguntas, pois gostariam de saber exatamente as questões que seriam abordadas, o que contribuiu com maiores informações ao trabalho. 


\subsection{HIPÓTESES}

Todos os métodos utilizados pretendem buscar respostas às hipóteses e objetivos que orientam o trabalho. Como os objetivos já foram descritos na introdução, falta destacar as hipóteses básicas que orientam o estudo:

- A empresa tem adotado alguma estratégia de aproveitamento de seu capital de relacionamento, frente as novas realidades impostas pelo mercado cada vez mais competitivo;

- O relacionamento desta empresa com seus funcionários e fornecedores se enquadram no perfil conhecido de parceria;

- As características de seu relacionamento com fornecedores configuram condições para o estabelecimento de parcerias e alianças estratégicas.

\subsection{ESTUDO DE CASO}

Um fator de extrema relevância na construção de um trabalho está na escolha da empresa a ser estudada, onde se realizará a investigação e posterior análise e conclusões que representem de uma forma mais próxima da realidade o tratamento e as práticas referentes aos temas abordados. Sendo a liberdade de acesso para o pesquisador, em relação as suas fontes, imprescindíveis para o sucesso do estudo.

Primeiramente torna-se importante contextualizar os acontecimentos históricos que motivaram a criação da Fábrica de Motores São Carlos, uma empresa do grupo Volkswagen, para tanto será utilizado como fonte de pesquisa: intranet, internet e material impresso da empresa.

\subsubsection{DADOS SOBRE A CIDADE SÃO CARLOS (SP)}

É importante destacar algumas características da cidade que motivaram a instalação da Volkswagen. São Carlos localiza-se a 230 km da cidade de São Paulo com uma população estimada em 206.958 habitantes. Contém um parque industrial de 600 indústrias que corresponde a 47,4\% dos empregados formais da região. As indústrias 
que se destacam são as de máquinas e equipamentos (11,2\% dos empregos), alimentos e bebidas $(8,3 \%)$, extração de minerais não-metálicos $(5,8 \%)$, indústria de móveis $(5 \%)$, têxtil $(3,5 \%)$ e da construção civil $(2,5 \%)$. Denotando certa especialização desta região nestas indústrias específicas. Entre estas se destacam empresas multinacionais como, Johan Faber, Electrolux, Tecumseh e Volkswagen (TUNDISI, 2003).

A participação relativa do Comércio e dos Serviços no total de empregados mantidos na região é inferior à da indústria. A agropecuária emprega 13,6\% de trabalhadores da região, são destaques a cultura de cana $(4,9 \%)$, as unidades rurais de uso misto $(2,4 \%)$ e a cultura de frutas cítricas $(1,5 \%)$. Particularmente a cultura de frutas cítricas e a criação de aves são atividades que mantém uma participação relativa nos empregos da região (SEBRAE, 2001).

Porém um fato importante e que destaca a cidade de São Carlos em caráter nacional diz respeito as duas universidades públicas nela instalada, a USP (Universidade de São Paulo) e a UFSCar (Universidade Federal de São Carlos). Outro dado importante a ressaltar é que esta cidade tem a maior concentração de doutores por habitantes no Brasil, um para cada 180, o que propicia considerável volume de conhecimento a ser aproveitado pelas empresas instaladas na cidade.

É importante destacar que existe uma preocupação da cidade com o setor de micro e pequenas empresa, que absorve grande parte desta mão de obra. Instituições como o Sebrae (Serviço Brasileiro de apoio a empresa) servem de apoio aos empreendedores, que se utilizam por exemplo do Parqtec (Parque Tecnológico) para encubadorem suas empresas. Outras instituições de pesquisa como a Embrapa (Empresa Brasileira de Pesquisa Agropecuária), que desenvolve pesquisas para o setor agrícola, também contribuem para dissiminação do conhecimento na região.

\subsubsection{HISTÓRIA DA FUNDAÇÃO DA VW EM SÃO CARLOS}

Com a decisão de dissolver a Autolatina (fusão da Volkswagen do Brasil com a Ford do Brasil), a Volkswagen viu-se diante de um dilema, o Gol 1000, modelo de grande participação no mercado que utilizava um motor derivado do antigo Ford CHT 1600cc, estava perdendo terreno para os modelos Mille (Fiat) e Corsa (GM) e poderia deixar de ser fornecido pela Ford. Porém, pelo acordo de separação das empresas (Volkswagen e Ford), este motor ainda seria fornecido pela Ford durante o período de 
um ano, esta situação levou a Volkswagen a buscar uma alternativa no curto prazo. A solução encontrada pela diretoria desta empresa foi instalar uma nova fábrica voltada exclusivamente à produção de motores.

Em uma situação de oportunidade interessante, a Volkswagen conseguiu transformar uma realidade adversa, pois a instalação de uma nova fábrica seria o momento certo para investir em nova tecnologia. Aproveitando-se da oportunidade dos novos investimentos a empresa definiu que esta unidade deveria ser competitiva em termos mundiais e deveria estar integrada ao mundo, produzindo motores de qualidade e a custo compatível viabilizando o fornecimento as outras fábricas da empresa espalhadas em outros países.

Ao se definir o produto a ser fabricado nesta nova empresa, a decisão recaiu sobre a família de motores EA-111, um projeto mundial, originário da Alemanha, e que poderia ser produzido nas versões de $1000 \mathrm{cc}$, 1200cc, $1400 \mathrm{cc}$ e $1600 \mathrm{cc}$, todos destinados ao VW Gol. Destaca-se também uma outra família de motores, o EA-113, que pode ser produzido nas versões de 1600cc, 1800cc, 2000cc e 1800cc Turbo, destinado aos modelos VW Golf e Audi. Porém, num primeiro momento, deveria concentrar-se na linha EA-111.

Iniciaram-se então os esforços no sentido de se construir a nova unidade no mais curto prazo possível. Escolhido o local, empreendeutse a instalação propriamente dita. A inauguração ocorreu em 12 de outubro de 1996. Apesar de algum atraso no cronograma, causado por dificuldades com importação e nacionalização, esta fábrica foi instalada em tempo recorde: apenas 11 meses.

A Fábrica de Motores de São Carlos (Figura 9), possui uma área construída de $35.000 \mathrm{~m}^{2}$, instalada em uma área total de $7.500 .000 \mathrm{~m}^{2}$. Conta hoje com aproximadamente 500 empregados, além de funcionários de terceiros. A unidade já recebeu R \$ 350 milhões em investimentos e possui duas diferentes linhas de produção: EA 111, criada no início das atividades da fábrica, e EA 113, inaugurada em 1998 para atender a demanda da fábrica da VW/Audi no Paraná. 


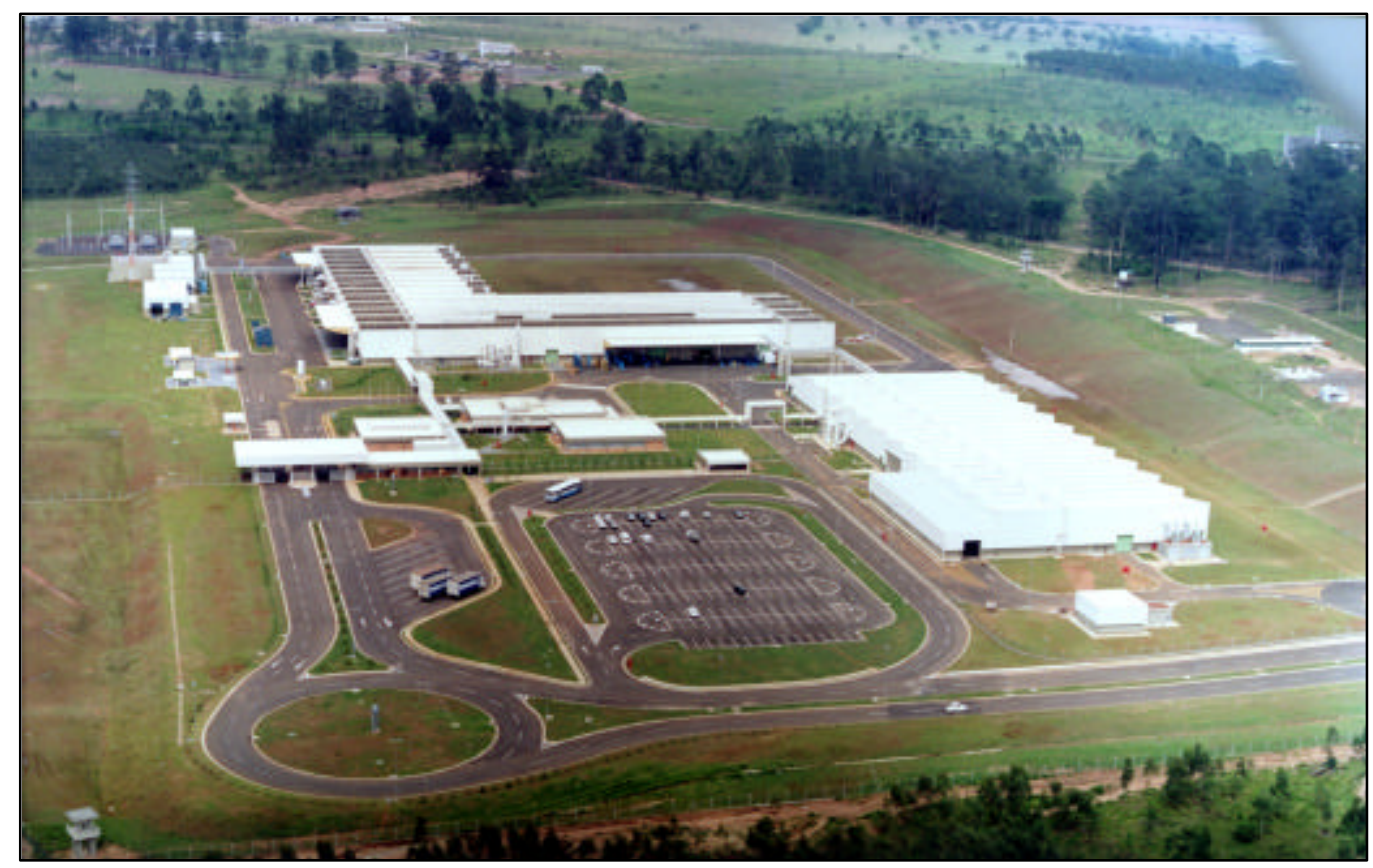

Figura 9 - Fábrica de Motores São Carlos.

Fonte: <http/vwbintranet.imprensa.rp/historia-mundo>

Com uma capacidade instalada de fabricação de 2.850 motores/dia, esta planta produz atualmente 1720 motores por dia. São 15 tipos diferentes de motores, alimentados por combustíveis diversos como gasolina, álcool ou ambos e o diesel, que equipam os modelos Gol, Parati, Saveiro, Fox, Golf, Audi A3, Polo hatch e sedan, sendo consumidos pelas plantas localizadas no estado de São Paulo (São Bernardo do Campo e Taubaté) e Paraná (São José dos Pinhais), além de outros países como Argentina, Espanha e África do Sul. Em abril de 2001 a fábrica atingiu a marca de 1,5 milhões de motores produzidos.

Projetada para produzir com a mesma qualidade das melhores indústrias européias, São Carlos foi a primeira planta do grupo VW, fora da Europa, a conquistar o certificado ambiental ISO 14001, em 1997, e se tornou referência em gestão ambiental para as demais unidades na América do Sul.

A empresa possui também uma ETE - Estação de Tratamento de Efluentes, que trata todo o esgoto que produz e muitas vezes superam os rígidos padrões europeus de controle de emissão de poluentes. Purificação de gases e reciclagem de lixo são outras medidas adotadas com relação à preservação ambiental.

Por ser esta uma empresa socialmente responsável, tem o compromisso com a melhoria contínua para alcançar a compatibilidade entre seus processos, produtos e o 
meio ambiente, assim como a redução da utilização dos recursos naturais visando a preservação do meio e a prevenção dos danos ambientais, através do cumprimento da legislação e demais normas ambientais vigentes, principalmente das que tratam de geração de emissões atmosféricas, uso e descarte de água, manipulação de materiais perigosos e disposição final de resíduos perigosos (VOLKSWAGEN, 2005).

\subsubsection{ESTRUTURA ORGANIZACIONAL DA VW EM SÃO CARLOS}

A estrutura da empresa é simples, o que permite um acesso rápido as informações tanto por parte da gerência como por parte dos funcionários de chão de fábrica. É uma estrutura importante de observar já que permite um contato muito direto com os executivos da empresa, o que praticamente seria impossível em outras plantas da organização. O desenho organizacional (Figura 10) se divide da seguinte forma:

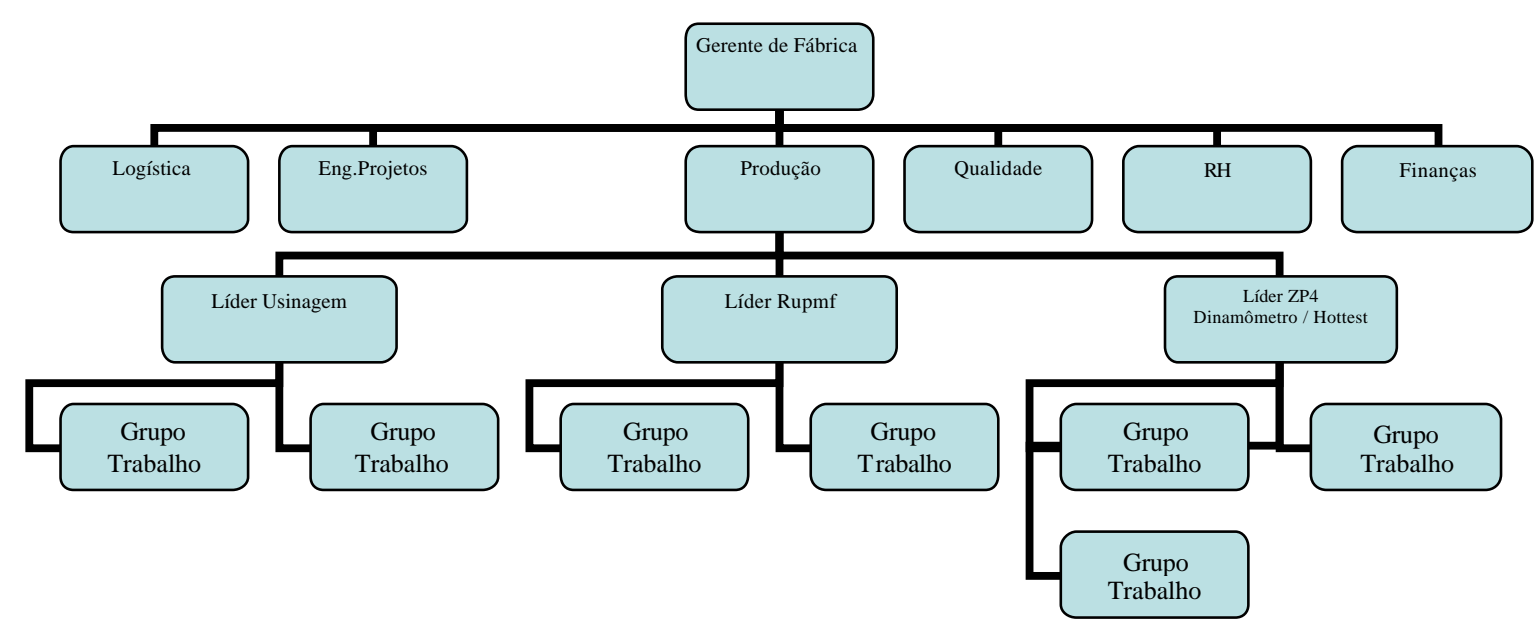

Figura 10: Estrutura Organizacional da Empresa

Fonte: adaptada dosite <http/vwbintranet.imprensa.rp/historia-mundo>

- Gerência: responsável direto por atender as necessidades dos clientes, emitir relatórios da situação da empresa como o número de inventário, quantidade produzida, etc. É importante ressaltar que mesmo se colocando abaixo na estrutura hierárquica, outros setores como qualidade, $\mathrm{RH}$, e finanças, não são subordinados diretos da gerência, possuem um papel de staff, e respondem diretamente para seus superiores em nível nacional;

- RH: responsável pela gestão dos funcionários da empresa, assuntos sobre relações trabalhistas, assistência, controle de horas extras, saúde e segurança no trabalho e administração de pessoal e serviços; 
- Finanças: responsável por todo o controle financeiro da VW São Carlos, como, por exemplo, liberando ou não compras de matérias para manutenção de máquinas (investimentos, administração de custo, custos logísticos, custos qualidade, débitos fornecedores, bugte, forecaste);

- Produção: responsável pelo volume de produção a ser alcançado diária e mensalmente, canalizando todos os recursos disponíveis para isto. Responde diretamente a gerência, controla áreas como manutenção e células de produção;

- Qualidade: responsável por toda a gestão de qualidade dentro da planta, controlando e medindo todos os produtos consumidos ou produzidos (QA peças, QA produto, QA planejamento, QA processos, QA auditoria);

- Engenharia: responsável pela implementação de novos projetos ou alterações nas linhas de produção (processos industriais; novos projetos; planejamento; ferramentas);

- Logística: responde pelo abastecimento da fábrica com componentes que farão parte dos motores produzidos e transportes de produtos acabados às outras plantas do grupo;

- Líder Usinagem: responsável por turno, com objetivo de usinar os blocos para as etapas posteriores, controlando um número pequeno de pessoas e um grande número de medidas e parâmetros;

- Líder RUMPF: responsável por turno, orientando os montadores na entrega dos motores em condições ideais para próxima etapa;

- Líder ZP4: responsável por turno, com objetivo de controlar o acabamento dos motores, testes finais e carregamento dos mesmos.

É importante destacar que além do desenho organizacional da empresa, existem outros desenhos que facilitam a análise desta organização, como o caso do fluxo de produção (Figura 11), que serve como orientador e facilitador na visualização de todo o processo produtivo. Este fluxo se inicia no ponto número $1 \mathrm{com}$ a entrada de blocos fundidos que serão usinados, posteriormente estes passam para o ponto 2, montagem parcial do motor, que encaminha ao ponto 3 , montagem final do motor, a seguir este são levados ao ponto 4 e testados e, por último são conduzidos ao ponto 5, saída destes motores para os clientes. 


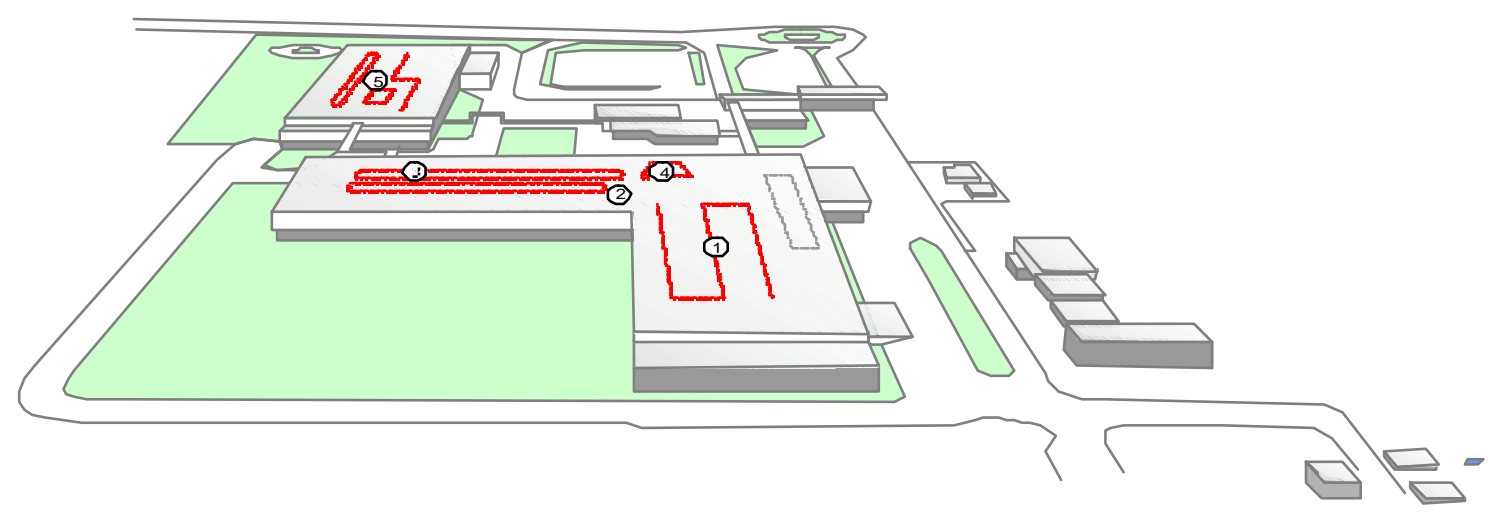

Figura 11: Fluxo de produção da planta São Carlos - motores ZP4 - EA111.

Fonte: <http/vwbintranet.imprensa.rp/historia-mundo>

Primeira etapa: usinagem (1). Após liberação os blocos são encaminhados para o setor de usinagem. Esta linha é formada por máquinas Transfer que executam as operações automaticamente, respeitando todos os quesitos necessários para atender a certificação ISO 14000 (Meio Ambiente), como o transporte de resíduos e aproveitamento dos mesmos.

A capacidade desta linha é de: 1.650 blocos/dia; 20 funcionários por turno; 03 turnos de trabalho; Inha de 250 metros em formato de $S$; tempo de 32 segundos; 24 máquinas; blocos usinados 1.6L Golf/Polo, 1.0L Turbo Gol/Parati, 1.0L Potenciado Gol/Parati, 1.0L Tasse Gol Special.

Segunda etapa: motor parcial (2). Fase intermediária de montagem dos motores da família EA-111 onde são agregados ao bloco todos os componentes internos do motor (virabrequim, pistões, bielas, flanges, etc.). No trecho final de linha o bloco e as peças internas recebem o cárter e o cabeçote. Finalizando, o conjunto, chamado Rumpf Motor ou Motor Parcial, passa pelo teste de estanqueidade estando pronto para seguir para a linha de montagem final de motores (ZP-4). A capacidade diária é de: 1720 motores; volume diário 1720, com 15 tipos de motores diferentes; 30 estações manuais e 25 estações automáticas.

A linha é construída sobre o conceito de células visando organizar e buscar maior eficiência. Trabalha por turno com um eletricista e um mecânico de manutenção, um líder, dois monitores responsáveis pelas suas células e um número pequeno de pessoas, o que torna a comunicação muito rápida e dinâmica. 
Terceira etapa: motor completo ZP4 (3). Nesta linha os motores recebem os periféricos para o acabamento final, tais como cabos de velas, parte elétrica e óleo. Estes produtos são necessários para realização de teste antes da liberação dos mesmos. Capacidade diária: 1720 motores; volume diário 1720; 23 tipos diferentes de motores; 49 estações manuais; 15 estações automáticas. Sua organização é similar a da Rumpf Motor com exceção no número de funcionários que é maior.

Quarta etapa: Hot-Test e Kalt-Test (4). Até o ano de 2002 no momento em que o motor completo saía da linha de montagem (ZP4) este já estava em condições de ser testado, com exceção de alguns entregues em Taubaté, os quais são testados por lotes, em condições especiais.

O teste consistia em "ligar" o motor e cumprir um check-list de tarefas, verificando o comportamento geral do mesmo. Como a partida do motor se dá no momento do teste, este é denominado teste a quente (Hot-Test), e para tratamento dos gases emitidos, a empresa possui equipamentos denominados Lavadores de Gases.

A partir do ano de 2003 praticamente todos os motores passaram a ser testados pelo sistema Kalt-Test, restando ainda pequenos lotes que passam pelo método anterior. Suas vantagens são enormes tanto na segurança dos funcionários como no controle de gases poluentes, já que este não possui queima de combustíveis, isto sem considerar os ganhos com a diminuição do CT (cyclo time) que anteriormente era de 4 minutos e passou para 42 segundos, permitindo assim a instalação destas máquinas dentro do processo produtivo e não separado como anteriormente.

Quinta etapa: remessa (5). Após os testes anteriores prepara-se a carga a ser enviada. Emite-se os documentos necessários, confere física e documentalmente os materiais ou embalagens a serem enviados, efetua o carregamento dos veículos, lacrando-os. As distribuições de produtos para as Plantas são efetuadas conforme Solicitações Diárias (memo), Solicitações Semanais (Release) e Solicitações Conforme Consumo (Kanban).

Com esse processo a Volkswagen, através da planta São Carlos, oferece alguns modelos de motores conforme Figura 12. 


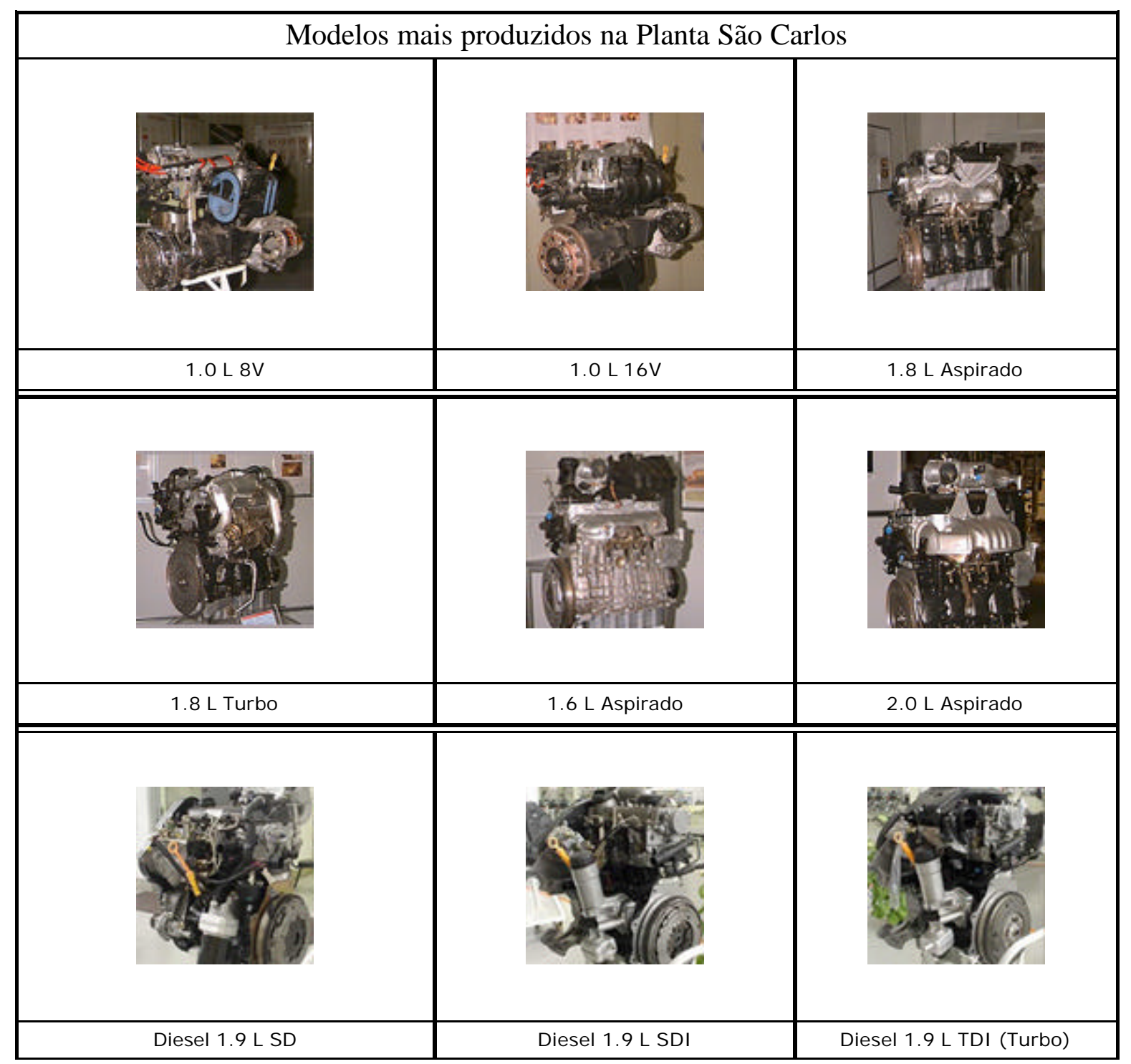

Figura 12: Motores da planta São Carlos.

Fonte: 〈http/vwbintranet.imprensa.rp/historia-mundo>

É importante destacar que em um curto espaço de tempo, a fábrica conseguiu resultados significativos com a redução no ciclo de produção dos motores, redução de custos e ganho de flexibilidade. Tornando-se desta maneira a melhor unidade de produção da marca no mundo. Seus parâmetros de qualidade situam-se acima do mercado, assegurando produtos com aceitação irrestrita em mercados mais exigentes.

O próximo capítulo deste trabalho destina-se a detalhar e discutir os resultados obtidos na pesquisa de campo realizada junta a esta empresa, com a participação de seus funcionários e fornecedores. 


\section{CAPÍTULO 6}

\section{APRESENTAÇÃO, ANÁLISE E DISCUSSÃO DOS DADOS}

Este capítulo destina-se a apresentar e detalhar os resultados encontrados na pesquisa, através dos questionários aplicados aos funcionários e fornecedores da empresa estudada, juntamente com o resultado das entrevistas fornecidas pelos executivos desta empresa. Com o propósito de facilitar as observações referentes as análises, separou-se as questões de acordo com as variáveis estudadas (conhecimento, comprometimento, relacionamento, custos, responsabilidade, informação e qualidade), ressaltando que as questões utilizadas para a construção dos questionários encontram-se nos Apêndices A e B.

\subsection{ANÁLISE DOS DADOS}

A partir das respostas obtidas através dos questionários (Apêndices A e B) complementadas com as informações coletadas nas entrevistas (Apêndice C), podem-se realizar algumas análises a fim de se chegar a conclusões relacionadas aos objetivos desta pesquisa. Destacando que as análises realizadas se baseiam no conjunto de todas as variáveis encontradas durante a revisão bibliográfica, buscando investigar como a empresa visualiza e gerencia seu capital de relacionamento.

Após o término da etapa de coleta de dados, iniciou-se a tabulação destes com a realização de uma análise estatística das respostas referentes aos questionários, procurando identificar comportamentos e tendências. Para tanto foram utilizados os softwares Microsoft Excel 2000, SAS System 1999-2001 e Minitab.

Para a análise estatística foram consideradas as respostas das questões 1 a 19 do questionário aplicado aos funcionários (Apêndice A) e as questões 1 a 20 do questionário aplicado aos fornecedores (Apêndice B). 
Antes de aprofundar-se nos resultados obtidos é importante apresentar e explicar os critérios utilizados para as análises dos dados estatísticos, uma vez que a escala utilizada foi de 1 à 7 , onde estabeleceu-se o seguinte intervalo de valores para determinação do nível de concordância dos pesquisados quanto aos questionamentos: intervalo de valor inferior a 4 equivale ao nível de baixa concordância; intervalo de valor igual a 4 equivale ao nível de média concordância; intervalo de valor superior a 4 equivale ao nível de alta concordância.

A seguir serão detalhados e discutidos os resultados separando-os por objetos de pesquisas (funcionários, fornecedores e executivos). É importante destacar que para a análise dos dados obtidos utilizourse o teste Binomial e a análise de correspondência, que serão explicados mais profundamente nas suas respectivas análises.

\subsection{GRUPO FUNCIONÁRIOS}

Este grupo compreende as questões relacionadas à parte I do questionário (Apêndice A), que busca verificar qual a opinião dos funcionários da empresa, que trabalham em diferentes turnos (primeiro turno, segundo turno, terceiro turno e mensalistas), em relação as variáveis apresentadas na pesquisa (conhecimento, comprometimento, relacionamento, custos, responsabilidade, informação e qualidade) que constituem os elementos formadores do capital de relacionamento. A Tabela 5, a seguir, apresenta os resultados referentes ao primeiro turno deste grupo.

Tabela 5 - Porcentagem de cada questão para o primeiro turno

\begin{tabular}{|c|c|c|c|c|}
\hline Questão & Variável & \%Discordância & \% Concordância & \% Mais ou Menos \\
\hline $\mathbf{1}$ & conhecimento & 44,4 & 33,3 & 22,2 \\
\hline $\mathbf{2}$ & conhecimento & 50,0 & 44,4 & 5,6 \\
\hline $\mathbf{3}$ & comprometimento & 5,6 & 72,2 & 22,2 \\
\hline $\mathbf{4}$ & comprometimento & 23,5 & 76,5 & 0 \\
\hline $\mathbf{5}$ & relacionamento & 16,7 & 55,6 & 27,8 \\
\hline $\mathbf{6}$ & custos & 66,7 & 22,2 & 11,1 \\
\hline $\mathbf{7}$ & custos & 33,3 & 50,0 & 16,7 \\
\hline $\mathbf{8}$ & responsabilidade & 11,1 & 72,2 & 16,7 \\
\hline $\mathbf{9}$ & responsabilidade & 44,4 & 50,0 & 5,6 \\
\hline $\mathbf{1 0}$ & responsabilidade & 22,2 & 72,2 & 5,6 \\
\hline $\mathbf{1 1}$ & informação & 16,7 & 66,7 & 16,7 \\
\hline $\mathbf{1 2}$ & informação & 50,0 & 27,8 & 22,2 \\
\hline
\end{tabular}


Tabela 5 - Porcentagem de cada questão para o primeiro turno

\begin{tabular}{|c|c|c|c|c|}
\hline Questão & Variável & \%Discordância & \% Concordância & \%Mais ou Menos \\
\hline $\mathbf{1 3}$ & informação & 22,2 & 38,9 & 38,9 \\
\hline $\mathbf{1 4}$ & relacionamento & 0 & 94,4 & 5,6 \\
\hline $\mathbf{1 5}$ & qualidade & 0 & 94,1 & 5,9 \\
\hline $\mathbf{1 6}$ & qualidade & 17,6 & 47,1 & 35,3 \\
\hline $\mathbf{1 7}$ & relacionamento & 0 & 94,4 & 5,6 \\
\hline $\mathbf{1 8}$ & relacionamento & 38,9 & 27,8 & 33,3 \\
\hline $\mathbf{1 9}$ & relacionamento & 0 & 100 & 0 \\
\hline
\end{tabular}

Com base nos dados obtidos através das respostas fornecidas pelos funcionários do primeiro turno, pôde-se chegar a seguintes observações.

A maioria dos entrevistados concorda com as observações levantadas nas questões, porém é importante destacar que quase um terço dos entrevistados discordam. Esta situação não chega a ser significativa, mas elevam as preocupações, ou seja, podese considerar um estado de atenção para este grupo caso outros fatores venham a afetar outras variáveis de maneira negativa.

Para melhor assimilação dos dados, a seguir será discutida cada questão em que o percentual de discordância foi superior:

- Na questão do conhecimento (perguntas 1 e 2), os pesquisados discordam que a empresa estimule e promova a criação e compartilhamento do conhecimento com seus funcionários e fornecedores, e ainda discordam da eficiência das ferramentas utilizadas pela empresa.

É importante destacar que a gestão do conhecimento se transformou nos últimos anos em um dos principais objetos de estudo das áreas acadêmicas e industriais, principalmente pelo lucro proporcionado por este, somado também a dificuldade em se gerenciar este importante ativo intangível. Por isso esta situação acentua ainda mais os resultados obtidos neste grupo, já que houve discordância dos questionamentos abordados no trabalho. É aconselhável a empresa fazer uma reflexão de seu gerenciamento sobre este ativo, juntamente com as ferramentas utilizadas para isso.

- Na questão relacionada à variável custo (pergunta 6), os pesquisados discordam dos treinamentos fornecidos pela empresa para a fabricação de novos produtos.

As reduções de custos, sejam eles fixos ou variáveis, é uma busca constante na maioria das organizações e esta situação também aparece no presente estudo, onde a 
empresa utiliza-se de várias técnicas e ferramentas com este objetivo. O fato deste grupo discordar dos treinamentos fornecidos requer maior atenção, pois o treinamento não adequado pode acarretar custos enormes no futuro, custos estes que podem até afetar a própria imagem da empresa no mercado.

- $\mathrm{Na}$ questão relacionada à variável informação (pergunta 12), os entrevistados também discordam que a empresa comunique de forma clara as expectativas sobre eles.

A falta de comunicação ou a falha desta pode acarretar problemas, principalmente no que diz respeito à quebra de expectativas que é o primeiro passo para se desmotivar o funcionário e, esta situação pode levar a perda de bons profissionais e até mesmo possíveis talentos.

- Na questão relacionada à variável relacionamento (pergunta 18), os funcionários também discordam que a empresa reconheça os serviços prestados por estes.

A falta de reconhecimento é outro sério problema a ser gerenciado, pois este também é um dos principais caminhos que levam a desmotivação dos funcionários. Este reconhecimento pode vir através de gestos, atitudes e não apenas do reconhecimento monetário. Destaca-se que mesmo a empresa possuindo várias ferramentas para reconhecer a boa atuação de seus funcionários, ao que parece neste grupo isto não surtiu bons resultados.

Como já mencionado anteriormente a maioria das pessoas deste grupo encontra-se em concordância com as questões abordadas no trabalho, porém procurout se dar maior ênfase nos aspectos em discordância, com o propósito de buscar evidenciar possíveis problemas para a empresa em questão.

A seguir, a Tabela 6 apresenta os resultados referentes ao segundo turno do grupo funcionários.

Tabela 6 - Porcentagem de cada questão para o segundo turno

\begin{tabular}{|c|c|c|c|c|}
\hline Questão & Variável & \%Discordância & \%Concordância & \% Mais ou Menos \\
\hline $\mathbf{1}$ & conhecimento & 35,7 & 50,0 & 14,3 \\
\hline $\mathbf{2}$ & conhecimento & 21,4 & 71,4 & 7,1 \\
\hline $\mathbf{3}$ & comprometimento & 0 & 85,7 & 14,3 \\
\hline $\mathbf{4}$ & comprometimento & 7,1 & 92,9 & 0 \\
\hline $\mathbf{5}$ & relacionamento & 14,3 & 85,7 & 0 \\
\hline $\mathbf{6}$ & custos & 42,9 & 42,9 & 14,3 \\
\hline $\mathbf{7}$ & custos & 28,6 & 57,1 & 14,3 \\
\hline
\end{tabular}


Tabela 6 - Porcentagem de cada questão para o segundo turno

\begin{tabular}{|c|c|c|c|c|}
\hline Questão & Variável & \%Discordância & \%Concordância & \% Mais ou Menos \\
\hline $\mathbf{8}$ & responsabilidade & 0 & 100 & 0 \\
\hline $\mathbf{9}$ & responsabilidade & 14,3 & 64,3 & 21,4 \\
\hline $\mathbf{1 0}$ & responsabilidade & 14,3 & 85,7 & 0 \\
\hline $\mathbf{1 1}$ & informação & 21,4 & 50,0 & 28,6 \\
\hline $\mathbf{1 2}$ & informação & 50,0 & 35,7 & 14,3 \\
\hline $\mathbf{1 3}$ & informação & 14,3 & 64,3 & 0 \\
\hline $\mathbf{1 4}$ & relacionamento & 0 & 100 & 0 \\
\hline $\mathbf{1 5}$ & qualidade & 7,1 & 92,9 & 7,7 \\
\hline $\mathbf{1 6}$ & qualidade & 0 & 92,3 & 7,1 \\
\hline $\mathbf{1 7}$ & relacionamento & 7,1 & 85,7 & 7,1 \\
\hline $\mathbf{1 8}$ & relacionamento & 50,0 & 42,9 & 0 \\
\hline $\mathbf{1 9}$ & relacionamento & 7,1 & 92,9 & \\
\hline
\end{tabular}

A maioria dos entrevistados deste grupo concorda com as observações levantadas nas questões. Este é um dado importante, pois pode indicar um bom relacionamento deste grupo com a empresa. Destaca-se que somente em duas questões houve discordância.

- Na questão relacionada à variável informação (pergunta 12), os entrevistados discordam que a empresa comunique de forma clara as expectativas sobre eles.

- Na questão relacionada a reconhecimento (pergunta 18), os funcionários discordam que a empresa reconheça os serviços prestados por estes.

E importante destacar que estas duas questões também foram mencionadas no grupo anterior, os funcionários do primeiro turno. Esta repetição pode significar um alerta maior, pois o fato de surgirem às mesmas opiniões em grupos heterogêneos sugere que a empresa reveja seus métodos de trabalhar essas variáveis.

Outro aspecto importante a destacar diz respeito à questão 6 , relativa a custos, onde o percentual de concordância e discordância foram exatamente os mesmos.

A seguir apresentam-se, através da Tabela 7, os resultados obtidos com os funcionários do terceiro turno.

Tabela 7 - Porcentagem de cada questão para o terceiro turno

\begin{tabular}{|c|c|c|c|c|}
\hline Questão & Variável & \%Discordância & \%Concordância & \%Mais ou Menos \\
\hline $\mathbf{1}$ & conhecimento & 28,6 & 57,1 & 14,3 \\
\hline $\mathbf{2}$ & conhecimento & 28,6 & 28,6 & 42,9 \\
\hline $\mathbf{3}$ & comprometimento & 14,3 & 57,1 & 28,6 \\
\hline $\mathbf{4}$ & comprometimento & 28,6 & 71,4 & 0 \\
\hline $\mathbf{5}$ & relacionamento & 28,6 & 71,4 & 0 \\
\hline
\end{tabular}


Tabela 7 - Porcentagem de cada questão para o terceiro turno

\begin{tabular}{|c|c|c|c|c|}
\hline Questão & Variável & \%Discordância & \%Concordância & \% Mais ou Menos \\
\hline $\mathbf{6}$ & custos & 71,4 & 28,6 & 0 \\
\hline $\mathbf{7}$ & custos & 28,6 & 57,1 & 14,3 \\
\hline $\mathbf{8}$ & responsabilidade & 28,6 & 57,1 & 14,3 \\
\hline $\mathbf{9}$ & responsabilidade & 42,9 & 28,6 & 28,6 \\
\hline $\mathbf{1 0}$ & responsabilidade & 0 & 85,7 & 14,3 \\
\hline $\mathbf{1 1}$ & informação & 14,3 & 71,4 & 14,3 \\
\hline $\mathbf{1 2}$ & informação & 28,6 & 57,1 & 14,3 \\
\hline $\mathbf{1 3}$ & informação & 42,9 & 42,9 & 0 \\
\hline $\mathbf{1 4}$ & relacionamento & 0 & 100 & 0 \\
\hline $\mathbf{1 5}$ & qualidade & 0 & 100 & 28,6 \\
\hline $\mathbf{1 6}$ & qualidade & 0 & 71,4 & 14,3 \\
\hline $\mathbf{1 7}$ & relacionamento & 0 & 85,7 & 0 \\
\hline $\mathbf{1 8}$ & relacionamento & 57,1 & 42,9 & 0 \\
\hline $\mathbf{1 9}$ & relacionamento & 0 & 100 & \\
\hline
\end{tabular}

Os dados obtidos nas respostas fornecidas pelos funcionários do terceiro turno também demonstraram pouca divergência em relação às questões abordadas na pesquisa, pois somente em dois itens houve discordância, especificamente na pergunta 6 que diz respeito a variável custo, e na pergunta 18 referente à variável relacionamento. Ressaltando que estas discordâncias também já foram detectadas no primeiro turno.

É importante destacar que em outras duas questões, a questão 2 relacionada à variável conhecimento e a 13 relacionada à informação, a quantidade de pessoas que concordam e que discordam foram exatamente a mesma. Este é um dado importante a se considerar, pois caso ocorra alteração para o nível de discordância em alguma destas variáveis, poderá levar o grupo a um possível estado de atenção, pelo fato de se possuir neste caso um número significativo de discordâncias.

A Tabela 8, a seguir, apresenta os resultados referentes ao grupo mensalistas.

Tabela 8 - Porcentagem de cada questão para os mensalistas

\begin{tabular}{|c|c|c|c|c|}
\hline Questão & Variável & \%Discordância & \%Concordância & \% Mais ou Menos \\
\hline $\mathbf{1}$ & conhecimento & 80,0 & 0 & 20,0 \\
\hline $\mathbf{2}$ & conhecimento & 100 & 0 & 0 \\
\hline $\mathbf{3}$ & comprometimento & 0 & 80,0 & 20,0 \\
\hline $\mathbf{4}$ & comprometimento & 20,0 & 80,0 & 0 \\
\hline $\mathbf{5}$ & relacionamento & 20,0 & 60,0 & 20,0 \\
\hline $\mathbf{6}$ & custos & 40,0 & 20,0 & 40,0 \\
\hline $\mathbf{7}$ & custos & 60,0 & 40,0 & 0 \\
\hline $\mathbf{8}$ & responsabilidade & 20,0 & 80,0 & 0 \\
\hline $\mathbf{9}$ & responsabilidade & 60,0 & 20,0 & 20,0 \\
\hline $\mathbf{1 0}$ & responsabilidade & 0 & 100 & 0 \\
\hline $\mathbf{1 1}$ & informação & 40,0 & 40,0 & 20,0 \\
\hline
\end{tabular}


Tabela 8 - Porcentagem de cada questão para os mensalistas

\begin{tabular}{|c|c|c|c|c|}
\hline Questão & Variável & \%Discordância & \%Concordância & \%Mais ou Menos \\
\hline $\mathbf{1 2}$ & informação & 80,0 & 20,0 & 0 \\
\hline $\mathbf{1 3}$ & informação & 60,0 & 0 & 40,0 \\
\hline $\mathbf{1 4}$ & relacionamento & 0 & 80,0 & 20,0 \\
\hline $\mathbf{1 5}$ & qualidade & 0 & 100 & 0 \\
\hline $\mathbf{1 6}$ & qualidade & 20,0 & 80,0 & 0 \\
\hline $\mathbf{1 7}$ & relacionamento & 20,0 & 20,0 & 60,0 \\
\hline $\mathbf{1 8}$ & relacionamento & 20,0 & 40,0 & 40,0 \\
\hline $\mathbf{1 9}$ & relacionamento & 0 & 100 & 0 \\
\hline
\end{tabular}

De todos os grupos pesquisados individualmente este é o que se destaca em estado de maior atenção, devido principalmente ao expressivo número de discordância nas questões elaboradas na pesquisa. Esta situação pode sugerir à empresa a importância de se observar a condução do seu relacionamento com este grupo.

A seguir será discutida cada questão em que houve discordância, exceto as que já foram detectadas nos grupos anteriores:

- Na questão do conhecimento (perguntas 1 e 2), os pesquisados discordam que a empresa estimule e promova a criação e compartilhamento do conhecimento com seus funcionários e fornecedores, e ainda discordam da eficiência das ferramentas utilizadas pela empresa.

- Na questão relacionada a variável custo (perguntas 6 e 7), os pesquisados discordam dos treinamentos fornecidos pela empresa para a fabricação de novos produtos e da eficiência da política de redução de custos.

Destacando que este grupo está ligado às áreas de qualidade, logística e engenharia, ou seja, pessoas que possuem contato próximo com clientes e processos, daí a importância de suas opiniões com relação a variável custo.

Um aspecto importante a ser mencionar é que todo o grupo discorda da eficiência das ferramentas utilizadas pela empresa na gestão do conhecimento (questão 2), este dado é pouco comum, pois foi o único com conotação negativa a ter um valor tão expressivo e, este fato chama a atenção para análises mais profundas.

- $\mathrm{Na}$ questão relacionada a variável responsabilidade (pergunta 9), os entrevistados discordam do compartilhamento das responsabilidade em eventuais falhas no processo.

Avaliando esta questão, é possível que a empresa não venha cobrando efetivamente os responsáveis em eventuais falhas no processo, ocasionando assim certo 
desconforto entre os entrevistados deste grupo, e ainda que a informação neste sentido possa estar sendo prejudicada por outros fatores a serem estudados mais profundamente.

- $\mathrm{Na}$ questão relacionada a variável informação (perguntas 12 e 13), os pesquisados discordam da eficiência das ferramentas utilizadas pela empresa em comunicar seus funcionários sobre suas expectativas.

Este resultado pode trazer problemas futuros à empresa, pois a falta de expectativas é um fator motivacional significativo.

Destaca-se que neste grupo existe um número considerável de discordância, pois também em outras duas questões, a questão 11 relacionada a variável informação e a 17 relacionada a variável relacionamento, o percentual de pessoas que concordaram e discordaram foram os mesmos.

A seguir, a Tabela 9 apresenta de forma conjunta os resultados obtidos junto a todos os funcionários entrevistados (primeiro, segundo e terceiro turno e mensalistas).

Tabela 9 - Porcentagem de cada questão no total de funcionários respondentes

\begin{tabular}{|c|c|c|c|c|}
\hline Questão & Variável & \%Discordância & \% Concordância & \% Mais ou Menos \\
\hline $\mathbf{1}$ & conhecimento & 43,2 & 38,6 & 18,2 \\
\hline $\mathbf{2}$ & conhecimento & 43,2 & 45,5 & 11,4 \\
\hline $\mathbf{3}$ & comprometimento & 04,5 & 75,0 & 20,5 \\
\hline $\mathbf{4}$ & comprometimento & 18,6 & 81,4 & 0 \\
\hline $\mathbf{5}$ & relacionamento & 18,2 & 68,2 & 13,6 \\
\hline $\mathbf{6}$ & custos & 56,8 & 29,5 & 13,6 \\
\hline $\mathbf{7}$ & custos & 34,1 & 52,3 & 13,6 \\
\hline $\mathbf{8}$ & responsabilidade & 11,4 & 79,5 & 9,1 \\
\hline $\mathbf{9}$ & responsabilidade & 36,4 & 47,7 & 15,9 \\
\hline $\mathbf{1 0}$ & responsabilidade & 13,6 & 81,8 & 4,5 \\
\hline $\mathbf{1 1}$ & informação & 20,5 & 59,1 & 20,5 \\
\hline $\mathbf{1 2}$ & informação & 50,0 & 34,1 & 15,9 \\
\hline $\mathbf{1 3}$ & informação & 27,3 & 43,2 & 29,5 \\
\hline $\mathbf{1 4}$ & relacionamento & 0 & 95,5 & 4,5 \\
\hline $\mathbf{1 5}$ & qualidade & 2,3 & 95,3 & 2,3 \\
\hline $\mathbf{1 6}$ & qualidade & 9,5 & 69,0 & 21,4 \\
\hline $\mathbf{1 7}$ & relacionamento & 45 & 81,8 & 13,6 \\
\hline $\mathbf{1 8}$ & relacionamento & 43,2 & 36,4 & 20,5 \\
\hline $\mathbf{1 9}$ & relacionamento & 2,3 & 97,7 & 0 \\
\hline & & & & \\
\hline
\end{tabular}

Ao analisarem-se os grupos conjuntamente, os dados obtidos nas respostas demonstram, de modo geral, pouca discordância, pois apenas em quatro itens foram detectados discordâncias dos questionamentos elaborados na pesquisa, especificamente 
na questão 1 que diz respeito a variável conhecimento, na 6 referente a variável custos, na 12 referente a variável informação e na 18 referente a variável relacionamento.

No subitem a seguir, apresenta-se os resultados encontrados, através do Teste Binomial, um dos métodos de análise utilizado no trabalho.

\subsubsection{TESTE BINOMIAL}

O Teste Binomial é usado para fazer inferências de diferenças entre duas populações baseadas em dados de duas amostras aleatórias. Ele fornece o p-value que informa se a proporção amostral de diferenças é significativas, isto é se $\mathrm{H}_{0}$ for a hipótese verdadeira.

No presente trabalho o Teste Binomial será utilizado como método de análise de proporção que compara as visões e opiniões entre os funcionários de turnos diferentes a respeito das mesmas questões.

\section{A) Comparação entre o primeiro turno (t1) e segundo turno (t2)}

\section{Hipótese Científica:}

$\mathbf{H}_{\mathbf{0}}$ : Proporções de "discordância", "concordância" e "indiferente" são iguais para funcionários do primeiro e do segundo turno.

$\mathbf{H}_{1}$ : Proporções de "discordância", "concordância" e "indiferente" são diferentes para funcionários do primeiro e do segundo turno.

\section{Hipótese Estatística:}

$$
\mathbf{H}_{0}:\left(\begin{array}{l}
P 1_{t 1} \\
P 2_{t 1} \\
P 3_{t 1}
\end{array}\right)=\left(\begin{array}{l}
P 1_{t 2} \\
P 2_{t 2} \\
P 3_{t 2}
\end{array}\right) \quad \mathbf{H}_{1}:\left(\begin{array}{l}
P 1_{t 1} \\
P 2_{t 1} \\
P 3_{t 1}
\end{array}\right) \neq\left(\begin{array}{l}
P 1_{t 2} \\
P 2_{t 2} \\
P 3_{t 2}
\end{array}\right)
$$

Tal que $P 1$ é a proporção de funcionários que discordam, $P 2$ é a proporção de funcionários indiferentes e $P 3$ é a proporção de funcionários que concordam.

Antes de se descrever os resultados obtidos, cabe uma explicação mais detalhada das tabelas que serão apresentadas, onde o resultado final pode indicar duas 
situações, a primeira de aceito que neste caso representa que os funcionários dos dois turnos possuem a mesma opinião sobre a questão analisada, e a segunda de rejeito neste caso indicando a não concordância dos turnos. A Tabela 10, abaixo, apresenta a comparação entre o primeiro e segundo turno do grupo funcionários.

Tabela 10 - Comparação: primeiro e segundo turno

\begin{tabular}{|c|c|c|c|c|c|}
\hline Questão & Variável & p-valor P1 & p-valor P2 & p-valor P3 & Resultado \\
\hline $\mathbf{1}$ & conhecimento & 61,8 & 56,8 & 34,1 & aceito \\
\hline $\mathbf{2}$ & conhecimento & 9,8 & 85,4 & 12,7 & aceito \\
\hline $\mathbf{3}$ & comprometimento & 3,7 & 56,8 & 3,6 & aceito \\
\hline $\mathbf{4}$ & comprometimento & 21,7 & $*$ & 21,7 & aceito \\
\hline $\mathbf{5}$ & relacionamento & 85,4 & 3,2 & 6,8 & rejeito \\
\hline $\mathbf{6}$ & custos & 17,8 & 78,8 & 21,2 & aceito \\
\hline $\mathbf{7}$ & custos & 77,3 & 85,4 & 68,8 & aceito \\
\hline $\mathbf{8}$ & responsabilidade & 19,8 & 10,9 & 3,2 & rejeito \\
\hline $\mathbf{9}$ & responsabilidade & 6,8 & 17,8 & 41,9 & aceito \\
\hline $\mathbf{1 0}$ & responsabilidade & 56,8 & 3,7 & 3,6 & aceito \\
\hline $\mathbf{1 1}$ & informação & 73,2 & 41,9 & 34,1 & aceito \\
\hline $\mathbf{1 2}$ & informação & 1 & 56,8 & 63,1 & aceito \\
\hline $\mathbf{1 3}$ & informação & 56,8 & 2,9 & 15,4 & aceito \\
\hline $\mathbf{1 4}$ & relacionamento & $*$ & 3,7 & 3,7 & aceito \\
\hline $\mathbf{1 5}$ & qualidade & 26,3 & 35,6 & 88,7 & aceito \\
\hline $\mathbf{1 6}$ & qualidade & 1,1 & 7,7 & 0,9 & rejeito \\
\hline $\mathbf{1 7}$ & relacionamento & 24,9 & 85,4 & 40,1 & aceito \\
\hline $\mathbf{1 8}$ & relacionamento & 5,3 & 7,5 & 37,3 & aceito \\
\hline $\mathbf{1 9}$ & relacionamento & 24,9 & $*$ & 24,9 & aceito \\
\hline
\end{tabular}

* $\mathrm{O}$ asterisco representa que as respostas dos entrevistados foram exatamente as mesmas

$\mathrm{Na}$ comparação entre o primeiro e segundo turno pode-se considerar os resultados satisfatórios, pois houve discordância em apenas três questões, especificamente nas questões 5,8 e 16 .

Com relação a questão 5 houve discordância entre os grupos a respeito da satisfação destes sobre o relacionamento com os outros setores da empresa. Destaca-se que a empresa dispensa o mesmo tipo de relacionamento à todos os departamentos, o que deve ser mais bem analisado, já que se pressupõe que um tratamento igualitário evita possíveis conflitos. Para a manutenção de um bom clima organizacional seria interessante buscar mecanismo que levem em consideração os diferentes perfis dos turnos, juntamente com um sistema mais eficiente de comunicação entre estes.

$\mathrm{Na}$ questão 8 houve discordância entre os grupos sobre a preocupação da empresa em relação a segurança de seus funcionários. Este é um fato preocupante, pois 
imagina-se que a empresa forneça todos os recursos disponíveis a estes de uma maneira eficiente, proporcionando assim melhores condições emocionais de trabalho. Porém, cabe ressaltar que os executivos da empresa, em suas respectivas entrevistas, destacaram fortemente sua preocupação neste aspecto.

E por último, a questão 16 em que houve discordância entre os grupos com relação a melhora dos indicadores de qualidade nos últimos anos. É necessário analisar as informações e de que forma elas chegam aos funcionários, pois teoricamente deveriam ser as mesmas. Isto não deve estar ocorrendo, uma vez que os indicadores não são flexíveis ou meramente interpretativos e sim dados exatos que fazem parte do processo de tomada de decisões da empresa.

Destaca-se que na comparação entre o primeiro e segundo turno os resultados são pouco expressivos, porém significativos, pois as questões em que houve discordância representam algumas variáveis importantes para a gestão do relacionamento.

Outro aspecto importante diz respeito ao perfil diferente dos turnos comparados, onde os funcionários do primeiro turno são em sua maioria profissionais com tempo maior de empresa, situação oposta no segundo turno.

\section{B) Comparação entre o primeiro turno (t1) e terceiro turno (t3)}

\section{Hipótese Científica:}

$\mathbf{H}_{\mathbf{0}}$ : Proporções de "discordância", "concordância" e "indiferente" são iguais para funcionários do primeiro e do terceiro turno.

$\mathbf{H}_{1}$ : Proporções de "discordância", "concordância" e "indiferente" são diferentes para funcionários do primeiro e do terceiro turno.

\section{Hipótese Estatística:}

$$
\mathbf{H}_{\mathbf{0}}:\left(\begin{array}{l}
P 1_{t 1} \\
P 2_{t 1} \\
P 3_{t 1}
\end{array}\right)=\left(\begin{array}{l}
P 1_{t 3} \\
P 2_{t 3} \\
P 3_{t 3}
\end{array}\right) \quad \mathbf{H}_{\mathbf{1}}:\left(\begin{array}{l}
P 1_{t 1} \\
P 2_{t 1} \\
P 3_{t 1}
\end{array}\right) \neq\left(\begin{array}{l}
P 1_{t 3} \\
P 2_{t 3} \\
P 3_{t 3}
\end{array}\right)
$$


Tal que $P 1$ é a proporção de funcionários que discordam, $P 2$ é a proporção de funcionários indiferentes e $P 3$ é a proporção de funcionários que concordam.

A Tabela 11, abaixo, apresenta a comparação entre o primeiro e terceiro turno.

Tabela 11 - Comparação: primeiro e terceiro turno

\begin{tabular}{|c|c|c|c|c|c|}
\hline Questão & Variável & p-valor P1 & p-valor P2 & p-valor P3 & Resultado \\
\hline $\mathbf{1}$ & conhecimento & 46,7 & 65,6 & 27,5 & aceito \\
\hline $\mathbf{2}$ & conhecimento & 33,2 & 2,2 & 46,7 & rejeito \\
\hline $\mathbf{3}$ & comprometimento & 47,0 & 73,9 & 46,8 & aceito \\
\hline $\mathbf{4}$ & comprometimento & 79,5 & $*$ & 96,8 & aceito \\
\hline $\mathbf{5}$ & relacionamento & 50,4 & 11,9 & 79,5 & aceito \\
\hline $\mathbf{6}$ & custos & 81,9 & 35,8 & 73,9 & aceito \\
\hline $\mathbf{7}$ & custos & 81,9 & 88,4 & 74,8 & aceito \\
\hline $\mathbf{8}$ & responsabilidade & 28,5 & 88,4 & 46,8 & aceito \\
\hline $\mathbf{9}$ & responsabilidade & 94,3 & 11,2 & 33,2 & aceito \\
\hline $\mathbf{1 0}$ & responsabilidade & 17,4 & 47,0 & 47,8 & aceito \\
\hline $\mathbf{1 1}$ & informação & 0,9 & 88,4 & 81,9 & rejeito \\
\hline $\mathbf{1 2}$ & informação & 33,2 & 65,6 & 17,0 & aceito \\
\hline $\mathbf{1 3}$ & informação & 30,2 & 23,6 & 85,6 & aceito \\
\hline $\mathbf{1 4}$ & relacionamento & $*$ & 52,4 & 52,4 & aceito \\
\hline $\mathbf{1 5}$ & qualidade & $*$ & 51,2 & 51,2 & aceito \\
\hline $\mathbf{1 6}$ & qualidade & 23,5 & 75,1 & 27,6 & aceito \\
\hline $\mathbf{1 7}$ & relacionamento & $*$ & 47,0 & 47,0 & aceito \\
\hline $\mathbf{1 8}$ & relacionamento & 40,9 & 8,0 & 46,8 & aceito \\
\hline $\mathbf{1 9}$ & relacionamento & $*$ & $*$ & $*$ & aceito \\
\hline $\mathbf{0}$ & raproito & & & \\
\hline
\end{tabular}

* $\mathrm{O}$ asterisco representa que as respostas dos entrevistados foram exatamente as mesmas

Na comparação entre o primeiro e terceiro turno pode-se considerar também os resultados satisfatórios, pois houve discordância em apenas duas questões. Os resultados foram diferentes especificamente nas questões 2 e 11 .

Com relação a questão 2 , referente a variável conhecimento, os pesquisados discordam entre si que a empresa utilize de ferramentas eficientes para facilitar o processo de geração e disseminação do conhecimento dentro da mesma.

$\mathrm{Na}$ questão 11, referente a variável informação, os pesquisados discordam entre si da eficiência da empresa em comunicar as estratégias e resultados à eles.

Vale observar a qualidade e de que forma as informação são transmitidas para estes grupos, pois os funcionários do terceiro turno podem estar em desvantagem pelo fato de seu horário de trabalho ser após o final do expediente dos mensalistas e executivos da empresa, diferente dos outros turnos comparados. Esta situação pode estar 
gerando uma falta de fluxo eficiente de informações podendo ser o motivo para a diferença de opiniões.

Os resultados positivos nesta comparação são expressivos, porém é extremamente importante ressaltar as discordâncias com o propósito de evidenciar à organização possíveis problemas de gestão no futuro.

\section{C) Comparação entre o primeiro turno (t1) e mensalista $(M)$}

\section{Hipótese Científica:}

$\mathbf{H}_{\mathbf{0}}$ : Proporções de "discordância", "concordância" e "indiferente" são iguais para funcionários do primeiro turno e mensalista.

$\mathbf{H}_{1}$ : Proporções de "discordância", "concordância" e "indiferente" são diferentes para funcionários do primeiro turno e mensalista.

\section{Hipótese Estatística:}

$$
\mathbf{H}_{\mathbf{0}}:\left(\begin{array}{l}
P 1_{t 1} \\
P 2_{t 1} \\
P 3_{t 1}
\end{array}\right)=\left(\begin{array}{l}
P 1_{M} \\
P 2_{M} \\
P 3_{M}
\end{array}\right) \quad \mathbf{H}_{\mathbf{1}}:\left(\begin{array}{l}
P 1_{t 1} \\
P 2_{t 1} \\
P 3_{t 1}
\end{array}\right) \neq\left(\begin{array}{l}
P 1_{M} \\
P 2_{M} \\
P 3_{M}
\end{array}\right)
$$

Tal que $P 1$ é a proporção de funcionários que discordam, $P 2$ é a proporção de funcionários indiferentes e $P 3$ é a proporção de funcionários que concordam.

A comparação entre o primeiro turno e mensalista encontra-se na Tabela 12, abaixo:

Tabela 12 - Comparação: primeiro turno e mensalista

\begin{tabular}{|c|c|c|c|c|c|}
\hline Questão & Variável & p-valor P1 & p-valor P2 & p-valor P3 & Resultado \\
\hline $\mathbf{1}$ & conhecimento & 15,9 & 91,5 & 13,3 & aceito \\
\hline $\mathbf{2}$ & conhecimento & 4,3 & 5,9 & 6,5 & rejeito \\
\hline $\mathbf{3}$ & comprometimento & 5,9 & 91,5 & 72,6 & aceito \\
\hline $\mathbf{4}$ & comprometimento & 86,9 & $*$ & 86,9 & aceito \\
\hline $\mathbf{5}$ & relacionamento & 86,2 & 72,6 & 85,9 & aceito \\
\hline $\mathbf{6}$ & custos & 2,8 & 13,2 & 91,5 & aceito \\
\hline $\mathbf{7}$ & custos & 2,8 & 32,8 & 69,2 & aceito
\end{tabular}


Tabela 12 - Comparação: primeiro turno e mensalista

\begin{tabular}{|c|c|c|c|c|c|}
\hline Questão & Variável & p-valor P1 & p-valor P2 & p-valor P3 & Resultado \\
\hline $\mathbf{8}$ & responsabilidade & 60,2 & 32,8 & 72,6 & aceito \\
\hline $\mathbf{9}$ & responsabilidade & 53,8 & 31,1 & 23,1 & aceito \\
\hline $\mathbf{1 0}$ & responsabilidade & 24,6 & 5,9 & 18,3 & aceito \\
\hline $\mathbf{1 1}$ & informação & 26,3 & 86,2 & 2,8 & aceito \\
\hline $\mathbf{1 2}$ & informação & 23,1 & 24,6 & 72,6 & aceito \\
\hline $\mathbf{1 3}$ & informação & 10,4 & 96,4 & 9,5 & aceito \\
\hline $\mathbf{1 4}$ & relacionamento & $*$ & 31,1 & 31,1 & aceito \\
\hline $\mathbf{1 5}$ & qualidade & $*$ & 57,9 & 57,9 & aceito \\
\hline $\mathbf{1 6}$ & qualidade & 90,5 & 11,9 & 19,3 & aceito \\
\hline $\mathbf{1 7}$ & relacionamento & 5,2 & 0,4 & 0 & rejeito \\
\hline $\mathbf{1 8}$ & relacionamento & 43,3 & 78,2 & 59,9 & aceito \\
\hline $\mathbf{1 9}$ & relacionamento & $*$ & $*$ & $*$ & aceito \\
\hline
\end{tabular}

* $\mathrm{O}$ asterisco representa que as respostas dos entrevistados foram exatamente as mesmas

$\mathrm{Na}$ comparação entre estes grupos pode-se considerar também os resultados satisfatórios, pois houve discordância em apenas duas questões. Os resultados foram diferentes especificamente nas questões 2 que também já foi motivo de discordância na comparação com outro grupo e na questão 17.

Sobre a questão 2, referente a variável conhecimento, os pesquisados também discordam entre si que a empresa utiliza ferramentas eficientes para facilitar o processo de geração e disseminação do conhecimento dentro da mesma.

Com relação a questão 17 , referente a variável relacionamento, os pesquisados discordam entre si que a média salarial aplicada pela empresa esteja acima da média paga pela região.

Nestes grupos a distorção ocorre principalmente entre os mensalistas, pois já fora comprovado em pesquisas promovidas pela empresa que a política salarial aplicada aos funcionários de chão de fábrica está acima da média da região, e também constatouse distorções em relação ao grupo mensalistas. Porém, na entrevista fornecida pelos executivos da empresa estas pequenas distorções já estão sendo corrigidas, cabe averiguar se este problema já foi abordado devidamente com os interessados.

\section{D) Comparação entre o segundo turno (t2) e o terceiro turno (t3)}

\section{Hipótese Científica:}


$\mathbf{H}_{\mathbf{0}}$ : Proporções de "discordância", "concordância" e "indiferente" são iguais para funcionários do segundo turno e terceiro turno.

$\mathbf{H}_{1}$ : Proporções de "discordância", "concordância" e "indiferente" são diferentes para funcionários do segundo turno e terceiro turno.

\section{Hipótese Estatística:}

$$
\mathbf{H}_{\mathbf{0}}:\left(\begin{array}{l}
P 1_{t 2} \\
P 2_{t 2} \\
P 3_{t 2}
\end{array}\right)=\left(\begin{array}{l}
P 1_{t 3} \\
P 2_{t 3} \\
P 3_{t 3}
\end{array}\right) \quad \mathbf{H}_{\mathbf{1}}:\left(\begin{array}{l}
P 1_{t 2} \\
P 2_{t 2} \\
P 3_{t 2}
\end{array}\right) \neq\left(\begin{array}{l}
P 1_{t 3} \\
P 2_{t 3} \\
P 3_{t 3}
\end{array}\right)
$$

Tal que $P 1$ é a proporção de funcionários que discordam, $P 2$ é a proporção de funcionários indiferentes e $P 3$ é a proporção de funcionários que concordam.

A Tabela 13, a seguir, apresenta a comparação entre o segundo e terceiro turno.

Tabela 13 - Comparação: segundo e terceiro turno

\begin{tabular}{|c|c|c|c|c|c|}
\hline Questão & Variável & p-valor P1 & p-valor P2 & p-valor P3 & Resultado \\
\hline $\mathbf{1}$ & conhecimento & 74,3 & 100 & 75,7 & aceito \\
\hline $\mathbf{2}$ & conhecimento & 71,7 & 4,9 & 6,1 & rejeito \\
\hline $\mathbf{3}$ & comprometimento & 14,7 & 43,2 & 14,7 & aceito \\
\hline $\mathbf{4}$ & comprometimento & 18,6 & $*$ & 18,6 & aceito \\
\hline $\mathbf{5}$ & relacionamento & 43,2 & $*$ & 43,2 & aceito \\
\hline $\mathbf{6}$ & custos & 21,7 & 29,3 & 52,5 & aceito \\
\hline $\mathbf{7}$ & custos & 100 & 100 & 100 & aceito \\
\hline $\mathbf{8}$ & responsabilidade & 3,5 & 14,7 & 0,8 & rejeito \\
\hline $\mathbf{9}$ & responsabilidade & 14,7 & 71,7 & 12,2 & aceito \\
\hline $\mathbf{1 0}$ & responsabilidade & 29,3 & 14,7 & 100 & aceito \\
\hline $\mathbf{1 1}$ & informação & 69,4 & 46,9 & 35,0 & aceito \\
\hline $\mathbf{1 2}$ & informação & 35,0 & 100 & 35,0 & aceito \\
\hline $\mathbf{1 3}$ & informação & 14,7 & 69,4 & 35,0 & aceito \\
\hline $\mathbf{1 4}$ & relacionamento & $*$ & $*$ & $*$ & aceito \\
\hline $\mathbf{1 5}$ & qualidade & 46,9 & $*$ & 46,9 & aceito \\
\hline $\mathbf{1 6}$ & qualidade & $*$ & 21,2 & 21,2 & aceito \\
\hline $\mathbf{1 7}$ & relacionamento & 46,9 & 59,9 & 100 & aceito \\
\hline $\mathbf{1 8}$ & relacionamento & 75,7 & 46,9 & 100 & aceito \\
\hline $\mathbf{1 9}$ & relacionamento & 46,9 & $*$ & 46,9 & aceito \\
\hline
\end{tabular}

* O asterisco representa que as respostas dos entrevistados foram exatamente as mesmas 
$\mathrm{Na}$ comparação entre o segundo e terceiro turno pode-se considerar os resultados satisfatórios, pois houve discordância apenas nas questões 2 e 8 .

$\mathrm{Na}$ questão 2, referente ao conhecimento, os pesquisados também discordam entre si que a empresa utilize ferramentas eficientes para facilitar o processo de geração e disseminação do conhecimento dentro da mesma. Novamente esta questão aparece como alvo de discordância na pesquisa o que ressalta a importância de se aprofundar mais nos possíveis problemas para esta repetição quase que sistemática dos resultados.

A questão 8 apresentou discordância quanto a preocupação da empresa em relação a segurança dos funcionários. É importante salientar que esta questão também já foi abordada na comparação entre o primeiro e segundo turno, e essa repetição justifica um maior aprofundamento de suas possíveis causas. Destaca-se que a segurança não pode ser vista como algo apenas físico, pois neste sentido observou-se nas entrevista com os executivos grande preocupação por parte da empresa, mas também como algo emocional. De modo geral como já constatado anteriormente em outros grupos, neste também houve pouca discordância quanto as questões elaboradas.

\section{E) Comparação entre o segundo turno (t2) e mensalista $(M)$}

\section{Hipótese Científica:}

$\mathbf{H}_{\mathbf{0}}$ : Proporções de "discordância", "concordância" e "indiferente" são iguais para funcionários do segundo turno e mensalista.

$\mathbf{H}_{1}$ : Proporções de "discordância", "concordância" e "Indiferente" são diferentes para funcionários do segundo turno e mensalista.

Hipótese Estatística:

$$
\mathbf{H}_{\mathbf{0}}:\left(\begin{array}{l}
P 1_{t 2} \\
P 2_{t 2} \\
P 3_{t 2}
\end{array}\right)=\left(\begin{array}{l}
P 1_{M} \\
P 2_{M} \\
P 3_{M}
\end{array}\right) \quad \mathbf{H}_{\mathbf{1}}:\left(\begin{array}{l}
P 1_{t 2} \\
P 2_{t 2} \\
P 3_{t 2}
\end{array}\right) \neq\left(\begin{array}{l}
P 1_{M} \\
P 2_{M} \\
P 3_{M}
\end{array}\right)
$$

Tal que $P 1$ é a proporção de funcionários que discordam, $P 2$ é a proporção de funcionários indiferentes e $P 3$ é a proporção de funcionários que concordam.

A Tabela 14 apresenta a comparação entre o segundo turno e mensalistas. 
Tabela 14 - Comparação: segundo turno e mensalista

\begin{tabular}{|c|c|c|c|c|c|}
\hline Questão & Variável & p-valor P1 & p-valor P2 & p-valor P3 & Resultado \\
\hline $\mathbf{1}$ & conhecimento & 8,9 & 76,4 & 4,7 & rejeito \\
\hline $\mathbf{2}$ & conhecimento & 0,2 & 53,9 & 0,6 & rejeito \\
\hline $\mathbf{3}$ & comprometimento & $*$ & 76,4 & 76,4 & aceito \\
\hline $\mathbf{4}$ & comprometimento & 42,1 & $*$ & 42,1 & aceito \\
\hline $\mathbf{5}$ & relacionamento & 76,4 & 8,6 & 22,6 & aceito \\
\hline $\mathbf{6}$ & custos & 91,2 & 22,6 & 36,3 & aceito \\
\hline $\mathbf{7}$ & custos & 21,1 & 37,2 & 51,0 & aceito \\
\hline $\mathbf{8}$ & responsabilidade & 08,6 & $*$ & 8,6 & aceito \\
\hline $\mathbf{9}$ & responsabilidade & 4,6 & 94,6 & 8,9 & rejeito \\
\hline $\mathbf{1 0}$ & responsabilidade & 37,2 & $*$ & 37,2 & aceito \\
\hline $\mathbf{1 1}$ & informação & 41,8 & 70,9 & 70,1 & aceito \\
\hline $\mathbf{1 2}$ & informação & 24,3 & 37,2 & 51,6 & aceito \\
\hline $\mathbf{1 3}$ & informação & 4,6 & 41,8 & 1,3 & rejeito \\
\hline $\mathbf{1 4}$ & relacionamento & $*$ & 8,6 & 8,6 & aceito \\
\hline $\mathbf{1 5}$ & qualidade & 53,9 & $*$ & 53,9 & aceito \\
\hline $\mathbf{1 6}$ & qualidade & 9,7 & 52,3 & 45,7 & aceito \\
\hline $\mathbf{1 7}$ & relacionamento & 42,1 & 1,3 & 0,7 & rejeito \\
\hline $\mathbf{1 8}$ & relacionamento & 24,3 & 91,2 & 91,2 & aceito \\
\hline $\mathbf{1 9}$ & relacionamento & 53,9 & $*$ & 53,9 & aceito \\
\hline $\mathbf{4}$ & & $*$ & & & \\
\hline
\end{tabular}

* O asterisco representa que as respostas dos entrevistados foram exatamente as mesmas

Os resultados obtidos na comparação entre o segundo turno e mensalistas foram os mais expressivos. Em cinco questionamentos houve discordância entre eles, especificamente nas questões $1,2,9,13$ e 17 .

Nas questões 1 e 2, referentes a variável conhecimento, os pesquisados discordam entre si que a empresa utilize de ferramentas eficientes para facilitar o processo de geração e disseminação do conhecimento dentro da mesma. E ainda que esta estimule uma cultura de aprendizagem, criação e compartilhamento deste conhecimento.

Sobre a questão 9, referente a variável responsabilidade, estes discordam entre si do compartilhamento de eventuais falhas no processo.

Com relação a questão 13, referente a variável informação, houve discordância sobre a eficiência das ferramentas utilizadas pela empresa para a comunicação com seus funcionários.

A questão 17, referente a variável relacionamento, os pesquisados discordam entre si que a média salarial aplicada pela empresa esteja acima da média paga pela região. 
Estas divergências podem estar ocorrendo pelo fato dos funcionários do segundo turno serem os mais novos da empresa, possuindo motivação inicial de trabalho, ou também destes terem seus anseios como segurança e reconhecimento respaldados pela empresa. Como já abordado anteriormente os mensalistas fazem parte do grupo em que a empresa está trabalhando para correção de algumas distorções que podem estar afetando sensivelmente este relacionamento.

É interessante observar que o segundo turno e os mensalistas, fazendo parte de áreas distintas, foram os que apresentaram as opiniões mais divergentes, diferentemente dos outros grupos analisados, porém é importante destacar que este fato não ocorreu em outras comparações entre grupos também distintos.

\section{F) Comparação entre o terceiro turno (t3) e mensalista $(M)$}

\section{Hipótese Científica:}

$\mathbf{H}_{\mathbf{0}}$ : Proporções de "discordância", "concordância" e "indiferente" são iguais para funcionários do terceiro turno e mensalista.

$\mathbf{H}_{1}$ : Proporções de "discordância", "concordância" e "indiferente" são diferentes para funcionários do terceiro turno e mensalista.

\section{Hipótese Estatística:}

$$
\mathbf{H}_{\mathbf{0}}:\left(\begin{array}{l}
P 1_{t 3} \\
P 2_{t 3} \\
P 3_{t 3}
\end{array}\right)=\left(\begin{array}{l}
P 1_{M} \\
P 2_{M} \\
P 3_{M}
\end{array}\right) \quad \mathbf{H}_{1}:\left(\begin{array}{l}
P 1_{t 3} \\
P 2_{t 3} \\
P 3_{t 3}
\end{array}\right) \neq\left(\begin{array}{l}
P 1_{M} \\
P 2_{M} \\
P 3_{M}
\end{array}\right)
$$

Tal que $P 1$ é a proporção de funcionários que discordam, $P 2$ é a proporção de funcionários indiferentes e $P 3$ é a proporção de funcionários que concordam.

A comparação entre o terceiro turno e mensalistas encontra-se na Tabela 15, a seguir: 
Tabela 15 - Comparação: terceiro turno e mensalista

\begin{tabular}{|c|c|c|c|c|c|}
\hline Questão & Variável & p-valor P1 & p-valor P2 & p-valor P3 & Resultado \\
\hline $\mathbf{1}$ & conhecimento & 7,9 & 79,3 & 3,8 & rejeito \\
\hline $\mathbf{2}$ & conhecimento & 1,3 & 9,1 & 19,0 & rejeito \\
\hline $\mathbf{3}$ & comprometimento & 37,7 & 73,5 & 40,8 & aceito \\
\hline $\mathbf{4}$ & comprometimento & 73,5 & $*$ & 73,5 & aceito \\
\hline $\mathbf{5}$ & relacionamento & 73,5 & 21,7 & 67,9 & aceito \\
\hline $\mathbf{6}$ & custos & 27,6 & 6,7 & 73,5 & aceito \\
\hline $\mathbf{7}$ & custos & 27,6 & 37,7 & 55,8 & aceito \\
\hline $\mathbf{8}$ & responsabilidade & 73,5 & 37,7 & 40,8 & aceito \\
\hline $\mathbf{9}$ & responsabilidade & 55,8 & 73,5 & 73,5 & aceito \\
\hline $\mathbf{1 0}$ & responsabilidade & $*$ & 37,7 & 37,7 & aceito \\
\hline $\mathbf{1 1}$ & informação & 31,0 & 79,3 & 27,6 & aceito \\
\hline $\mathbf{1 2}$ & informação & 7,9 & 37,7 & 19,8 & aceito \\
\hline $\mathbf{1 3}$ & informação & 55,8 & 31,0 & 9,1 & aceito \\
\hline $\mathbf{1 4}$ & relacionamento & $*$ & 21,7 & 21,7 & aceito \\
\hline $\mathbf{1 5}$ & qualidade & $*$ & $*$ & $*$ & aceito \\
\hline $\mathbf{1 6}$ & qualidade & 21,7 & 19,0 & 73,5 & aceito \\
\hline $\mathbf{1 7}$ & relacionamento & 21,7 & 9,8 & 2,3 & rejeito \\
\hline $\mathbf{1 8}$ & relacionamento & 19,8 & 6,7 & 92,1 & aceito \\
\hline $\mathbf{1 9}$ & relacionamento & $*$ & $*$ & $*$ & aceito \\
\hline
\end{tabular}

* $\mathrm{O}$ asterisco representa que as respostas dos entrevistados foram exatamente as mesmas

Na comparação entre o terceiro turno e mensalistas houve discordância em apenas três questões, na 1, 2 e 17.

Com relação a questão 1 e 2, referentes a variável conhecimento, os resultados foram os mesmos obtidos no grupo pesquisado anteriormente, onde estes discordam entre si que a empresa utilize de ferramentas eficientes para facilitar o processo de geração e disseminação do conhecimento dentro da mesma. E ainda que a empresa estimule uma cultura de aprendizagem, criação e compartilhamento deste conhecimento.

Sobre a questão 17, referente a variável relacionamento, os pesquisados discordam entre si que a média salarial aplicada pela empresa esteja acima da média paga pela região, esta também foi a opinião no grupo pesquisado anteriormente.

É importante destacar que o Teste Binomial só possibilita a análise de dois grupos simultaneamente, o que leva a uma pequena limitação. Porém, com o objetivo de aprofundar os resultados, a seguir se utilizará a técnica de Análise de Correspondência, que possibilita uma análise gráfica, com detalhes, das opiniões dos grupos.

\subsubsection{ANÁLISE DE CORRESPONDÊNCIA}


Análise de correspondência é uma técnica de análise fatorial para variáveis categóricas. Nessa análise, uma decomposição dos dados é obtida para se estudar a estrutura dos dados sem que um modelo seja hipotetizado ou que uma distribuição de probabilidade tenha sido assumida. O objetivo principal é a representação ótima da estrutura dos dados observados.

Com o propósito de facilitar a própria análise das informações, na demonstração dos resultados as questões foram agrupadas em conjuntos representando as variáveis estudadas:

- Conhecimento - questões 1 e 2;

- Comprometimento - questões 3 e 4;

- Relacionamento - questões 5, 14, 17, 18 e 19;

- Custos - questões 6 e 7;

- Responsabilidade - questões 8, 9 e 10 ;

- Informação - questões 11, 12 e 13;

- Qualidade - questões 15 e 16.

A seguir serão apresentados os resultados gráficos obtidos com a utilização desta técnica. Antes, é importante uma explicação mais detalhada sobre eles. Como já citado anteriormente este gráfico é uma representação das opiniões dos grupos pesquisados, com algumas diferenças em relação aos métodos anteriores, pois este permite uma análise simultânea das respostas. Dentro do gráfico observa-se o agrupamento ou afastamento dos grupos (T1 - primeiro turno, T2 - segundo turno, T3 terceiro turno e M - mensalista) sobre uma determinada questão. Por exemplo, R27, onde $R$ indica resposta, 2 se refere a questão número dois e 7 corresponde a escala sete.

Com a análise da variável conhecimento (Gráfico 1), compostas das questões 1 e 2, pode-se considerar que, no geral, os turnos compartilham da mesma opinião, já que os resultados obtidos os colocaram próximos ao centro. A exceção neste gráfico ficou com o grupo mensalista que ficou um pouco mais afastado do centro.

É importante destacar que este distanciamento não chega a ser significativo, mas deve ser levado em consideração por poder causar possíveis transtornos, tendo como base a importância desta variável. 
Outro aspecto interessante é que a diferença mais significativa no gráfico diz respeito ao grupo mensalista e ao terceiro turno onde as divergências nas opiniões foram mais evidentes. 
Gráfico 1 - Conhecimento

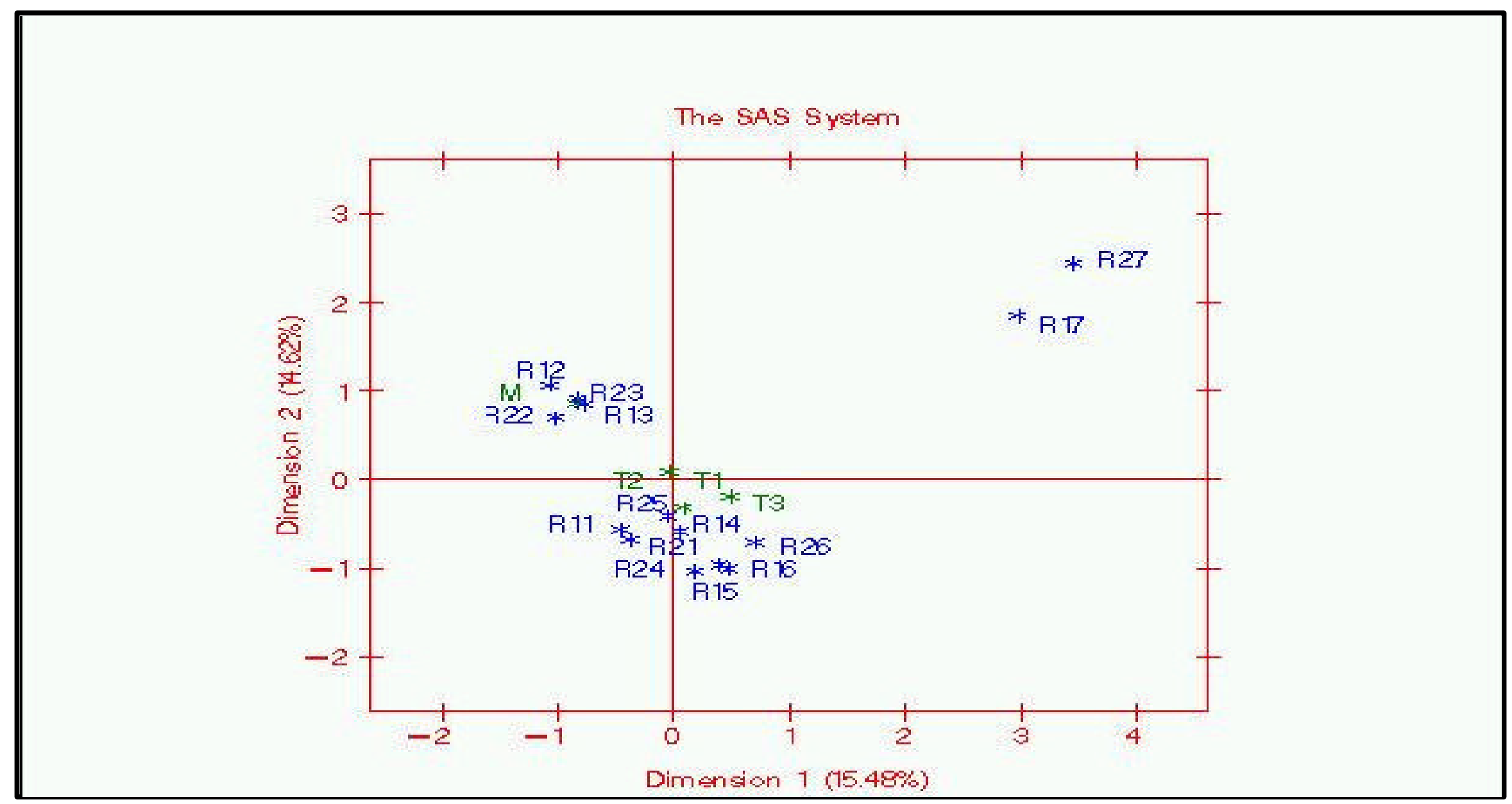


Com relação a variável comprometimento (Gráfico 2), compostas das questões 3 e 4, aplicadas nos questionários distribuídos aos funcionários da VW São Carlos, os resultados foram parecidos com os obtidos na primeira variável estudada, a do conhecimento, ou seja, de um modo geral os turnos compartilham da mesma opinião em relação a esta variável, pois estes se mantiveram próximos ao centro.

Nota-se que as respostas ficaram um pouco mais espalhadas do que as observadas na variável conhecimento, este fato ocorre pela escala de valores dados pelos grupos serem mais distribuídas, e ainda destaca-se que as opiniões mais divergentes entre os grupos ficaram entre os mensalistas e o grupo do segundo turno. 
103

Gráfico 2 - Comprometimento

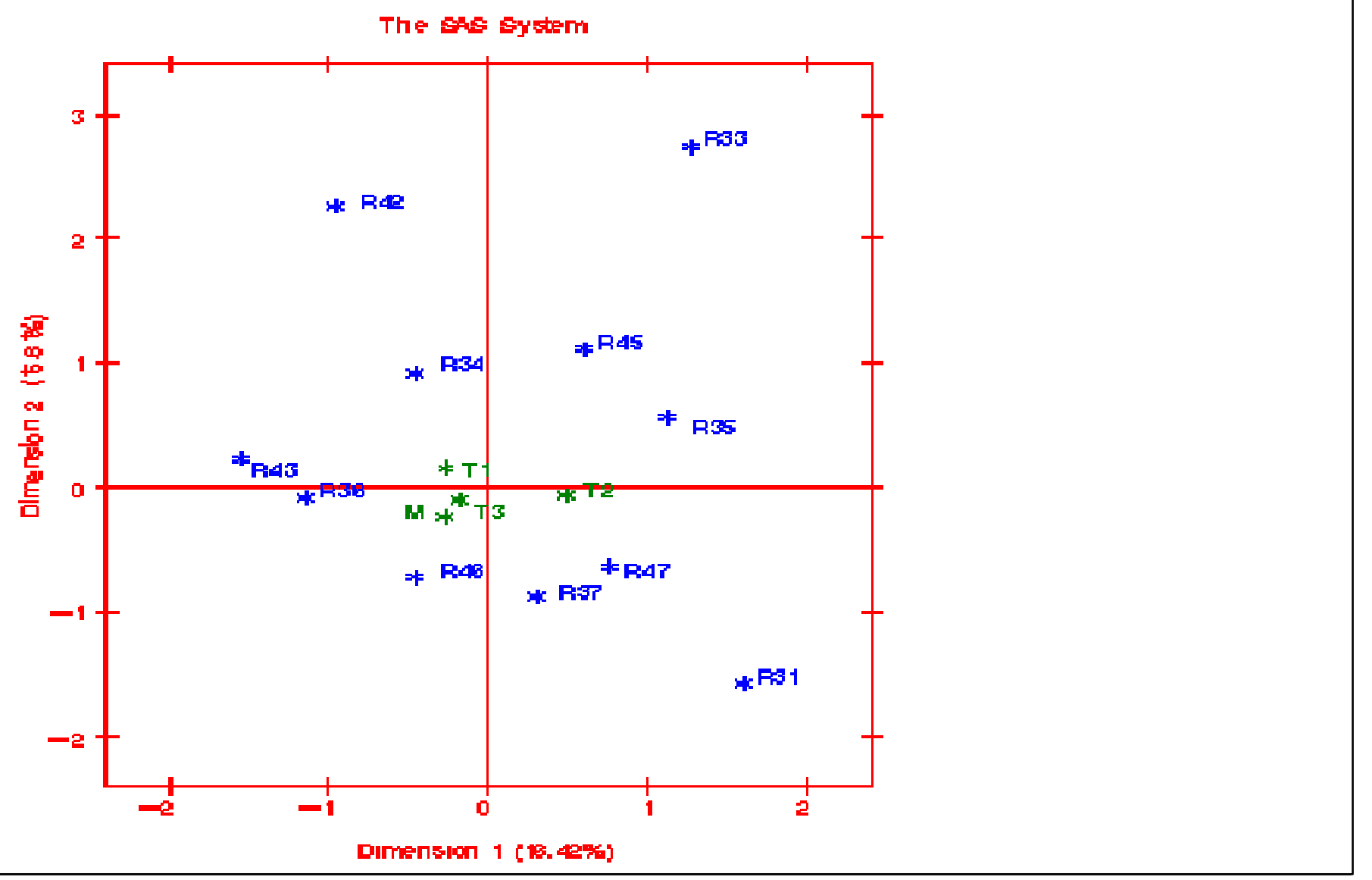


$\mathrm{Na}$ variável relacionamento (Gráfico 3), questões 5, 14, 17, 18 e 19, os resultados obtidos foram parecidos com os anteriores. Novamente, a maioria dos turnos compartilha quase que dá mesma opinião.

Os resultados dos grupos se concentraram próximos ao centro, com apenas algumas questões que se distanciaram, devido novamente as disparidades de algumas escalas atribuídas nas análises. Destaca-se que as diferenças mais significativas no gráfico, novamente, correspondem ao grupo mensalista e ao segundo turno. 
Gráfico 3 - Relacionamento

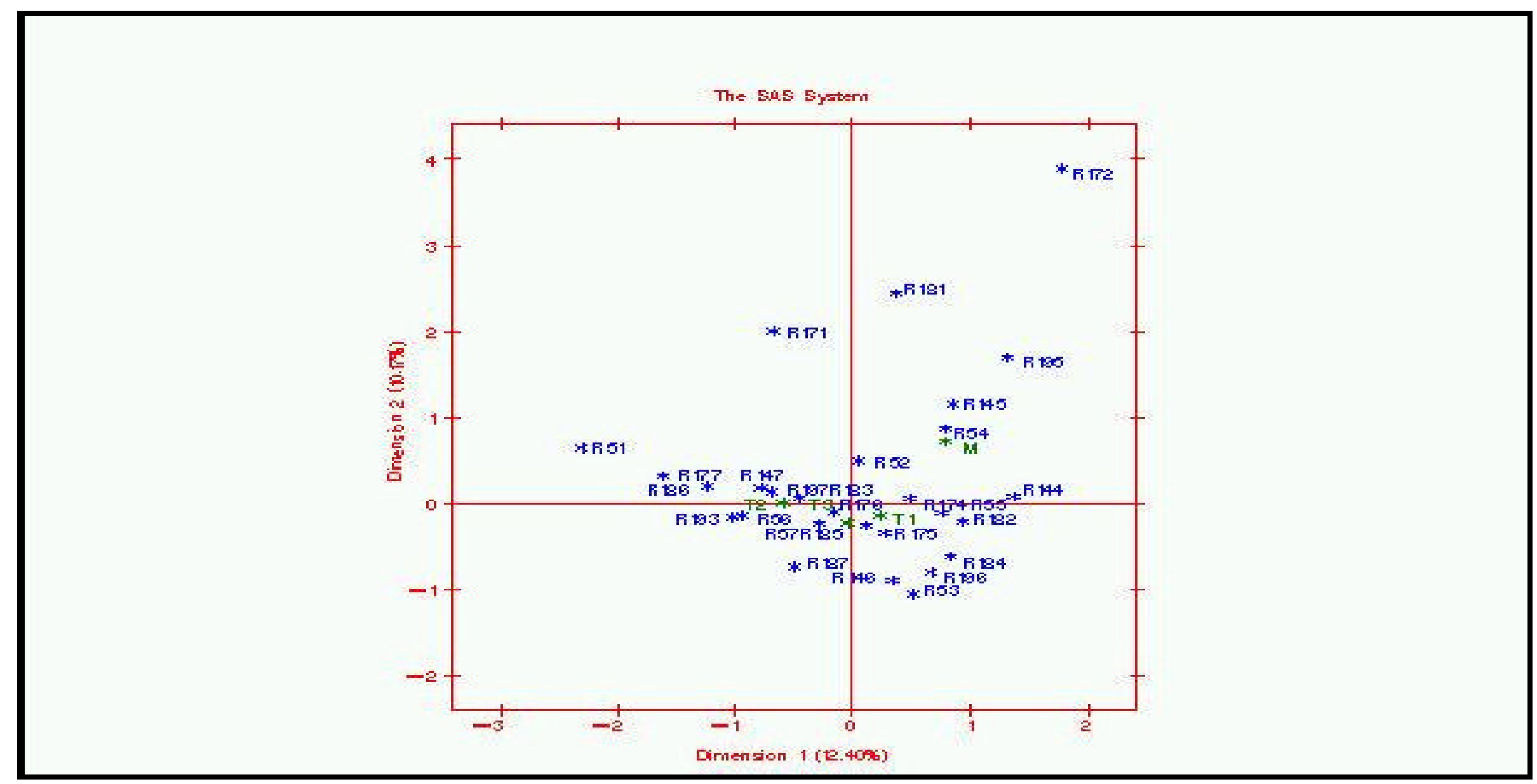


Ao analisar a variável custo (Gráfico 4), questões 6 e 7, pode-se chegar as seguintes considerações. No geral os grupos pesquisados compartilham das mesmas opiniões, pois em sua maioria mantiveram-se próximos ao centro do gráfico.

O destaque negativo com relação a análise desta variável fica por conta do terceiro turno que afastou-se um pouco do centro, porém este distanciamento, também, não chega a ser significativo. É importante destacar que a diferença mais significativa no gráfico corresponde ao grupo do segundo e terceiro turno. 


\section{Gráfico 4 - Custo}

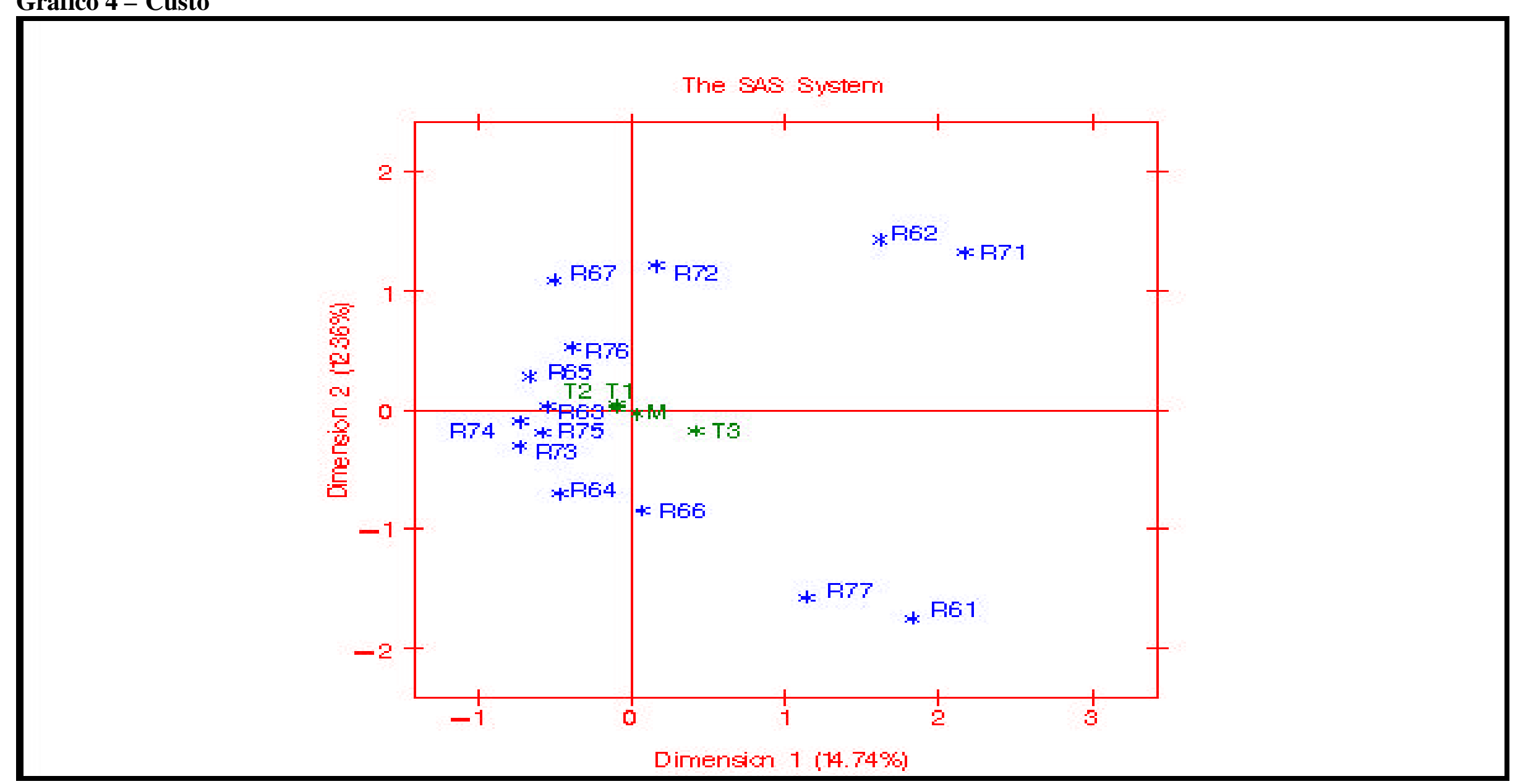


Na variável responsabilidade (Gráfico 5), questões 8, 9 e 10, no geral os grupos pesquisados compartilham das mesmas opiniões, mantendo-se em sua maioria próximos ao centro do gráfico, com exceção apenas dos mensalistas que se afastaram um pouco, porém este distanciamento, também, não chega a ser significativo.

Destaca-se que mais uma vez as opiniões mais divergentes foram as do grupo mensalistas e o grupo do segundo turno. 
Gráfico 5 - Responsabilidade

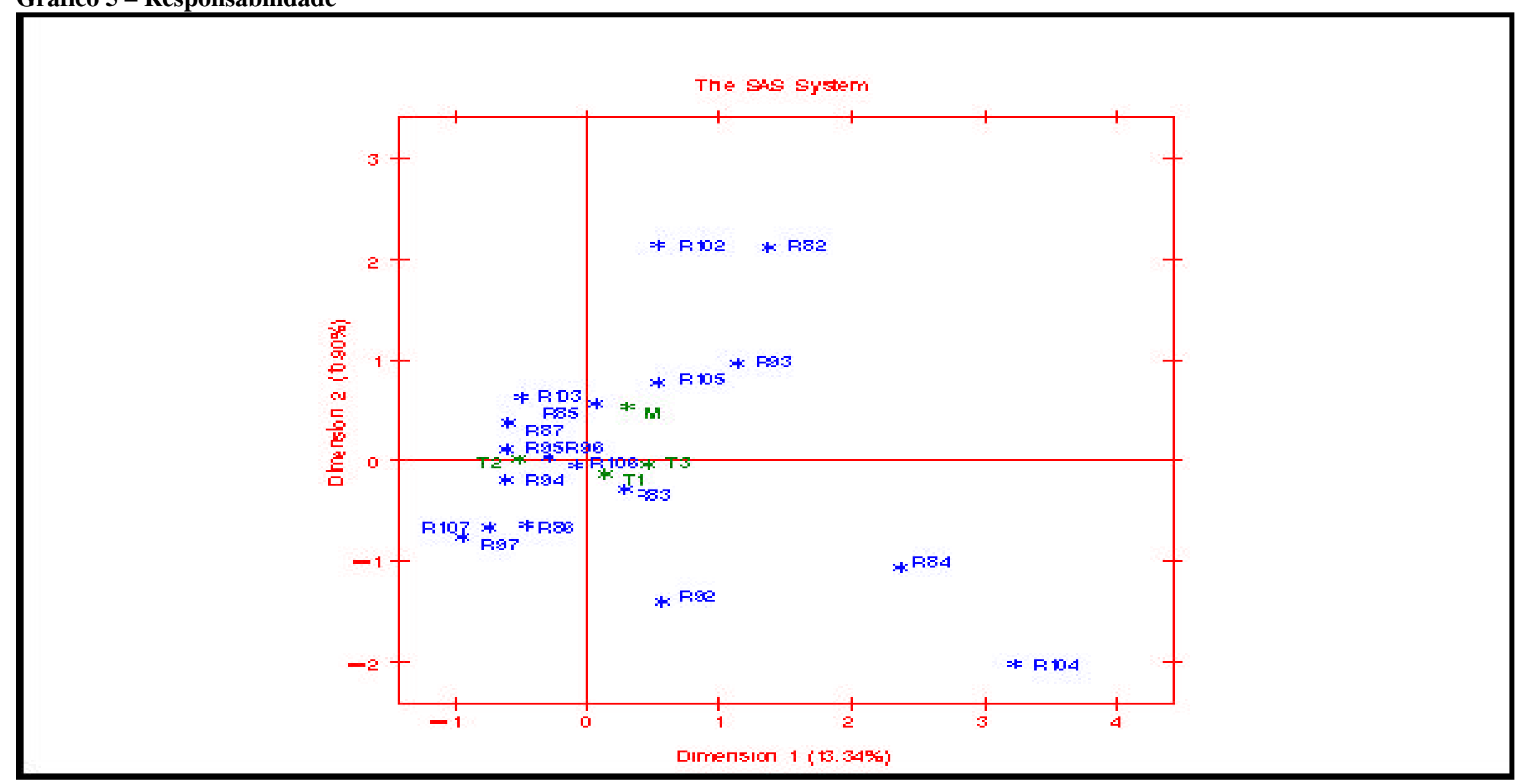


Com relação a variável informação (Gráfico 6), questões 11, 12 e 13, houve praticamente uma divisão nos resultados. Os grupos compostos do primeiro e segundo turno se mantiveram muito próximos um do outro, especificamente próximos também do centro. E o restante compostos de mensalistas e terceiro turno um pouco mais afastado deste, porém, também, próximos ao centro. A diferença mais acentuada ficou novamente a cargo dos mensalistas e do segundo turno. 
Gráfico 6 - Informação

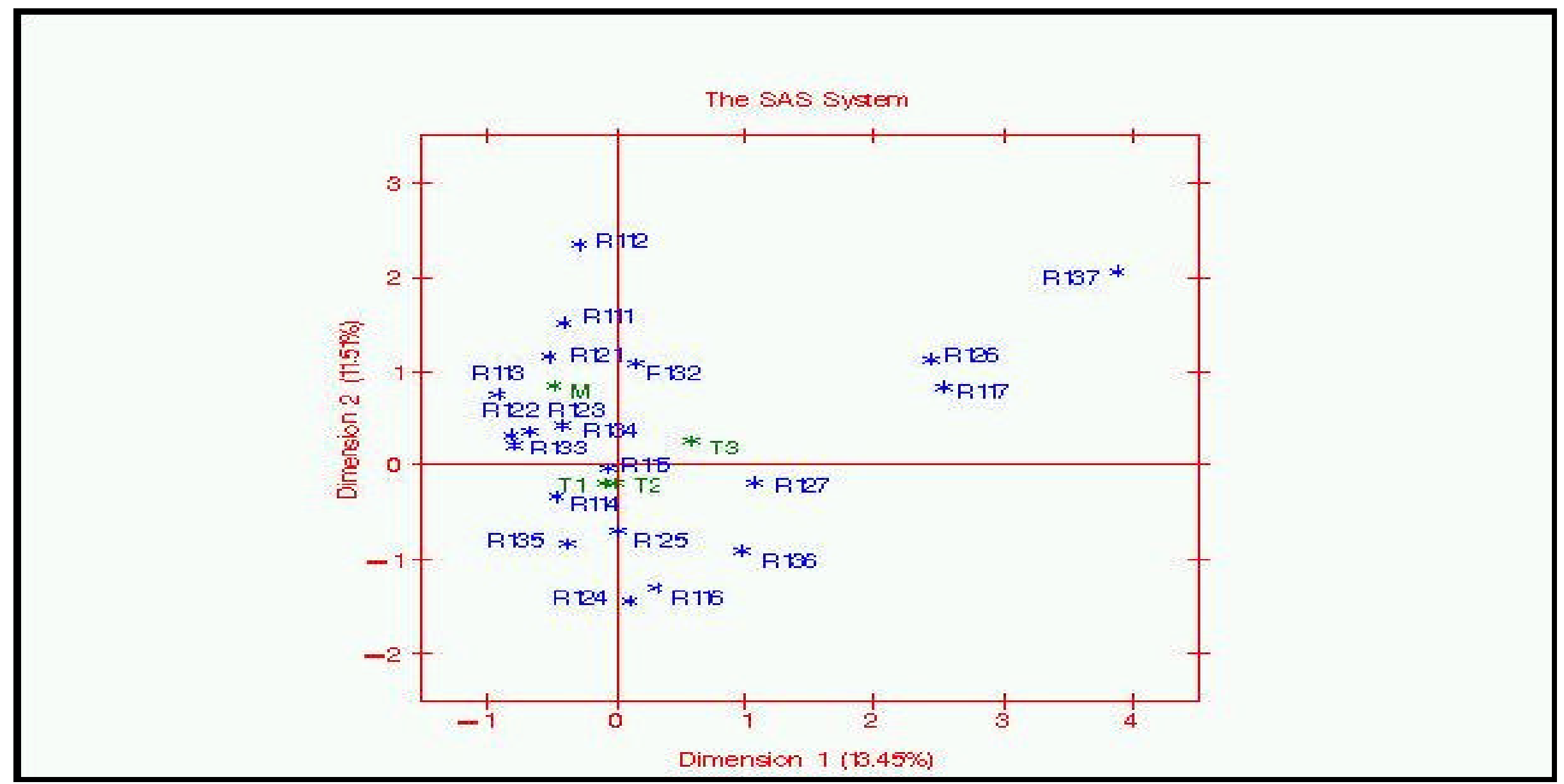


Na variável qualidade (Gráfico 7), questões 15 e 16, a maioria dos turnos compartilha quase que da mesma opinião, já que em sua grande maioria mantiveram-se próximos ao centro. A exceção neste gráfico ficou novamente com o grupo mensalistas que ficou um pouco mais afastado do centro, pois suas opiniões foram mais críticas em relação a esta variável.

É importante destacar que a opinião deste grupo é de extrema importância, pois em sua maioria são eles os responsáveis pelo acompanhamento e gerenciamento da qualidade antes, durante e depois dos processos. 
Gráfico 7 - Qualidade

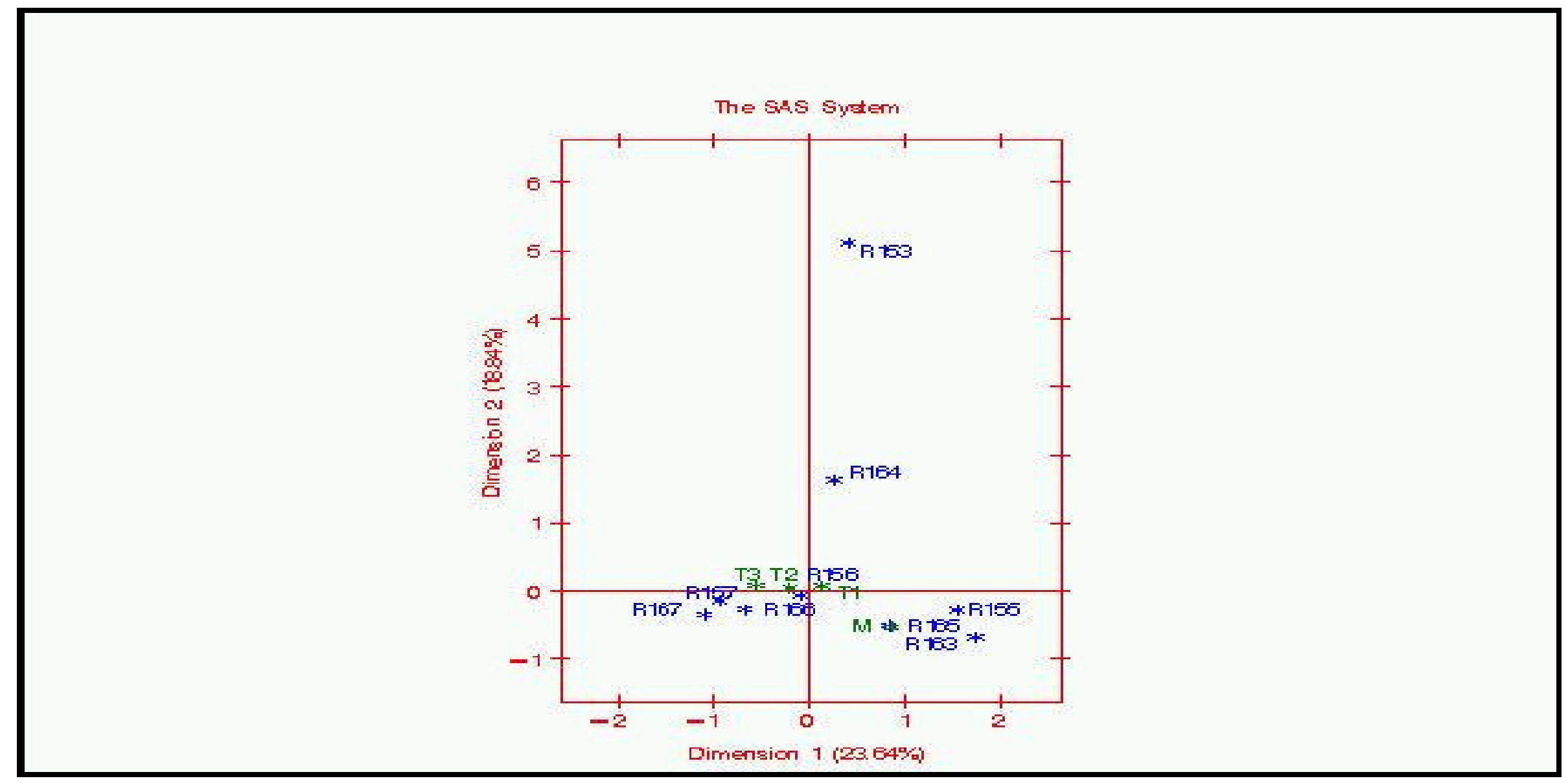


Ao analisar todas as variáveis pertinentes aos grupos pesquisados (Gráfico 8), pode-se chegar a seguinte consideração, aparentemente os turnos não divergem muito de suas opiniões ou visões por estarem bem próximos uns dos outros e próximos da média, há exceção apenas em algumas combinações de questões que se encontram um pouco distantes do centro, porém este distanciamento não chega a ser significativo. 


\section{Gráfico 8 - Total Funcionários}

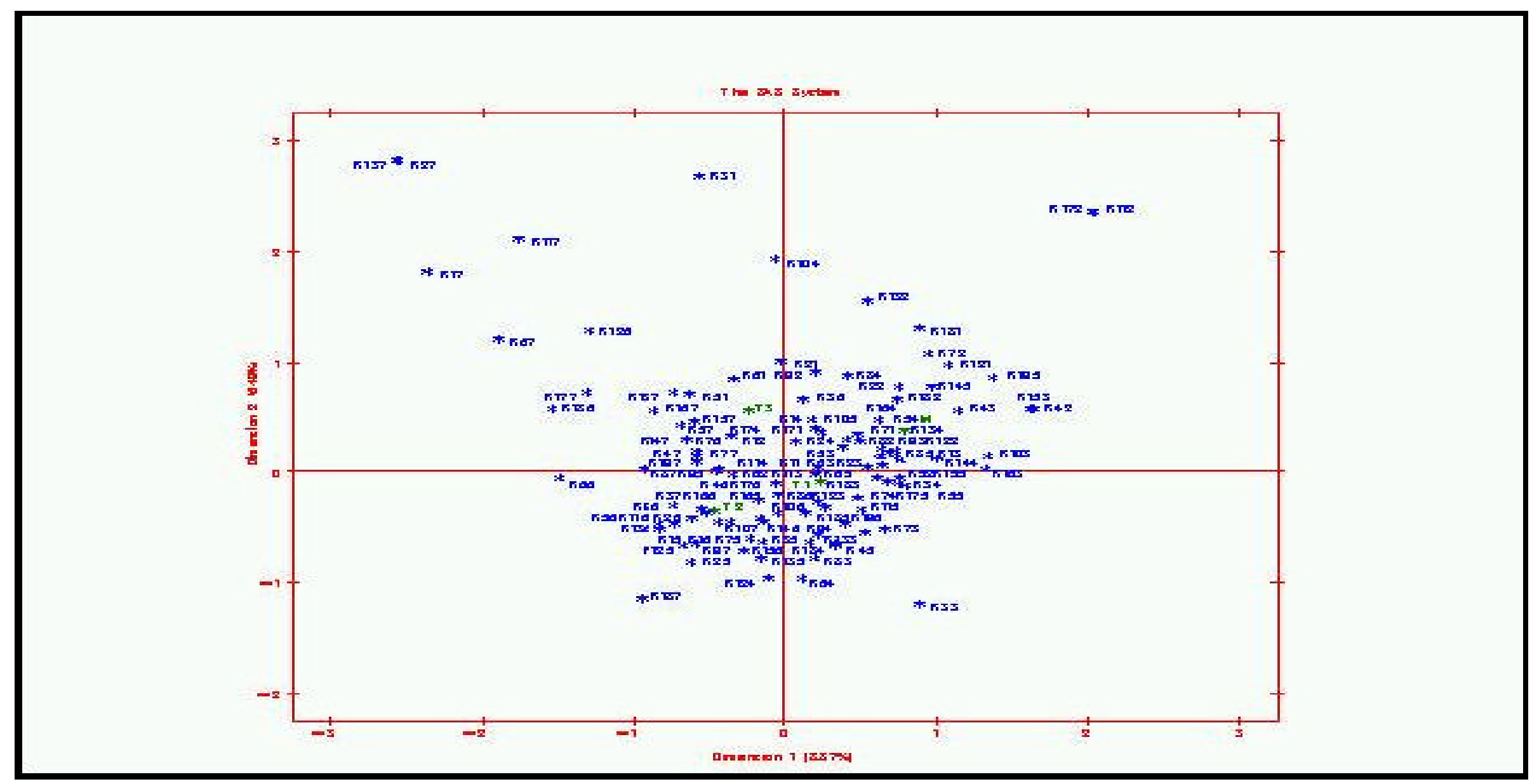


É importante salientar que todos os resultados obtidos nas análises dos gráficos dizem respeito somente a um grupo da pesquisa, os funcionários da fábrica, porém fundamentais para as considerações finais do trabalho.

Dando continuidade ao trabalho, a próxima análise corresponde a outro grupo de igual importância para a pesquisa, os fornecedores.

\subsection{GRUPO FORNECEDORES}

As questões referentes a parte II do questionário (Apêndice B), buscam verificar se os fornecedores da empresa, que fornecem componentes, materiais e serviços utilizados em sua cadeia produtiva, compartilham da mesma opinião em relação as variáveis apresentadas: conhecimento, comprometimento, relacionamento, custos, responsabilidade, informação e qualidade.

É importante destacar que os critérios utilizados para as análises dos dados estatísticos são os mesmos já discutidos no outro objeto de estudo deste trabalho, o grupo dos funcionários, onde estabeleceu-se o mesmo intervalo de valores para determinação do nível de concordância dos pesquisados: intervalo de valor inferior a 4 equivale ao nível de baixa concordância; intervalo de valor igual a 4 equivale ao nível de média concordância; intervalo de valor superior a 4 equivale ao nível de alta concordância.

A seguir será mostrada a Tabela 16 obtida no estudo, e posteriormente os gráficos representando também as respostas.

Tabela 16 - Porcentagem de cada questão para os fornecedores

\begin{tabular}{|c|c|c|c|c|}
\hline Questão & Variável & \%Discordância & \% Concordância & \% Mais ou Menos \\
\hline $\mathbf{1}$ & conhecimento & 0 & 78,9 & 21,1 \\
\hline $\mathbf{2}$ & conhecimento & 5,3 & 78,9 & 15,8 \\
\hline $\mathbf{3}$ & comprometimento & 0 & 100 & 0 \\
\hline $\mathbf{4}$ & comprometimento & 0 & 100 & 0 \\
\hline $\mathbf{5}$ & relacionamento & 0 & 94,4 & 5,6 \\
\hline $\mathbf{6}$ & custos & 0 & 94,7 & 5,3 \\
\hline $\mathbf{7}$ & custos & 0 & 78,9 & 21,1 \\
\hline $\mathbf{8}$ & responsabilidade & 0 & 94,7 & 5,3 \\
\hline $\mathbf{9}$ & responsabilidade & 0 & 100 & 0 \\
\hline $\mathbf{1 0}$ & responsabilidade & 10,5 & 57,9 & 31,6 \\
\hline $\mathbf{1 1}$ & informação & 5,3 & 84,2 & 10,5 \\
\hline $\mathbf{1 2}$ & informação & 0 & 100 & 0 \\
\hline
\end{tabular}


Tabela 16 - Porcentagem de cada questão para os fornecedores

\begin{tabular}{|c|c|c|c|c|}
\hline Questão & Variável & \%Discordância & \% Concordância & \% Mais ou Menos \\
\hline $\mathbf{1 3}$ & informação & 5,3 & 94,7 & 0 \\
\hline $\mathbf{1 4}$ & relacionamento & 0 & 89,5 & 10,5 \\
\hline $\mathbf{1 5}$ & qualidade & 0 & 100 & 0 \\
\hline $\mathbf{1 6}$ & qualidade & 0 & 100 & 0 \\
\hline $\mathbf{1 7}$ & relacionamento & 0 & 78,9 & 21,1 \\
\hline $\mathbf{1 8}$ & relacionamento & 5,3 & 89,5 & 5,3 \\
\hline $\mathbf{1 9}$ & relacionamento & 0 & 94,7 & 5,3 \\
\hline $\mathbf{2 0}$ & relacionamento & 0 & 89,5 & 10,5 \\
\hline
\end{tabular}

Com base nos dados obtidos através das respostas fornecidas pelos fornecedores, pôde-se chegar a seguintes observações. Todos os entrevistados deste grupo concordam com as observações levantadas nas questões. Este resultado é muito significativo para a empresa, pois evidencia de forma contundente que a empresa busca aplicar com seus fornecedores a filosofia de parcerias, muito enfatizadas nas entrevistas fornecidas por seus representantes.

Outro aspecto importante diz respeito ao gerenciamento eficaz destes relacionamentos por parte da empresa, já que estes são em sua maioria complexos e por isso respaldados por contratos formais.

Pode-se destacar que os resultados obtidos na análise da tabela são expressivos. Quando se compara este resultado com os conceitos principais da gestão do capital de relacionamento, passam a ser totalmente plausíveis, pois se enquadram realmente dentro do conceito de desenvolvimento de parcerias, onde as partes envolvidas buscam sistematicamente a eficiência administrativa.

A seguir será demonstrado o resultado obtido na Análise de Correspondência, porém cabe ressaltar que neste grupo não se utilizará o método de Teste Binomial, pois os fornecedores não foram separados.

\subsubsection{ANÁLISE DE CORRESPONDÊNCIA}

Para a análise de correspondência deste grupo as variáveis estudadas não serão separadas, mas sim analisadas em sua totalidade, tendo por base as respostas dos fornecedores (Gráfico 9). 


\section{Gráfico 9 - Total Fornecedores}

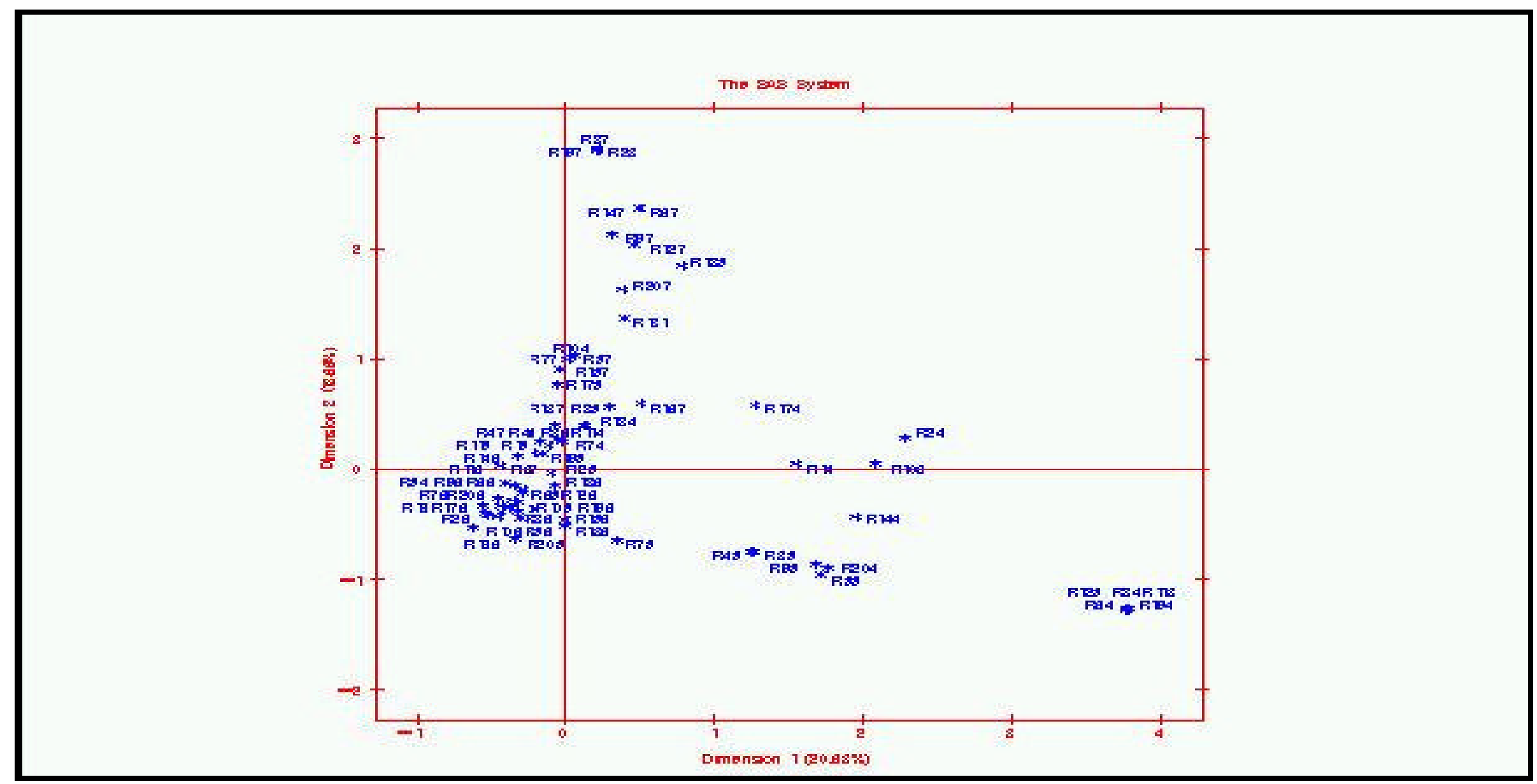


Ao analisar todas as variáveis pertinentes ao grupo fornecedores, chega-se as seguintes considerações, primeiramente os resultados deste grupo são muito parecidos com os dos funcionários por estarem bem próximos uns dos outros e próximos da média, em apenas algumas combinações de questões estas se encontram distantes do centro, isto ocorre pelo fato da escala de valores dada pelos fornecedores serem um pouco mais distribuídas, porém esta distribuição não é significativa.

Neste grupo encontram-se os fundamentos para um relacionamento empresarial. Nota-se que a empresa e seus fornecedores têm o mesmo foco, a formação de parcerias sustentáveis respaldadas em compromisso e confiança de ambas as partes.

Com o término das análises referentes as opiniões dos funcionários e fornecedores da Fábrica de Motores São Carlos, a seguir apresenta-se e discuti-se os resultados obtidos com as entrevistas fornecidas pelos executivos desta empresa, com o propósito de confrontar as visões de todos os grupos pertencentes a pesquisa quanto aos seus respectivos relacionamentos.

\subsection{ANÁLISE DOS DADOS - ENTREVISTAS}

A população pesquisada neste grupo foi pequena, pois o objetivo não era obter dados quantitativos e sim qualitativos, desta forma buscourse levantar as opiniões dos executivos da empresa sobre os questionamentos elaborados na condução do trabalho quanto as variáveis: conhecimento, comprometimento, relacionamento, custos, responsabilidade, informação e qualidade. Destaca-se que fora construído um roteiro de entrevista (Apêndice C), para melhor aproveitamento dos dados.

Conhecimento: com relação a variável conhecimento, os executivos destacam que a empresa estimula e promove a criação e compartilhamento do conhecimento com seus funcionários e fornecedores, através de várias ferramentas utilizadas pelo grupo, e que esta idéia está embutida dentro do conceito de parcerias.

A empresa também está sempre buscando as melhores práticas desenvolvidas no mercado, juntamente com as oportunidades de aplicá-las, sem que isto acarrete aumento de custos ou grandes investimentos, já que procura-se aproveitar ao máximo as competências, o potencial e o conhecimento de seus funcionários e fornecedores.

É importante destacar que a base deste conhecimento acontece principalmente por um sistema de informações entre todas as unidades da organização que 
compartilham experiências e idéias entre si, criando desta maneira uma memória organizacional disponível a todos.

Um dos problemas enfrentados está relacionado diretamente ao idioma não dominado por todos dentro da organização, tendo em vista o tamanho do grupo presente em vários países com línguas diferentes. A empresa, também, ainda não utiliza todo o conhecimento disponível, desta forma ainda a espaço para melhorias.

Com relação às ferramentas utilizadas pela empresa, para facilitar o processo de geração e disseminação do conhecimento com seus funcionários e fornecedores, os entrevistados foram categóricos em afirmar que existem várias ferramentas utilizadas neste sentido cmo: instrumentos de comunicação, Gráfico de Pareto, diagrama de causa e efeito e Poka-Yoke ${ }^{1}$.

Outro exemplo é o programa de geração de idéia, onde o funcionário é estimulado a dar sugestões de melhoria dentro da organização, fornecendo desta maneira material para a criação de um banco de dados virtual onde todo o grupo possui acesso as melhores práticas desenvolvidas para se melhorar o produto ou indicadores. É importante destacar que os fornecedores também são incentivados a participar deste processo através dos sistemas de informações da empresa.

As observações descritas anteriormente foram feitas por pessoas que representam a empresa, suas considerações foram bem argumentadas e discutidas, porém quando se analisa os resultados obtidos nos outros métodos de pesquisa fica claro que esta visão não é compartilhada pela maioria dos funcionários, onde praticamente em todos os turnos evidenciourse algum tipo de problema neste sentido.

Comprometimento: quanto ao comprometimento, os executivos fazem uma distinção importante a se destacar em relação a diferença de colaboração de funcionários e fornecedores com a empresa.

Os entrevistados afirmam que em eventuais necessidades a colaboração dos funcionários não é total, não existe uma unanimidade neste sentido, já que a colaboração dos funcionários não é algo tão espontâneo como se gostaria, porém um grupo significativo de pessoas está sempre pré-disposto a auxiliar a empresa. É importante destacar que existe a possibilidade de melhorar esta situação, por isso a empresa está buscando dentro do possível revertê-la.

\footnotetext{
1 Técnica de garantia da qualidade desenvolvida no Japão nos anos sessenta, onde a idéia principal é mostrar que o ser humano é passível de cometer erros, e que esses erros podem ser facilmente detectados e corrigidos através da utilização de alguns mecanismos muito simples (SHINGO, 1997).
} 
Quanto a colaboração dos fornecedores existe uma flexibilidade maior, ou seja, não existem problemas significativos.

A empresa conta com a colaboração dos funcionários para alertar eventuais problemas, neste sentido existe um grupo de técnicos responsáveis que analisam os problemas existentes e ainda busca meios para solucioná-los. Uma das ferramentas mais utilizadas é o sistema Poka-Yoke, cujo objetivo é auxiliar os funcionários em processos que eventualmente poderiam ocorrer falhas. Destaca-se também que a empresa busca incentivar este alerta por parte dos funcionários evitando que os erros passem para frente, o que pode acarretar prejuízos maiores.

Os fornecedores também colaboram com a empresa no alerta de eventuais problemas, embora exista a necessidade de melhorar a qualidade do produto.

Com relação a variável comprometimento pode-se chegar a algumas considerações importantes. Existe divergência de opiniões entre empregados e empregador com relação ao comprometimento, onde na visão da empresa está aquém do ideal, porém deixa claro que pode ser melhorado, enquanto que na visão dos funcionários estão sempre colaborando com a empresa.

Neste caso específico pode estar ocorrendo, de ambas as partes, um desencontro de expectativas, seria interessante a empresa deixar mais evidente suas expectativas e anseio e tornar mais clara sua idéia de comprometimento, já que aparentemente ambos se consideram corretos. Porém, é importante destacar que a empresa considera satisfatório o comprometimento dos funcionários e fornecedores no alerta a eventuais problemas durante o processo produtivo.

Relacionamento: Para os entrevistados, o relacionamento da empresa com seus funcionários e fornecedores é um relacionamento de parcerias, onde todos trabalham em prol de um mesmo objetivo que é atender os volumes de produção com a qualidade necessária. Porém, admitem que o relacionamento com os funcionários precisa ser melhorado, esta afirmação destoa dos resultados obtidos através dos questionários aplicados aos funcionários, onde detectourse discordâncias nestas mesmas questões.

Com relação aos fornecedores este relacionamento é satisfatório, pois a empresa tem procurado formar parcerias e alianças estratégicas, melhorando e estreitando, assim, os laços entre as empresas. É importante destacar que a empresa conta com um total de 110 fornecedores, porém um mesmo fornecedor pode fornecer 
mais de um item à empresa. Um aspecto positivo é que esta visão também é compartilhada pelos fornecedores.

Segundo os entrevistados houve progresso quanto ao relacionamento entre os setores da empresa, mantendo-se dentro das expectativas. Porém existe a necessidade de melhorar a sinergia entre os departamentos e ainda que todos devem ter consciência de suas obrigações e ponderações em relação ao produto final. Durante as análises dos questionários observou-se esta dificuldade de relacionamento entre os setores da empresa, por isso seria um importante ponto a ser melhorado, pois na construção do trabalho constatou-se a importância em se possuir um bom relacionamento entre clientes e fornecedores internos. Mas, um passo muito importante já fora dado neste sentido, o reconhecimento do problema por parte da empresa que está procurando melhorá-lo.

Outro fator importante a ser analisado na variável relacionamento diz respeito aos salários pagos. Na opinião dos entrevistados, a média salarial aplicada está acima da média de mercado, havendo algumas raras exceções e a mesma está buscando acertar estas diferenças. Porém, é importante destacar que a empresa realiza pesquisas locais com concorrentes do mesmo tipo de produto (autopeças e montadoras). Estas observações, também, foram encontradas na análise dos questionários, com um resultado mais expressivo no grupo mensalista.

Quanto aos serviços prestados por seus funcionários e fornecedores, os entrevistados concordam que a empresa reconhece esses serviços. Com relação aos funcionários a empresa possui ferramentas formais de reconhecimento, como o sistema de avaliação de desempenho e o programa de geração de idéias, onde se realiza um evento comemorativo aos funcionários que se destacaram durante o ano.

Existe também um evento de reconhecimento anual para premiar os melhores fornecedores que mantiveram ou melhoraram seus índices de qualidade e ainda os que entregaram seus produtos no prazo estabelecido pela companhia.

Destaca-se a importância da empresa reconhecer os serviços prestados por seus funcionários, porém aquele reconhecimento às vezes até que informal pode fazer uma diferença significativa e trazer melhores resultados, pois alguns grupos que participaram das análises não se sentem confortáveis com o reconhecimento por parte da empresa.

Para manter um bom relacionamento com seus fornecedores, a empresa adquire uma cota mínima mensal de produtos, através de contratos conhecidos como 
Relising, onde existe uma programação de quatro semanas de antecedência com os fornecedores para este conseguir prover a demanda. É importante destacar que a empresa busca utilizar-se de dois fornecedores para cada produto e que todas as transações são realizadas através de contratos formais, independente do grau de parceria.

Por conta da relação de parcerias estabelecidas, a empresa procura, na maioria das vezes, fornecedores já conhecidos para realização de novos projetos, o que reduz conseqüentemente os custos, já que os parceiros conhecem o produto e os padrões da companhia. Esta afirmação vem ao encontro dos conceitos de parcerias observados durante a revisão bibliográfica, com um aspecto positivo, pois no grupo fornecedores os resultados foram satisfatórios. Destaca-se que os "fornecedores problemas" para a empresa são trabalhados para se retirarem da parceria.

Um aspecto importante a ser observado é que o conceito relacionamento é amplo e complexo por isso foi analisado em partes, pois existem várias situações ou problemas que podem afetá-lo direta ou indiretamente. Neste sentido pode-se constatar que algumas destas situações foram detectadas na análise do trabalho e que podem vir a afetar o relacionamento da empresa principalmente com seus funcionários. Não existe um iminente estado de alerta em toda a empresa, de modo geral os resultados foram satisfatórios e são apenas alguns grupos separados que requerem maior atenção.

Custos: Para os entrevistados, na eventualidade de fabricação de novos produtos e conseqüente treinamento, a idéia da empresa é fornecê-lo sempre que necessário, tanto aos funcionários como aos fornecedores. Porém, durante as análises dos resultados esta opinião não foi compartilhada por alguns dos grupos pesquisados, principalmente os dos funcionários.

Com relação aos funcionários eles utilizam o sistema on the job que possibilita trabalharem por toda a extensão de suas linhas, não ficando somente em único posto como no passado, isto possibilita a familiarização do empregado com todos os processos de montagem necessários para se produzir um motor, minimizando desta forma possíveis problemas com qualidade e refugo.

Já para os fornecedores a empresa fornece seu produto acabado para que este analise os resultados de seus componentes dentro dos motores.

Na opinião dos entrevistados, a empresa utiliza-se de uma política de redução de custos permanente, redução esta que passa por todos os insumos utilizados no processo de produção, desde água e luz até funcionários. Para eles, esta política tem se 
mostrado eficiente em relação ao cumprimento de seus objetivos, porém a empresa destaca que por causa da desvalorização do dólar frente ao real ela não conseguiu fechar no azul no ano de 2005.

Um dos métodos utilizados para esta redução é a otimização de processos, o que aumenta a produtividade juntamente com o aumento da sinergia e oportunidades de melhorias. É importante destacar que estas políticas têm se mostrado eficiente através da utilização de ferramentas como os PMC (Processo de Melhoria Contínua) e geração de idéias.

Outra prática utilizada para redução de custos é repassar ou compartilhar com os fornecedores os custos para o desenvolvimento de novos produtos. Porém, é importante destacar que cada fornecedor é tratado diferentemente levando-se em consideração principalmente o tipo de contrato firmado com a área de compras corporativas da organização. Estes contratos são extensos e detalhados, e mesmo sendo corporativos, a empresa pode exigir algumas premissas como qualidade, tempo de entrega, etc.

É importante destacar que, na busca por competitividade, as políticas de redução de custo da empresa são as mesmas utilizadas no mercado em geral. Outro fato importante a destacar diz respeito as reestruturações propostas publicamente pela empresa, como redução de encargos trabalhistas, nova formatação para o banco de horas e redução do quadro de funcionários, com o intuito de ser mais competitiva, porém estas propostas de reestruturação podem vir a afetar o relacionamento entre empresa e empregados.

Com relação aos fornecedores estas práticas são compatíveis com os princípios de parcerias observados durante a construção do trabalho, principalmente no que diz respeito a redução e compartilhamento de custos, conceito principal dos consórcios modulares.

Responsabilidade: nesta variável as questões se referem a responsabilidade por falhas no processo, ao prazo de entrega dos produtos, a relação da empresa com a integridade e saúde dos seus funcionários.

Segundo os entrevistados, na possibilidade de eventuais falhas no processo, a responsabilidade por tal será identificada, pois se as falhas forem do processo de produção é a empresa que buscará esclarecer o problema internamente utilizando-se da estrutura hierárquica existente (líderes, monitores e auditores) e, estes irão rastrear as causas e orientar as pessoas envolvidas, sem punição. Esta opinião não foi totalmente 
compartilhada especificamente pelo grupo dos mensalistas, composto em sua maioria por pessoas que trabalham nas áreas de qualidade, engenharia e logística.

Se a falha for do fornecedor o processo de identificação é similar, o que difere é a punição, pois uma vez o fornecedor sendo o causador da falha, a empresa irá debitar dele as eventuais perdas.

Quanto a responsabilidade por parte da empresa no prazo de entrega dos produtos às plantas da organização, os entrevistados concordaram que esta é uma busca contínua e também seu principal compromisso.

Sobre a questão integridade e saúde de seus funcionários, a empresa está sempre preocupada. Para minimizar ao máximo os problemas desta ordem a empresa fornece equipamentos de segurança EPI (equipamento de proteção individual), adequa postos de trabalhos as necessidades destes, faz auditorias de segurança permanentes, realiza a semana de prevenção de acidentes com ilustrações e peças de teatro. Caso haja necessidade, conversa diretamente com os empregados envolvendo-os numa mudança de hábitos mais seguros e conscientes e, ainda cria palestra sobre problemas relacionados a saúde fora da empresa que possam comprometer a integridade dos funcionários, como Aids e Dengue.

Informação: a empresa criou estratégias para manter uma boa relação de informação com seus funcionários e fornecedores. Com relação aos funcionários a empresa comunica-se de uma forma mais ampla semestralmente, através dos quadros de aviso, reuniões de trabalhos e jornal da companhia. Já, com os fornecedores através dos planos de produção e contatos diários.

Utilizando as mesmas ferramentas citadas acima, a empresa também comunica de forma clara suas expectativas sobre seus funcionários e fornecedores. Segundo os entrevistados, a empresa lembra seus funcionários que ela os paga para que estes cumpram com seus deveres, havendo um processo claro de comunicação. Porém, é importante ressaltar que a eficiência desta comunicação pode ser melhorada.

Para os entrevistados a empresa utiliza-se de ferramentas eficientes na comunicação com seus funcionários e fornecedores como: liderança, gerência de fábrica, quadros de aviso, sistema oito passos, jornal rádio peão e sindicato para informação dos funcionários.

Com relação aos fornecedores o processo de informação é associado diretamente ao cliente, a produção, qualidade e a logísticas que estão interligadas simultaneamente, e o Helpline e o sistema RI (relatórios de inspeção). 
É importante destacar que alguns grupos pesquisados discordam que as informações cheguem de uma maneira eficiente e discordam também da qualidade das ferramentas utilizadas. Uma afirmação dos executivos deixou transparecer a existência de possíveis conflitos, ao se afirmar que a empresa lembra seus funcionários que ela os paga para que estes cumpram com seus deveres, este tipo de comunicação não é compatível com os conceitos de parcerias vistos durante a construção do trabalho.

Qualidade: conforme os entrevistados, todas as peças recebidas são certificadas antes mesmo dos fornecedores começarem a fornecê-las.

Os indicadores de qualidade melhoraram nos últimos anos, principalmente por conta do conhecimento dos empregados, adoção de novas medidas de contenção, a melhora dos processos produtivos dos fornecedores, e uma divulgação da cultura voltada para a qualidade dos produtos, juntamente com a formação das parcerias desenvolvidas com os fornecedores e um foco maior nos processos internos e externos.

Imagem: os entrevistados afirmaram categoricamente ser a marca da empresa reconhecida e respeitada no mercado. Recentemente a empresa foi avaliada pela Top of mid como a primeira montadora de veículos na mente dos consumidores, este fato ocorre a exatamente 15 anos consecutivos. A marca está associada à durabilidade, praticidade, robustez, confiança, baixa manutenção e segurança dos produtos.

Para tanto as parcerias formadas pela empresa têm se mostrado importante. Conforme os entrevistados, a empresa se encontra na posição atual graças também a elas, como o caso do Total Flex, desenvolvido em conjunto com outra empresa brasileira. Por isso, o foco principal hoje para a empresa é a questão da formação de parcerias.

Durante as análises e discussões dos resultados pode-se observar que de modo geral os resultados foram satisfatórios, já que a maioria dos entrevistados concorda com os questionamentos elaborados, porém com algumas ressalvas, pois alguns grupos estão em possível estado de atenção que pode com o tempo vir a contaminar o restante da empresa. Sugere-se que a empresa observe-os mais atentamente com o propósito de melhorá-los.

É importante destacar que em alguns casos a empresa já detectou problemas e está buscando contorná-los, isto é o primeiro passo na busca de um bom clima organizacional. 
No próximo capítulo serão discutidas as considerações finais referentes ao trabalho, com algumas análises mais profundas e sugestões em torno dos resultados obtidos. 


\section{CAPítulo 7}

\section{CONSIDERAÇÕES FINAIS}

Neste capítulo apresentam-se as considerações finais relacionadas aos objetivos do trabalho, onde se confrontam as expectativas inicias propostas na introdução e metodologia da pesquisa com os resultados encontrados nas análises de resultados, somando-se a estas análises possíveis contribuições ao assunto principal, futuras pesquisas sobre o assunto abordado e por último descrever limitações encontradas no decorrer do trabalho.

A partir da revisão bibliográfica observada na construção dos capítulos referentes a estrutura deste trabalho, constata-se a importância do capital de relacionamento dentro das organizações, onde a busca por uma maior eficiência sobre a gestão deste importante capital passou a ser uma busca constante por parte das empresas.

Este é o novo cenário mundial onde as organizações estão inseridas, buscando constantemente se adaptar a esta nova situação. Porém, para as indústrias brasileiras este novo cenário surge em decorrência da liberação de mercado iniciada no Brasil a partir da década de 90, quando o mercado, em especial o automobilístico, deixou de estar protegido e novas empresas se instalaram no país, e aquelas que aqui se encontravam foram obrigadas a atualizarem sua tecnologia e estratégias produtivas. A partir desta nova realidade observa-se o surgimento de parcerias estratégicas e um movimento para melhorar o relacionamento entre fornecedores, montadoras e funcionários.

Com base nesta nova tendência, pode-se afirmar que as indústrias multinacionais com atuação no Brasil passaram a buscar alternativas que as tornem mais competitivas diante de uma economia globalizada, priorizando seus focos na redução de custos, que necessariamente passam por uma mudança cultural sobre seus relacionamentos. 
Sobre esse aspecto, a empresa em análise passou a ter como principal estratégia competitiva à valorização do setor de manufatura, procurando preparar todos os funcionários do chão de fábrica para os novos conceitos de fabricação, que são baseados no Sistema de Produção Enxuta, tentando assim recuperar e manter sua posição no mercado nacional, aproveitando ao máximo o conhecimento de seus funcionários, com programas de incentivos financeiros a idéias que venham a reduzir custos em seus processos ou produto final, juntamente com o estreitamento de seu relacionamento com funcionários e fornecedores.

É importante destacar que estas mudanças são aplicadas em todas as plantas da empresa, estendendo, portanto, para o estudo de caso deste trabalho, a Fábrica de Motores São Carlos, onde procurou-se analisar as dimensões e qualidades do relacionamento desta empresa frente a esta mudanças. A seguir segue uma análise dos resultados encontrados na pesquisa, juntamente com os objetivos propostos.

O objetivo principal deste trabalho foi verificar como esta empresa, conceituada e com ótimos índices de qualidade, gerencia seu capital de relacionamento, e ainda buscar identificar os elementos que compõem este importante capital.

Com base nesta proposta, pode-se afirmar que os resultados foram alcançados, pois foi possível identificar os principais elementos que constituem o capital de relacionamento: conhecimento, comprometimento, relacionamento, custo, responsabilidade, informação e qualidade. Ficou evidente na análise deste trabalho que a empresa não possui uma política específica para gerenciar seu capital de relacionamento. Porém, é importante ressaltar que a mesma tem os fundamentos e os elementos para que isso ocorra, bastando apenas redirecionar seus esforços e ferramental para este propósito.

A empresa utiliza-se de ferramentas convencionais e algumas novas como o programa de geração de idéias, que auxilia no melhor aproveitamento intelectual de seus funcionários, convergindo com seus interesses principais na busca da eficiência e redução de custos.

Outro resultado importante a destacar é que mesmo sem uma política específica direcionada ao capital de relacionamento, a empresa indiretamente direciona seus trabalhos a este respeito, um exemplo que evidencia esta situação é o grande número de parcerias formadas com seus fornecedores. Este movimento indica uma típica ação de estreitamento das relações, é importante destacar que a empresa possui 
precauções inerentes as parcerias, ou seja, todos os acordos são respaldados por contratos detalhados buscando desta forma maior segurança para as partes.

Ainda com relação aos fornecedores a empresa busca uma relação de comprometimento, principalmente no que se refere aos prazos de entrega e qualidade dos produtos fornecidos.

É importante destacar que com os resultados obtidos na pesquisa aplicada aos fornecedores, ficou evidente que estes se sentem confortáveis com o tipo de relacionamento entre as partes, pois foram quase unânimes em demonstra seu contentamento. Este fato é muito relevante, pois significa que as políticas adotadas pela empresa são coerentes com a nova realidade, e ainda que a empresa caminha na direção certa, onde a busca em criar bases sólidas e sustentáveis nos relacionamentos se tornaram uma necessidade.

Com relação a seus colaboradores (funcionários), os resultados não foram tão satisfatórios quando se compara com os obtidos junto aos fornecedores, alguns grupos se mostraram insatisfeitos quanto ao relacionamento com a empresa, dentro destes grupos destacam-se o Primeiro Turno e os Mensalistas. De fato, constatou-se várias divergências destes grupos em relação as observações feitas pela própria empresa, situação esta que pode futuramente trazer problemas administrativos.

A situação que se apresenta entre as partes requer certa atenção, uma possível causa detectada é o momento vivido pela empresa que passa por reestruturações, criando assim um grande pacote de reformas estruturais importantes que poderão se configurar em novos conflitos a serem solucionados.

Outro aspecto observado é o fato da empresa ser bem menor que as outras pertencentes ao grupo, dificultando o acesso dos funcionários a promoções de cargos, propiciando uma quebra de perspectiva e desmotivação, um dos principais pontos a ser considerado numa gestão de relacionamento eficiente. É importante ressaltar que a empresa exerce a política de buscar preencher as vagas que surgem nos departamentos com funcionários internos, possibilitando a motivação destes, porém este volume é relativamente pequeno. Esta situação deve melhorar a partir do momento em que houver um crescimento significativo desta planta.

Pode-se afirmar que a empresa está buscando melhorar seu relacionamento com os funcionários, pois vem buscando estreitar este relacionamento transformando sua cultura e se aproximando de uma visão mais realista das mudanças das relações entre empregador e empregado. Um bom exemplo a ser citado é a criação pela empresa 
de uma comissão de representantes dos trabalhadores desta planta, que negocia todos os anseios e expectativa dos funcionários, esta ferramenta tem se mostrado um importante direcionador nas soluções de conflitos, consequentemente melhorando o relacionamento entre as partes.

É importante destacar que além do objetivo principal deste estudo, já destacado anteriormente, existem objetivos secundários de importância significativa que serão discutidos a seguir.

O relacionamento da empresa com seus fornecedores e funcionários pode ser considerado satisfatório, pois se baseiam em confiança, comprometimento e responsabilidade, pilares principais na construção de qualquer relacionamento duradouro.

O relacionamento da empresa com seus fornecedores é baseado em contratos formais o que propicia maior segurança para as partes. Graças a estes modelos, cada vez mais, a empresa tem formado parcerias de longo prazo, convergindo desta maneira para a formação de alianças estratégicas que proporcionam maior proteção a ambas as partes numa economia globalizada.

Outro aspecto importante a se considerar se refere a qualidade destes relacionamentos. Com relação aos fornecedores é bem satisfatória, a confiança na entrega e na qualidade dos produtos é mútua, já com relação aos funcionários a empresa não considera que estes se encontram totalmente envolvidos ou comprometidos dentro dos processos. É importante destacar que esta opinião é oposta a dos funcionários e que tal situação só poderá ser resolvida pela vontade da própria empresa.

Com relação as hipóteses que orientam o trabalho, pode-se afirmar que a empresa tem adotado algumas estratégias de aproveitamento de seu capital de relacionamento, mesmo que de uma maneira inconsciente, por exemplo, a formação de parcerias, alianças estratégicas e o melhor aproveitamento de seu capital intelectual. Esta situação ocorre porque a empresa possui condições estruturais e financeiras para o estabelecimento destas estratégias, além do respeito e confiabilidade que a marca proporciona.

Destaca-se que o enfoque principal para se atingir a excelência na gestão do capital de relacionamento está baseado na valorização dos elementos que o compõem, permitindo assim chegar a mais duas conclusões.

Para se trabalhar em um ambiente competitivo e aproveitar seu capital de relacionamento é extremamente importante a mudança da cultura organizacional da 
empresa. Fazendo com que as pessoas, acostumadas a trabalhar em sistemas altamente burocráticos e formais, passem a agir de forma mais racional e flexível, aproveitando desta maneira todo o potencial existente dentro e fora da organização.

Para uma organização alcançar a almejada vantagem competitiva é preciso praticar uma nova forma de mensurar os resultados obtidos, onde muito mais do que simplesmente ter uma boa eficiência, é preciso apresentar, também, um bom desempenho nos sete pontos identificados durante a construção do trabalho, que em essência são os elementos formadores do capital de relacionamento: conhecimento, comprometimento, relacionamento, custo, responsabilidade, informação e qualidade.

\subsection{TRABALHOS FUTUROS}

O presente estudo abre caminho para uma série de outras possibilidades de pesquisa:

- A aplicação do estudo com uma ênfase financeira, com o propósito de mostrar numericamente o retorno que a gestão deste capital fornece as organizações;

- A aplicação do estudo mais direcionado as relações humanas, com o propósito de evidenciar os principais obstáculos humanos na busca pela maior eficiência deste capital;

- A aplicação do estudo junto aos fornecedores com o propósito observar se estão se adaptando a nova realidade.

Como já mencionado, o leque que se abre para a elaboração de novos estudos é essencial para que cada vez mais se possa ter uma visão realista sobre as dificuldades e vantagens deste importante capital às organizações. Estas possibilidades de estudos que surgem são importantes, por isso vale destacar algumas das principais dificuldades encontradas na condução da pesquisa.

\subsection{LIMITAÇÕES DO ESTUDO}


Por ser um estudo de caso, baseado em apenas uma empresa do setor automobilístico, a pesquisa apresentou baixo poder de aplicação em um universo maior e não é um trabalho conclusivo.

Uma limitação inicial foi o acesso restrito do pesquisador, junto aos fornecedores da empresa pesquisada, principalmente pelo fato destes se encontrarem espalhados por diversas regiões do estado de São Paulo, esta situação diminuiu sensivelmente o número de participantes, pois todo contado foi realizado por meio eletrônico. Além disso, o pesquisador dependeu da honestidade dos entrevistados e da sua disposição em compartilhar suas opiniões.

O pouco número de executivos entrevistados na empresa também foi um fator limitador, pois o objetivo desta pesquisa era trabalhar com as opiniões de todos estes, porém isto não foi possível devido a problemas de agenda dos participantes.

Apesar dos cuidados metodológicos descritos, visando a imparcialidade na coleta de dados, a realização de entrevistas em profundidade as vezes está sujeita a vieses pessoais do entrevistado ou do entrevistador. 


\section{REFERÊNCIAS}

AGUIAR, E.C. (2002). Relações de fornecimento na indústria automobilística paranaense: o caso Chrysler e Dana. 180p. Dissertação (Mestrado) - Universidade Federal do Rio Grande do Sul, Porto Alegre. 2002.

ALVES FILHO, A.G. et al. (2000). Supply chaim assembler control: the case of Volkswagen's engine plant of São Carlos - SP - Brazil. In: RENCONTRE INTERNATIONALE DU GERPISA, 8, 2000, Paris.

ALVES FILHO, A.G. (2002). Assembler control of the supply chain: the case of an engine plant in Brazil. In: Acts du GERPISA Groupe d'Etudes et de Recherches Permanent Sur L 'Industries et les Salariés de L'Automobile. No. 33.

ANDRADE, E.P.; TOMAZ, L.G. (2003). Sinergia entre os capitais do conhecimento como forma de gestão: o caso Norway consultoria. 2.ed. Rio de Janeiro: Campus.

ANTUNES, M.T.P. (1999). Contribuição ao entendimento e mensuração do capital intelectual. 183p. Dissertação (Mestrado) - Faculdade de Economia, Administração e Contabilidade, Universidade de São Paulo, São Paulo. 1999.

ARGYRIS, C. (1992). Enfrentando defesas empresariais: facilitando o aprendizado. Rio de Janeiro: Campus.

BENSAOU, M. (1999). Portfolios of buger-supplier relationships. Sloan management review. Summer.

BERSON, A.; SMITH, S.; THERDING, K. (1999). Building data mining applications for CRM. McGraw Hill.

BITENCOURT, C. (2002). A liderança no contexto de uma organização de aprendizagem. Apresentado à Universidade Federal do Rio Grande do Sul, Porto Alegre, 2002.

BITENCOURT, C. (2004). A gestão de competências gerenciais e a contribuição da aprendizagem organizacional. Revista RAE, São Paulo, v.44, p.58-69, mar.

BOGMANN, I. M. (2002) Marketing de relacionamento: estratégias de fidelização e suas implicações financeiras. São Paulo: Nobel.

BONTIS, N. (2000). Assessing knowledge assets. A review of the models used to measure intellectual capital. Disponível em: <http://www.busines.queemsu.ca/Kbe/fp00-01.htm>. Acesso em jun. 2005.

BONTIS, N.; KEOW, W.C.C.; RICHARDSON, S. (2000). Intellectual capital and business performance in Malasysian industries. Journal of Intellectual Capital, Londres, v.1, n.1, p.85-100. 
BUCKINGHAM, M.; COFFMAN, C. (1999). First, break all the rules. What the world's reates managers do differently. Revista Você S.A., São Paulo, 1 out 2000, p.32.

CASSARÁ, C.A. (2003). Compartilhamento de informações e valorização dos indivíduos na empresa e seus reflexos na produtividade: um caso prático. 2.ed. Rio de Janeiro: Campus.

CAVALCANTI, M.; BALDAM, R.; VALLE, R. (2002). Gerenciamento eletrônico de dados. São Paulo: Érica.

CHAUI, M. (1999). Convite a filosofia. 12.ed. São Paulo: Ed. Ática.

CHEN, H.M.; LIN, K.J. (2000). The role of human capital cost in accounting. Journal of Intellectual Capital, Londres, v.1, n.1, p.85-100.

COBRA, M. (2001). Estratégias de marketing de serviços. São Paulo: Cobra.

COTRIM, G. (1989). Fundamentos da filosofia. 4.ed. São Paulo: Saraiva.

CUESTA, A. (2001). Learnig organization: Havana: ed universidad de la Havana.

DANVERPORT, T.; PRUSAK, L. (1998). Conhecimento empresarial: como as organizações gerenciam o seu capital intelectual. 3.ed. Rio de Janeiro: Campus.

DAVENPORT, T., PRUSAK, L. (1999). Conhecimento empresarial. Rio de Janeiro: Campus.

DAY, G.S.; REIBSTEIN, D.J. (1999). A dinâmica da estratégia competitiva. Rio de Janeiro: Campus .

DAZA, R.P. (2003). Gestão do conhecimento versus gestão das habilidades criativas nas organizações. Revista da Administração, São Paulo, v.38, n.1, p84-92, jan.

DRUCKER, P. (1999). Sociedade pós-capitalista. São Paulo: Ed. Pioneira.

DUGAN, M.S. (2000). CRM - recompensa com a lealdade do cliente. Anais eletrônicos... Disponível em: <http://www.computerman.com.br/artigos/art06.html>. Acesso em: 02 fev. 2006.

DURAND, A. (1998). Forms of incompetence. Apresentado na Conference of Management of Competence, Oslo, 1998.

EDVINSSON, L. (1992). How to value service organization. Aliança Sueca para o setor de serviços. Estocolmo, 1992.

EDVINSSON, L.; MALONE, M. S. (1998). Capital intelectual, descobrindo o valor real de sua empresa pela identificação de seus valores internos. Tradução de Roberto Galman. São Paulo: Ed. Makro book. 
FERREIRA, A.B.H. (1977). Minidicionário Aurélio. 1.ed. Rio de Janeiro: Ed. Nova Fronteira.

FIOL, C.M.; LYLES, M.A. (1985). Organizational learning. Academy of Management Review, v.10, p.803-13.

FLEURY, A.; FLEURY, M.T.L. (1995). Aprendizagem e inovação organizacional. As experiências de Japão, Coréia. São Paulo: Atlas.

FLEURY, M.T.L. (1997). O desvendar e transformação de uma organização - uma discussão metodológica, in FLEURY, Maria Tereza Leme e FISCHER, Rosa Maria (coord.) - cultura e poder nas organizações. São Paulo: Atlas.

FLEURY, A.; FLEURY, M.T.L. (2001). Estratégias empresarias e formação de competências. Um quebra-cabeça caleidoscópico da indústria brasileira. São Paulo: Atlas.

FLEURY, A.; FLEURY, M.T.L. (2004). Alinhando estratégia e competência. Revista $R A E$, São Paulo, v.44, p.44-57, mar.

GARVIN, D.A. (1993). Building a learning organization. Harvard Business Review, p.78-91, mar/aug.

GIL, A.C. (1996). Como elaborar projetos de pesquisa. São Paulo: Atlas.

GILBERT, M.; LEIBOLD, M.; VOELPEL, S. (2001). Rejuvenating corporate intellectual capital by co-opting customer competence. Journal of Intellectual Capital, Londres, v.2, n.2, p.109-126.

GRIFFIN, J. (1998). Como conquistar e manter o cliente fiel: transforme seus clientes em verdadeiros parceiros. São Paulo: Futura.

HAIR, J. et. Al. (2005). Fundamentos de métodos de pesquisa em administração. Porto Alegre: Bookman.

HAMEL, G.; PRAHALAD, C. (1995). Competindo pelo futuro: estratégias inovadoras para obter o controle do seu setor e criar os mercados de amanhã. 10.ed. Rio de Janeiro: Campus.

HAMEL, G.; PRAHALAD, C.K. (1995). Competindo pelo futuro. Rio de janeiro: Campus.

HAMMER, M. (1997). A agenda. Rio de Janeiro: Campus.

KANTER, R.M. (1989). Whengiants learn todance. Routledge. 1989.

KAPLAN, R.S.; NORTON, D.P. (1995). The Balanced Scorecard. Harvard Business Review, Londres, 1995. 
KENNEDY, F. (1998). Literature review intellectual capital in valuing intangible assets. Journal of Intellectual Capital, Londres, v.4, n.4, p.121-137.

KOTLER, P.; ARMSTRONG, G. (1995). Princípios de marketing. 5.ed. Rio de Janeiro: LTC.

KOTLER, P. (1997). Administração de marketing: análise, planejamento, implantação e controle. 4.ed. São Paulo: Atlas.

KRUGLIANSKAS, I.; TERRA, J.C. (2003). Gestão do conhecimento em pequenas e médias empresas. 2.ed. Rio de Janeiro: Campus.

LAINO, A. (2004). Cultura Organizacional e gestão de pessoas: um estudo de caso em academias de ginástica. 234p. Dissertação (Mestrado) - Universidade Federal Fluminense, Niterói. 2004.

LAKATOS, E.M.; MARCONI, M. (2000). Metodologia cientifica. 3.ed. São Paulo: Atlas.

LAMMING, R. (1993). Beyond partnership: strategies for innovation and lean supply. Prantice-hall.

LIMA, J.C.S. (2004). Um estudo sobre a reconfiguração da função de compras em empresas do setor automotivo. 184p. Tese (Doutorado) - Escola Politécnica, Universidade de São Paulo, São Paulo. 2004.

MCKENNA, R. (1996). Marketing de relacionamento: estratégias bens sucedidas para a era do cliente. Rio de Janeiro: Campus.

MCKENNA, R. (1999). Estratégia de marketing em tempos de crise. Tradução de Elizabeth Maria de Pinho Braga. Rio de Janeiro: Campos; São Paulo: Publifolha.

MATHEUS, L.F. (2003). Uma análise da identificação e da gestão do capital intelectual nas usinas sucroalcooleiras e da prática dos princípios delineadores do conceito de avaliação de empresas na sua gestão econômica financeira: um estudo exploratório. 174p. Dissertação (Mestrado) - Escola de Engenharia de São Carlos, Universidade de São Paulo, São Carlos. 2003.

MATTAR, F.N. (1994). Pesquisa de marketing. São Paulo: Atlas.

MICHAEL, E.; KOENIG. D. (2000). Intellectual capital and how to leverage it. Journal of Intellectual Capital, Londres, v.1, n.1, p.22-33.

MICHAELIS, D. (1996). Pequeno dicionário Michaelis. São Paulo: Ed. Melhoramentos.

MORGAM, R.; HUNT, S. D. (1994). The conmitment-trust theory of relationship. Journal of Marketing, [S.I.], v. 58, p.20-38, jul. 
MOURA, L.R. (1999). Gestão integrada da informação: proposição de um modelo de organização baseado no uso da informação como recurso da gestão empresarial. Apresentado à Escola Politécnica da Universidade de São Paulo, São Paulo, 1999.

NERDRUM, L (2000). A human capital perspective. Journal of Intellectual Capital, Londres, v.1, n.2.

NEWLL, F. (2000). Fidelidade.com. Tradução de Maria Lucia G. L. Rosa. São Paulo: Makron Books.

NONATA, I.; TAKEUCHI, H. (1997). Criação de conhecimento na empresa. Rio de Janeiro: Campus.

OLIVEIRA, S.L. (2001). Tratado de metodologia cientifica. São Paulo: Ed. Pioneira.

ORSI, A. (2003). Incorporação de bases externas de conhecimento a gestão do conhecimento nas fusões e aquisições de empresas. 137p. Dissertação (Mestrado) Faculdade de Economia, Administração e Contabilidade, Universidade de São Paulo, São Paulo. 2003.

PEPPERS, P.; ROGERS, M. (1999). One to one manager: real-worlds lersons in customer relationship management. Newwork: Currency/Doubleday.

PERROTTI, E. (2004). Estrutura organizacional e gestão do conhecimento. 206p. Dissertação (Mestrado) - Faculdade de Economia, Administração e Contabilidade, Universidade de São Paulo, São Paulo. 2004.

PETTY, R.; GUTHRIE, J. (2000). Intellectual capital literature review measurement. Reporting and Management, Londres, v.1, n.2, p.155-176.

PIMENTEL, A.C. (2003). Adaptação de uma proposta de sistemas de gestão de conhecimento para empresas. Apresentado à UNESP, Bauru, 2003.

PIMENTEL, A.C.; ALBINO, J. (2003). Dificuldades na aplicação de gerenciamento de conhecimento $(K M)$ em empresas brasileiras de médio porte. Apresentado ao $\mathrm{X}$ SIMPEP, Bauru, 2003.

POLANYI, M. (1983). Personal knowedgle: Twards a Past-Critical Philosophy. Londres, 1983.

POSTHUMA, A.C. (1997). Autopeças na encruzilhada: modernização desarticulada e desnacionalização. In: ARBIX, G., ZILBOVICIUS, M. (orgs). De JK a FHC: $a$ reinvenção dos carros. São Paulo: Scritta.

RIBEIRO, M.C. (2005). Atendimento ao cliente como diferencial. 86p. Monografia (Pós-Graduação) - Universidade Central Paulista, São Carlos. 2005.

ROBBINS, S.P. (2000). Mudanças e Perspectivas. Tradução de Cid Knipel Moreira. São Paulo: Saraiva. 
ROBBINS, S. (2002). Comportamento Organizacional. São Paulo: Prentice Hall.

ROBERTI, R. (2001). Consórcio modular de Resende. 83p. Monografia (Graduação) Universidade Central Paulista, São Carlos, 2001.

ROBLES, L.T. (2001). A prestação de serviços de logística na indústria automobilística no Brasil: em busca de alianças estratégicas. 188p. Tese (Doutorado) Faculdade de Economia, Administração e Contabilidade, Universidade de São Paulo, São Paulo. 2001.

RODRIGUES, H.T.; ANTUNES, A.M.S.; DUTRA, L.E.D. (2003). Análise de proposta de modelos de gestão direcionados para o conhecimento. Revista ADM, São Paulo, v.38, n.1, p.66-76, mar.

RODRIGUES, S.B.; CHILD, J.; LUZ, T.R. (2004). Aprendizagem contestada em ambiente de mudança radical. Revista RAE, São Paulo, v.44, p.27-41, mar.

RODRIGUEZ, M.V.R.Y. (2002). Gestão empresarial: organizações que aprendem. Rio de Janeiro: Qualitymark.

SALERNO, M.S. (1998). Mudanças e persistências no padrão de relações entre montadoras e autopeças no Brasil. Revista de Administração, São Paulo, v.33, n.3, p.1628 , jul/set.

SALERMO, M.S.; MARX, R.; ZILBOVICIUS, M. (2003).A nova configuração da cadeia de fornecimento na indústria automobilística do Brasil. Revista Administração da USP, São Paulo, v. 38, n. 3, p.192-204.

SANTIAGO JUNIOR, J.R.S. (2002). O desenvolvimento de uma metodologia para gestão do conhecimento em uma empresa de construção civil. 192p. Dissertação (Mestrado) - Escola Politécnica, Universidade de São Paulo, São Paulo. 2002.

SANTOS, A.C. (2001). Learnig organization. Havana: Ed. Universidade de La Havana.

SANTOS, A.C. (2003). Gestão do conhecimento da organização que aprende e de competências: a era digital. Revista ADM, São Paulo, v.38, n.1, p.38-48, mar.

SEBRAE: banco de dados. (2001). Disponível em: <http://www.sebrae.org.com.br>. Acesso em 20 set.

SENGE, P. (1990). A quinta disciplina. São Paulo: Best seller.

SHEIN, E. (1986). Organizational culture end leodership. San Francisco: Jossey-bass.

SHETH, J.; PARVATIYAR, A. (2000). Handbook of relationship marketing. London: Sage Publications Inc.

SHINGO, S. (1997). Controle de qualidade, inspeção de defeitos e o sistema de PokaYoke. São Paulo: Imprensa de produtividade. 
SILVA FILHO, Z.; MONTEIRO JUNIOR, A. (2004). A utilização da ferramenta CRM (costumer relationship management) como vantagem competitiva no varejo - um estudo exploratório com representantes comerciais. In: SIMPÓSIO DE ENGENHARIA DE PRODUÇÃO, 11., 2004, Bauru. Anais eletrônicos... Bauru: UNESP. Disponível em: <http://www.feb.unesp.br/dep/simpep/todos.html>. Acesso em: 23 jan. 2006.

SILVA, C.D.F.; NAGANO, M.S. (2005). O capital de relacionamento como estratégia de qualidade. Apresentado XII SIMPEP, Bauru, 2005.

SLACK, N. et al. (1997). Administração da Produção. São Paulo: Atlas.

SOLTERO, A.P. (2003). Gestão do conhecimento na solução de problema de gestão de qualidade. Rio de Janeiro: Negócio.

SOUZA, M.P. (2004). Gestão dos elos da cadeia de valor de porter aplicado as relações entre empresas e as organizações do terceiro setor: um ensaio. In: SIMPÓSIO DE ENGENHARIA DE PRODUÇÃO, 11., 2004, Bauru. Anais eletrônicos... Bauru: UNESP. Disponível em: <http://www.feb.unesp.br/dep/simpep/todos.html>. Acesso em: 23 jan. 2006.

STEWART, T.A (1998). Capital intelectual. 6.ed. Rio de Janeiro: Campus.

SULLIVAN, P.H. (1999). Profiting from intellectual capital Journal of Knowledge Management, Londres, v.3, n.2, p.132-142.

SVEIBY, K.E. (1998). A nova riqueza das organizações. Gerenciando e avaliando patrimônios de conhecimento. São Paulo: Campus.

TERRA, J.C. (1999). Gestão do conhecimento: aspectos conceituais e estudo exploratório sobre as práticas de empresas brasileiras. 172p. Tese (Doutorado) POLI, Universidade de São Paulo, São Paulo. 1999.

TERRA, J.C. (2001). Gestão do conhecimento o grande desafio empresarial. 2.ed. São Paulo: Negócio.

TERRA, J.C. (2003). Gestão do conhecimento e-learning na prática. Rio de Janeiro: Elsevier.

THUROW, L. (2001). A construção da riqueza. Rio de Janeiro: Rocco.

TOFFlER, A. (1988). A terceira onda. Tradução de João Távora. 23.ed. Rio de Janeiro: Record.

TUNDISI, J. G. (2003). Água no século XXI: enfrentado a escassez. São Carlos: Rima.

VIDAL, A. G. (1993). Frutos do passado sementes do futuro. São Paulo: Érica.

VOLKSWAGEN: banco de dados. (2005). Disponível em: $<$ http://intranet.volkswagen.com.br>. Acesso em: 13 mar. 
WRIGHT, P.; KROLL, M.J.; PARNELL, J. (2000). Administração estratégica e conceitos. São Paulo: Atlas.

YIN, R.K. (1994). Case study research: design and methods. 2.ed. Thousand Oaks, USA: Sage.

ZAWISLAK, P.A. (2001). Economia das organizações é a base para o pensamento estratégico. In: CLEGG, S.; HARDY, C.; NAD, W. (orgs). Handbook de estudos organizacionais. São Paulo: Atlas. p.25-36. 


\section{APÊNDICE A - Questionário: funcionários Fábrica de Motores São Carlos}

\begin{tabular}{|c|c|c|}
\hline SETOR & $\begin{array}{l}\text { ( ) USINAGEM } \\
\text { ( ) MONTAGEM /RUMPF } \\
\text { ( ) QUALIDADE } \\
\text { ( ) EA113 } \\
\text { ( ) FERRAMENTARIA } \\
\text { ( ) MANUTENÇÃO/RUMPF } \\
\text { ( ) MANUTENÇÃO/ZP4 } \\
\text { ( ) MANUTENÇÃO/USINAGEM }\end{array}$ & $\begin{array}{l}\text { ( ) ENGENHARIA } \\
\text { ( ) MONTAGEM /ZP4 } \\
\text { ( ) LOGISTICA } \\
\text { ( ) UTILIDADES } \\
\text { ( ) RH } \\
\text { ( ) FINANCEIRO } \\
\text { ( ) ETE } \\
\text { ( ) OUTROS }\end{array}$ \\
\hline $\begin{array}{l}\text { TEMPO DE } \\
\text { EMPRESA }\end{array}$ & $\begin{array}{l}\text { ( ) MENOS DE } 1 \text { ANO } \\
\text { ( ) DE } 3,1 \text { A } 5 \text { ANOS } \\
\text { ( ) DE } 7,1 \text { A } 10 \text { ANOS }\end{array}$ & $\begin{array}{l}\text { ( ) DE 1,1 A } 3 \text { ANOS } \\
\text { ( ) DE 5,1 A } 7 \text { ANOS } \\
\text { ( ) MAIS DE } 10 \text { ANOS }\end{array}$ \\
\hline ESCOLARIDADE & $\begin{array}{l}\text { ( ) } 2 \text { GRAU COMPLETO } \\
\text { ( ) } 3 \text { GRAU INCOMPLETO } \\
\text { ( ) PÓS GRADUAÇÃO INCOMPLETA }\end{array}$ & $\begin{array}{l}\text { ( ) } 3 \text { GRAU COMPLETO } \\
\text { ( ) PÓS GRADUAÇÃO COMPLETA }\end{array}$ \\
\hline $\begin{array}{l}\text { TURNO DE } \\
\text { TRABALHO }\end{array}$ & ( ) 1 TURNO & ( ) MENSALISTA \\
\hline
\end{tabular}

As respostas são de caráter alternativo, e o responsável pelas informações deverá optar somente por uma alternativa relacionada a cada resposta, que iniciam-se de discordo fortemente até o concordo fortemente. É importante destacar que o objetivo deste estudo é estritamente acadêmico, e as respostas obtidas nele serão tratadas com total sigilo.

\begin{tabular}{|c|l}
\hline 1 & Sua empresa atende todas suas expectativas profissionais? \\
\hline
\end{tabular}

Exemplo:

\section{Questões}

\begin{tabular}{|l|l|l|l|l|l|l|}
\hline 1 & 2 & 0 & 4 & 5 & 6 & 7 \\
\hline
\end{tabular}

\begin{tabular}{|c|c|c|c|c|c|c|c|}
\hline \multicolumn{2}{|c|}{ Questões } & \multicolumn{3}{|c|}{$\begin{array}{l}\text { Discordo } \\
\text { Fortemente }\end{array}$} & \multicolumn{3}{|c|}{$\begin{array}{l}\text { Concordo } \\
\text { fortemente }\end{array}$} \\
\hline $\mathrm{A}-$ & - Funcionários & \begin{tabular}{l|l|l|l}
1 & 2 &
\end{tabular} & \begin{tabular}{l|l}
2 & 3
\end{tabular} & \begin{tabular}{l|l}
3 & 4
\end{tabular} & & 6 & 7 \\
\hline 1 & $\begin{array}{l}\text { A empresa estimula uma cultura de aprendizagem, criação e compartilhamento do } \\
\text { conhecimento? }\end{array}$ & & & & & & \\
\hline 2 & $\begin{array}{l}\text { A empresa utiliza-se de ferramentas para facilitar o processo de geração e disseminação do } \\
\text { conhecimento? }\end{array}$ & & & & & & \\
\hline 3 & Você colabora com a empresa em eventuais necessidades? & & & & & & \\
\hline 4 & $\begin{array}{l}\text { Você é estimulado a alertar a empresa sobre os problemas existentes durante o processo } \\
\text { produtivo? }\end{array}$ & & & & & & \\
\hline 5 & O seu relacionamento com os outros setores da empresa é satisfatório? & & & & & & \\
\hline 6 & A empresa fornece treinamentos adequados com relação à fabricação de novos motores? & & & & & & \\
\hline 7 & A política de redução de custos da empresa tem se mostrado eficiente? & & & & & & \\
\hline 8 & A empresa se preocupa com a sua integridade e saúde? & & & & & & \\
\hline 9 & A responsabilidade de eventuais falhas no processo é compartilhada? & & & & & & \\
\hline 10 & $\begin{array}{l}\text { A empresa entrega seus motores dentro dos prazos estabelecidos às plantas do grupo } \\
\text { (Anchieta, Buc, Taub, etc.)? }\end{array}$ & & & & & & \\
\hline 11 & A empresa comunica suas estratégias e resultados a você? & & & & & & \\
\hline 12 & A empresa comunica de forma clara suas exp ectativas sobre você? & & & & & & \\
\hline 13 & As ferramentas utilizadas pela empresa para sua informação são eficientes? & & & & & & \\
\hline 14 & A empresa possui uma boa imagem no mercado? & & & & & & \\
\hline 15 & As peças recebidas na empresa possuem certificados de qualidade de seus fornecedores? & & & & & & \\
\hline 16 & Nos últimos anos os indicadores de qualidade da empresa melhoraram? & & & & & & \\
\hline 17 & $\begin{array}{l}\text { A média salarial aplicada pela empresa, em relação a sua função, está acima da média paga } \\
\text { pela região? }\end{array}$ & & & & & & \\
\hline 18 & A empresa reconhece os serviços prestados por você? & & & & & & \\
\hline 19 & A marca da empresa é respeitada no mercado? & & & & & & \\
\hline
\end{tabular}




\section{APÊNDICE B - Questionário: Fornecedores Fábrica de Motores São}

\section{Carlos}

\begin{tabular}{|l|l|}
\hline EMPRESA & \\
\hline SETOR DE ATUAÇÃO & \\
\hline PAÍS DE ORIGEM & \\
\hline TEMPO DE CONSTITUIÇÃO & \\
\hline TEMPO NO BRASIL & \\
\hline TEMPO DE PARCERIA & \\
\hline ENTREVISTADO $($ NOME) & \\
\hline CARGO & \\
\hline TEMPO DE EMPRESA & \\
\hline ESCOLARIDADE & \\
\hline TELEFONE & \\
\hline E-MAIL & \\
\hline
\end{tabular}

Os termos parceiro e cliente, utilizados nas questões dizem respeito a Fábrica de Motores São Carlos, objeto de estudo neste trabalho. As respostas são de caráter alternativo, onde o responsável pelas informações deverá optar por somente uma alternativa relacionada a cada resposta, iniciando-se do discordo fortemente até o concordo fortemente. É importante destacar que o objetivo deste estudo é estritamente acadêmico, e as respostas obtidas serão tratadas com total sigilo.

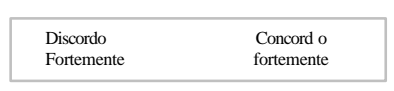

Exemplo:

\begin{tabular}{|c|l|l|l|l|l|l|l|l|}
\hline 1 & Sua empresa atende a todas suas expectativas profissionais? & 1 & 2 & 0 & 4 & 5 & 6 & 7 \\
\hline
\end{tabular}

\section{Questões}

Discordo

Concordo

Fortemente fortemente

\begin{tabular}{|c|c|c|c|c|c|c|c|c|}
\hline \multicolumn{2}{|c|}{ A - Fornecedores } & 1 & 2 & 3 & 4 & 5 & 6 & 7 \\
\hline 1 & $\begin{array}{l}\text { Seu cliente estimula uma cultura de aprendizagem, criação e compartilhamento do } \\
\text { conhecimento com você? }\end{array}$ & & & & & & & \\
\hline 2 & $\begin{array}{l}\text { Seu cliente utiliza-se de ferramentas para facilitar o processo de geração e disseminação do } \\
\text { conhecimento com você? }\end{array}$ & & & & & & & \\
\hline 3 & $\begin{array}{l}\text { Você colabora com seu cliente em eventuais necessidades (Ex: fornecimento maior de } \\
\text { produtos)? }\end{array}$ & & & & & & & \\
\hline 4 & $\begin{array}{l}\text { Você é estimulado a alertar seu cliente sobre possíveis problemas existentes nos seus } \\
\text { produtos? }\end{array}$ & & & & & & & \\
\hline 5 & O relacionamento da empresa com seu cliente é satisfatório? & & & & & & & \\
\hline 6 & $\begin{array}{l}\text { Os custos de desenvolvimento de novos produtos são repassados ou compartilhados com seu } \\
\text { cliente? }\end{array}$ & & & & & & & \\
\hline 7 & A empresa fornece treinamentos com relação à fabricação de novos produtos a seu cliente? & & & & & & & \\
\hline 8 & $\begin{array}{l}\text { A responsabilidade de eventuais falhas no processo é compartilhada entre a empresa e o } \\
\text { cliente? }\end{array}$ & & & & & & & \\
\hline 9 & A empresa entrega seus produtos dentro dos prazos estabelecidos a seu cliente? & & & & & & & \\
\hline 10 & Seu cliente comunica sua estratégia e resultados a você? & & & & & & & \\
\hline 11 & Seu cliente comunica de forma clara suas expectativas sobre a parceria com você? & & & & & & & \\
\hline 12 & A empresa é comprometida com a qualidade dos produtos fornecidos a seu cliente? & & & & & & & \\
\hline 13 & Seu cliente exige certificados de qualidade? & & & & & & & \\
\hline 14 & Seus indicadores de qualidade melhoraram com o desenvolvimento da parceria? & & & & & & & \\
\hline 15 & Seu cliente possui uma boa imagem no mercado? & & & & & & & \\
\hline 16 & A marca do seu cliente é respeitada no mercado? & & & & & & & \\
\hline 17 & Na busca de novos projetos seu cliente procura, na maioria das vezes, você? & & & & & & & \\
\hline 18 & Seu cliente compra uma cota mínima de produtos mensais de você? & & & & & & & \\
\hline 19 & Seu cliente reconhece os serviços prestados por você? & & & & & & & \\
\hline 20 & As transações com seu cliente são realizadas através de contratos formais? & & & & & & & \\
\hline
\end{tabular}




\section{APÊNDICE C - Roteiro de entrevista - executivos da Fábrica de Motores}

São Carlos

\section{COLETA DE DADOS}

\begin{tabular}{|l|l|}
\hline ENTREVISTADO & \\
\hline CARGO & \\
\hline TEMPO DE EMPRESA & \\
\hline NIVEL DE ESCOLARIDADE & \\
\hline TELEFONE & \\
\hline E-MAIL & \\
\hline
\end{tabular}

\section{Conhecimento}

1. A empresa estimula uma cultura de aprendizagem, criação ou compartilhamento do conhecimento, com seus funcionários e fornecedores? Como esta foi constituída?

2. A empresa utiliza-se de ferramentas para facilitar o processo de geração e disseminação do conhecimento com seus funcionários e fornecedores? Quais?

\section{Comprometimento}

1. A empresa conta com a colaboração de seus funcionários e fornecedores em eventuais necessidades, tais como horas extras, etc.?

2. A empresa conta com a colaboração de seus funcionários e fornecedores para o alerta de eventuais problemas durante o processo produtivo e qualidade dos produtos?

\section{Relacionamento}

1. Como você considera o relacionamento da empresa com seus funcionários e fornecedores?

2. O relacionamento entre os setores da empresa está dentro das expectativas?

3. A média salarial aplicada pela empresa está acima da média paga pelo mercado?

4. A empresa reconhece os serviços prestados por seus funcionários e fornecedores? De que forma esse reconhecimento é transmitido?

5. A empresa adquire uma cota mínima de produtos de seus fornecedores?

6. Na busca de novos projetos a empresa procura, na maioria das vezes, seus fornecedores já conhecidos? Por quê?

7. A empresa procura realizar as transações com seus fornecedores através de contratos formais?

\section{Custos}

1. Na eventualidade de fabricação de novos produtos a empresa oferece treinamentos adequados aos seus funcionários e fornecedores?

2. A empresa utiliza alguma política de redução de custos? Qual? Ela tem se mostrado eficiente?

3. Os custos de desenvolvimento de novos produtos são repassados ou compartilhados com seus fornecedores? 


\section{Responsabilidade}

1. A responsabilidade de eventuais falhas no processo é compartilhada por todos os envolvidos (funcionários e fornecedores)?

2. A empresa entrega seus produtos dentro dos prazos estabelecidos às plantas da organização?

3. A empresa se preocupa com a integridade e saúde de seus funcionários? De que forma?

\section{Informação}

1. A empresa comunica suas estratégias e resultados aos funcionários e fornecedores? Como?

2. A empresa comunica de forma clara suas expectativas sobres seus funcionários e fornecedores?

3. As ferramentas utilizadas pela empresa para informar funcionários e fornecedores são eficientes? Quais são?

\section{Qualidade}

1. As peças recebidas na empresa possuem certificados de qualidade de seus fornecedores?

2. Nos últimos anos os indicadores de qualidade da empresa melhoraram? Por quais motivos?

\section{Imagem}

1. A marca da empresa é respeitada no mercado?

2. A empresa possui uma boa imagem no mercado?

3. As parcerias formadas pela empresa têm se mostrado importante no mercado? 


\section{Entrevista com RH}

\section{Conhecimento}

3. A empresa estimula uma cultura de aprendizagem, criação ou compartilhamento do conhecimento com seus funcionários e fornecedores? Como esta foi constituída?

R: Sim, a empresa estimula e promove a criação e compartilhamento do conhecimento com seus funcionários e fornecedores, através de varias ferramentas utilizadas pelo grupo Volkswagen.

- A base deste conhecimento acontece principalmente por um sistema de informações interligadas entre todas as unidades da Organização, que compartilham experiências e idéias entre si, criando desta maneira uma memória organizacional, disponível a todos.

Obs.: Um dos problemas enfrentado está relacionado diretamente ao idioma não dominado por todos dentro da organização, tendo em vista a enormidade do grupo presente em vários países com línguas diferentes e também a empresa ainda não utiliza o seu potencial, ou seja, todo o conhecimento disponível, desta forma ainda à espaço para melhorias.

4. A empresa utiliza-se de ferramentas para facilitar o processo de geração e disseminação do conhecimento com seus funcionários e fornecedores? Quais?

R: Sim, a empresa utiliza-se de várias ferramentas neste sentido.

- O programa de geração de idéia é um bom exemplo onde o funcionário é estimulado a fornecer sugestões de melhoria dentro da organização. Fornecendo desta maneira material para a criação de um banco de dados virtual onde todos do grupo possuem acesso as melhores práticas desenvolvidas para se melhorar o produto ou indicadores.

Obs.: Os fornecedores também são incentivados a participar deste processo, são linkados através dos sistemas de informações.

\section{Comprometimento}

3. A empresa conta com a colaboração de seus funcionários e fornecedores em eventuais necessidades, tais como horas extras, etc.?

R: Em relação aos funcionários mais ou menos não existe uma unanimidade neste sentido, já que a colaboração destes não é algo tão espontâneo como se gostaria, porém um grupo significativo de pessoas está sempre pré-dispostos a auxiliar a empresa neste sentido. É importante destacar que existe a possibilidade de se melhorar esta situação, e por isso a empresa está buscando dentro do possível revertê-la.

- Em relação aos fornecedores existe uma flexibilidade bem maior, ou seja, não existem problemas significativos.

\section{A empresa conta com a colaboração de seus funcionários e fornecedores para o alerta de eventuais problemas durante o processo produtivo e qualidade dos produtos?}

R: A empresa conta com a colaboração dos funcionários, neste sentido existe um grupo de técnicos responsáveis por analisarem problemas existentes, e ainda buscar meios para solucioná-los, uma das ferramentas mais utilizadas é um sistema 
conhecido como Poka-Yoke, que possui o objetivo de auxiliar os func ionários em processo que eventualmente poderiam ocorrer falhas. Destaca-se também que a empresa busca incentivar este alerta por parte dos funcionários evitando que os erros passem para frente o que pode acarretar em prejuízos maiores.

- A empresa também conta com a colaboração dos fornecedores, embora exista a necessidade de se melhorar a qualidade do produto.

\section{Relacionamento}

8. Como você considera o relacionamento da empresa com seus funcionários e fornecedores?

$\mathrm{R}$ : O relacionamento com os funcionários precisa ser melhorado.

Com relação aos fornecedores este relacionamento é satisfatório, pois a empresa tem procurado formar parcerias e alianças estratégicas desta forma melhorando e estreitando os laços entre as empresas.

9. O relacionamento entre os setores da empresa está dentro das expectativas?

R: Pode-se afirmar que ouve progresso, porém existe a necessidade de se melhorar a sinergia entre os departamentos.

10. A média salarial aplicada pela empresa está acima da média paga pelo mercado?

R: Sim, a média salarial aplicada pela empresa está acima do mercado. Também é importante destacar que a empresa realiza pesquisas locais com concorrentes do mesmo tipo de produto, autopeças e montadoras.

11. A empresa reconhece os serviços prestados por seus funcionários e fornecedores? De que forma esse reconhecimento é transmitido?

R: Sim, com relação aos funcionários a empresa possui ferramentas formais de reconhecimento, como o sistema de avaliação de desempenho e o programa de geração de idéias, onde se realiza um evento comemorativo aos funcionários que destacaram durante o ano anterior.

Com relação aos fornecedores também sim, existe um evento de reconhecimento anual para premiar os melhores fornecedores do ano anterior, aqueles que mantiveram seus índices de qualidade ou melhoraram e ainda os que entregaram seus produtos no prazo estabelecidos pela companhia.

12. A empresa adquire uma cota mínima de produtos de seus fornecedores?

R: Existe um volume mensal acordado com os fornecedores, porém para um maior esclarecimento consultar o responsável desta área, Sr. Rita.

13. Na busca de novos projetos a empresa procura, na maioria das vezes, seus fornecedores já conhecidos? Por quê?

R: Com certeza, por conta da relação de parceria estabelecida, que conseqüentemente reduzem custos em novos projetos, já que os parceiros conhecem o produto e os padrões da companhia.

\section{A empresa procura realizar as transações com seus fornecedores através de} contratos formais?

R: Sempre, pois são relações comercias que exigem contratos formalizados com a garantia para ambas as partes. 


\section{Custos}

4. Na eventualidade de fabricação de novos produtos a empresa oferece treinamentos adequados aos seus funcionários e fornecedores?

R: A idéia da empresa é fornecer treinamento sempre que necessário tanto para os funcionário como para os fornecedores. Para os funcionários existe um sistema conhecido como on the job que faz que estes trabalhem por toda a extensão de suas linhas, não ficando este somente em único posto como no passado, isto acaba familiarizando o empregado com todos os processos de montagens necessários para se produzir um motor. Já para os fornecedores a empresa fornece seu produto acabado para que este analise os resultados de seus componentes dentro dos motores.

\section{A empresa utiliza alguma política de redução de custos? Qual? Ela tem se mostrado eficiente?}

R: A empresa utiliza-se de uma política de redução de custos permanentes, redução esta que passa por todos os insumos utilizados no processo de produção (água, luz, pessoas, etc.). E esta política tem se mostrado eficiente em relação ao cumprimento de seus objetivos, porém a empresa destaca que por causa da desvalorização do dólar frente ao real ela não conseguiu fechar no azul no ano de 2005.

\section{Os custos de desenvolvimento de novos produtos são repassados ou compartilhados com seus fornecedores?}

R: São, porém cada fornecedor é tratado diferentemente levando-se em consideração principalmente o tipo de contrato firmado com este e a área de compras corporativas da organização (Anchieta). Estes contratos são extensos e detalhados, mesmo sendo corporativos a planta de São Carlos pode exigir algumas premissas como qualidade, tempo de entrega, etc.

\section{Responsabilidade}

4. A responsabilidade de eventuais falhas no processo é compartilhada por todos os envolvidos (funcionários e fornecedores)?

$\mathrm{R}$ : Se as falhas forem do processo de produção o problema é da empresa, que busca esclarecer o problema internamente utilizando-se da estrutura hierárquica existente (lideres, monitores e auditores), que procuram rastrear os problemas e orientar as pessoas envolvidas nele sem punições.

Os fornecedores também são tratados quase da mesma maneira, a diferença se dá que se for um problema causado por estes as eventuais perdas serão debitados destes.

\section{A empresa entrega seus produtos dentro dos prazos estabelecidos às plantas} da organização?

R: Sim.

6. A empresa se preocupa com a integridade e saúde de seus funcionários? De que forma?

R: Sim. A empresa fornecer equipamentos de seguranças (EPI), a empresa adequa postos de trabalhos as necessidades dos funcionários, faz auditorias de seguranças permanentes, realiza a semana de prevenção de acidentes com ilustrações e peças de teatros. E, caso haja necessidade, conversa diretamente com os empregados 
envolvendo-os numa mudança de hábitos mais seguros e conscientes. E ainda cria palestra sobre problemas relacionados a saúde fora da empresa que possam comprometer a integridade dos funcionários (AIDS, DENGUE).

\section{Informação}

4. A empresa comunica suas estratégias e resultados aos funcionários e fornecedores? Como?

R: Sim. Aos funcionários de uma forma mais ampla semestralmente através dos quadros de aviso, reuniões de trabalhos e jornal da companhia. Já para os fornecedores através dos planos de produção e contatos diários.

5. A empresa comunica de forma clara suas expectativas sobres seus funcionários e fornecedores?

R: Sempre, utilizando-se das ferramentas citadas acima, a empresa lembra seus funcionários que ela os pagas para que estes cumpram com seus deveres. A um processo de comunicação claro.

Com relação aos fornecedores, idem.

6. As ferramentas utilizadas pela empresa para informar funcionários e fornecedores são eficientes? Quais são?

R: Sim. A empresa utiliza-se da liderança, gerência de fábrica, quadros de aviso, sistema oito passos, jornal, rádio peão e sindicato para informação dos funcionários.

Com relação aos fornecedores o processo de informação é associado diretamente ao cliente, a produção, qualidade e a logísticas estão interligadas simultaneamente.

\section{Qualidade}

3. As peças recebidas na empresa possue m certificados de qualidade de seus fornecedores?

R: Adilsom?

4. Nos últimos anos os indicadores de qualidade da empresa melhoraram? Por quais motivos?

R: Sim, principalmente por conta do conhecimento dos empregados, adoção de novas medidas de contenção, a melhora dos processos produtivos dos fornecedores, e uma divulgação da cultura voltada para a qualidade dos produtos.

\section{Imagem}

4. A marca da empresa é respeitada no mercado?

R: Sem dúvida, recentemente a empresa foi avaliada pela Top of mid, como a primeira montadora de veículos na mente dos consumidores.

5. A empresa possui uma boa imagem no mercado?

R: Sem dúvida, a marca está associada à confiança, baixa manutenção e segurança dos produtos.

6. As parcerias formadas pela empresa têm se mostrado importante no mercado? 
R: Sim, com certeza. Estamos na posição que estamos graças também as parcerias formadas pela empresa. Parcerias de sucesso como o caso do Total Flex desenvolvido em conjunto com a Bosch do Brasil.

7. Considerações finais ou observações do entrevistado?

$\mathrm{R}$ : Sem considerações finais.

Data: 21 / 02 / 2006

Hora início: 11 / 35 / 00

Hora término: 12 / 26 / 00 


\section{Entrevista com a Qualidade}

\section{Conhecimento}

5. A empresa estimula uma cultura de aprendizagem, criação ou compartilhamento do conhecimento com seus funcionários e fornecedores? Como esta foi constituída?

R: Sim, a empresa estimula esta cultura, principalmente pelo fato desta estar embutida dentro do conceito de parcerias que envolvem tanto fornecedores como funcionários. No aprendizado a empresa está sempre buscando as melhores práticas desenvolvidas, juntamente com as oportunidades de aplicá- las.

Obs.: Este estímulo independe de investimentos, pois a empresa busca aproveitar o máximo as competências e o potencial de seus funcionários e fornecedores.

6. A empresa utiliza-se de ferramentas para facilitar o processo de geração e disseminação do conhecimento com seus funcionários e fornecedores? Quais?

R: Sim, a empresa utiliza-se de várias ferramentas neste sentido, como: instrumentos de comunicação, Gráfico de Pareto, diagrama de causa e efeito e Poka-Yoke.

\section{Comprometimento}

5. A empresa conta com a colaboração de seus funcionários e fornecedores em eventuais necessidades, tais como horas extras, etc.?

R: Sim, existe uma cumplicidade entre fornecedores e funcionários, por mais variados que sejam os problemas.

6. A empresa conta com a colaboração de seus funcionários e fornecedores para o alerta de eventuais problemas durante o processo produtivo e qualidade dos produtos?

R: A empresa conta com a colaboração dos funcionários e dos fornecedores dentro da concepção de parcerias. A ajuda necessita ser mútua.

\section{Relacionamento}

15. Como você considera o relacionamento da empresa com seus funcionários e fornecedores?

$\mathrm{R}$ : É um relacionamento de parcerias, sempre com todos trabalhando em prol de um mesmo objetivo, atender os volumes de produção com a qualidade necessária. A empresa conta com um total de 110 fornecedores, porém um mesmo fornecedor poder fornecer vários itens a empresa.

16. O relacionamento entre os setores da empresa está dentro das expectativas? R: Não totalmente, porém o importante é que todos possuem consciência sobres de suas obrigações e ponderações em relação ao produto final. Seria importante mensurar este relacionamento.

17. A média salarial aplicada pela empresa está acima da média paga pelo mercado? 
R: Sim, hoje está, com algumas raras exceções em que a empresa já está buscando acertar.

18. A empresa reconhece os serviços prestados por seus funcionários e fornecedores? De que forma esse reconhecimento é transmitido?

R: Sim, a empresa reconhece os serviços prestados por seus funcionário e fornecedores, oficialmente por meio de cartas e eventos específicos como o programa de reconhecimento, porém a empresa utiliza-se também do reconhecimento face a face.

19. A empresa adquire uma cota mínima de produtos de seus fornecedores?

R: Sim, através de contratos conhecidos como (Relising). Existe uma programação de quatro semanas de antecedência com os fornecedores para este conseguir prover a demanda.

20. Na busca de novos projetos a empresa procura, na maioria das vezes, seus fornecedores já conhecidos? Por quê?

$\mathrm{R}$ : Sim, principalmente os que enfatizam o sistema de parcerias diminuindo desta forma significativamente os custos. Os "fornecedores problemas" para a empresa são trabalhados para se retirarem ou saírem da parceria. A empresa possui 110 fornecedores.

21. A empresa procura realizar as transações com seus fornecedores através de contratos formais?

R: Sem dúvida, o objetivo é garantir os direitos e deveres de ambos os lados, independentemente do grau de parcerias.

\section{Custos}

7. Na eventualidade de fabricação de novos produtos a empresa oferece treinamentos adequados aos seus funcionários e fornecedores?

R: Sim, é uma necessidade para a continuidade do processo.

8. A empresa utiliza alguma política de redução de custos? Qual? Ela tem se mostrado eficiente?

R: Sim, existe uma política de redução de custos na empresa, através da otimização de processos, o que aumenta a produtividade juntamente com o aumento da sinergia e oportunidades de melhorias. É importante destacar que estas políticas têm se mostrado eficiente através da utilização de ferramentas como os PMC e geração de idéias.

9. Os custos de desenvolvimento de novos produtos são repassados ou compartilhados com seus fornecedores?

R: Sim, pois já estão dentro da concepção e cultura de parcerias, onde o estreitamento das relações é profundo e não apenas relações superficiais. É importante destacar que os contratos são separados ou preparados de acordo com as necessidades da empresa.

\section{Responsabilidade}

7. A responsabilidade de eventuais falhas no processo é compartilhada por todos os envolvidos (funcionários e fornecedores)? 
R: Para a identificação e resolução da falhas sim, porém a partir daí procura-se identificar o responsável ou responsáveis, juntamente com os custos causados por estes problemas.

8. A empresa entrega seus produtos dentro dos prazos estabelecidos às plantas da organização?

R: Esta é um a busca contínua da empresa e também o seu principal compromisso

9. A empresa se preocupa com a integridade e saúde de seus funcionários? De que forma?

R: Sim, através de campanhas educativas, diálogos de seguranças e a aquisição de novos equipamentos.

\section{Informação}

7. A empresa comunica suas estratégias e resultados aos funcionários e fornecedores? Como?

R: Sim. Aos funcionários de uma forma mais ampla trimestralmente. Já aos fornecedores através de reuniões semanais e o dia da qualidade, muitas vezes com a participação destes. E ainda utiliza-se Workshop.

8. A empresa comunica de forma clara suas expectativas sobres seus funcionários e fornecedores?

R: Sim, ela comunica. Porém, a eficiência desta comunicação pode ser melhorada.

9. As ferramentas utilizadas pela empresa para informar funcionários e fornecedores são eficientes? Quais são?

R: Sim. A empresa utiliza-se de quadros de aviso, sistema oito passos e o comunicado executivo. Já para os fornecedores o Helpline e o sistema RI (relatórios de inspeção).

\section{Qualidade}

5. As peças recebidas na empresa possuem certificados de qualidade de seus fornecedores?

$\mathrm{R}$ : Sim, todas as peças são certificadas antes mesmo dos fornecedores começarem a fornecê-las.

6. Nos últimos anos os indicadores de qualidade da empresa melhoraram? Por quais motivos?

R: Sim, principalmente por conta das parcerias desenvolvidas com os fornecedores e um foco maior nos processos internos e externos.

\section{Imagem}

8. A marca da empresa é respeitada no mercado?

R: Sem dúvida, recentemente a empresa foi avaliada pela Top of mid, como a primeira montadora de veículos na mente dos consumidores, este fato ocorre a exatamente 15 anos consecutivos.

9. A empresa possui uma boa imagem no mercado?

R: Sem dúvida, a marca está associada à durabilidade, praticidade e robustez. 
10. As parcerias formadas pela empresa têm se mostrado importante no mercado?

R: Sim, com certeza, e a cada dia novas parcerias são buscadas.

11. Considerações finais ou observações do entrevistado?

R: O foco principal hoje para a empresa é a questão da formação de parcerias.

Data: 27 / 02 / 2006

Hora início: 10 / 20 / 00

Hora término: 10 / 54 / 00 